EVALUASI FUNGSI FISIK DAN TOLERANSI POHON TEPI JALAN TERHADAP POLUSI UDARA DI LINGKAR LUAR KEBUN RAYA BOGOR

ANDREA MUSTIKA FEBRIANTI

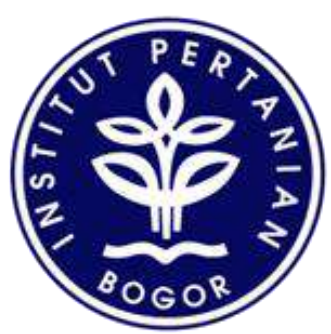

DEPARTEMEN ARSITEKTUR LANSKAP

FAKULTAS PERTANIAN

INSTITUT PERTANIAN BOGOR

BOGOR

2019 


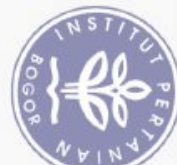

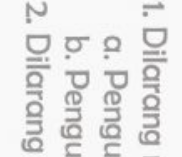

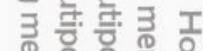

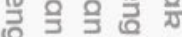

흥흘동 응

政放。

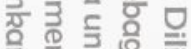

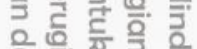

응 此

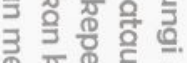

罗敢

을

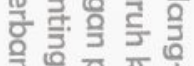

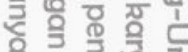

중 흥 옹

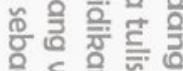

을. है ? ज

을 윰

욷 $\overline{0}$ 晋

웅

들 훌

을 을

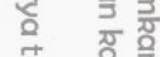

高

包

음 훙 궁

ฏ 링

잉

芒 施

응 익

응 흥 뭉

ᄃ윽

일

용 울

촐 


\section{PERNYATAAN MENGENAI SKRIPSI DAN SUMBER INFORMASI SERTA PELIMPAHAN HAK CIPTA}

Dengan ini saya menyatakan bahwa skripsi berjudul Evaluasi Fungsi Fisik dan Toleransi Pohon Tepi Jalan terhadap Polusi Udara di Lingkar Luar Kebun Raya Bogor adalah benar karya saya dengan arahan dari komisi pembimbing dan belum diajukan dalam bentuk apapun kepada perguruan tinggi manapun. Sumber informasi yang berasal atau dikutip karya yang diterbitkan dari penulis lain telah disebutkan dalam teks dan dicantumkan dalam Daftar Pustaka di bagian akhir skripsi ini.

Dengan ini saya melimpahkan hak cipta dari karya tulis saya kepada Enstitut Pertanian Bogor.

Bogor, November 2019

Andrea Mustika Febrianti 


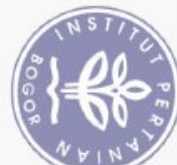

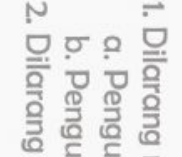

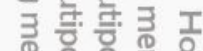

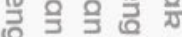

흥흘동 응

政放。

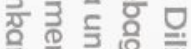

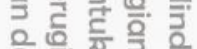

응 此

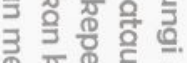

罗敢

을



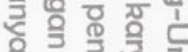

중 흥 옹

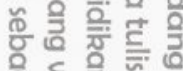

을. है ? ज

을 윰

욷 $\overline{0}$ 晋

웅

들 훌

을 을



高

包

음 훙 궁

ฏ 링

잉

芒 施

응 익

응 흥 뭉

ᄃ윽

일

용 울

촐 


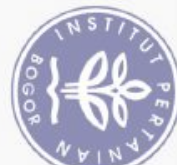

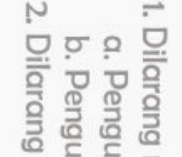

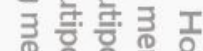

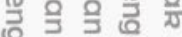

흥흘동 응

政放。

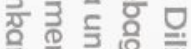

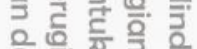

응 此

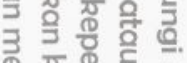

罗敢

을

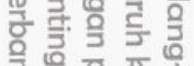

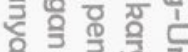

중 흥 옹

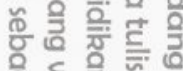

을. है ? ज

을 윰

욷 $\overline{0}$ 晋

웅

들 훌

을 을

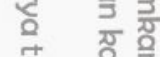

高

包

음 훙 궁

ฏ 링

잉

芒 施

응 익

응 흥 뭉

ᄃ윽

일

용 울

촐 
LEMBAR PENGESAHAN

Judul Penelitian

: Evaluasi Dungsi Fisik dan Toleransi Pohon Tepi Jalan terhadap Polusi Udara di Lingkar Kebun Raya Bogor

: Andrea Mustika Febrianti

trama

NIM

: A44150015

: Arsitektur Lanskap

Disetujui oleh

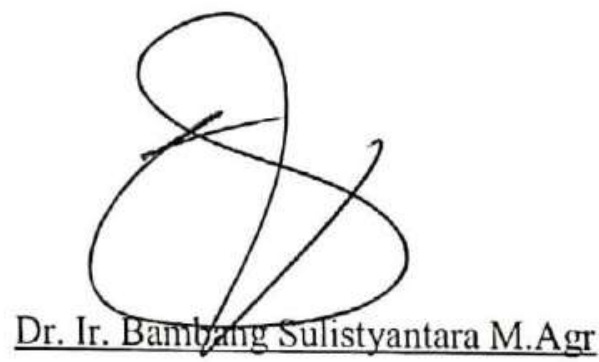

Pembimbing

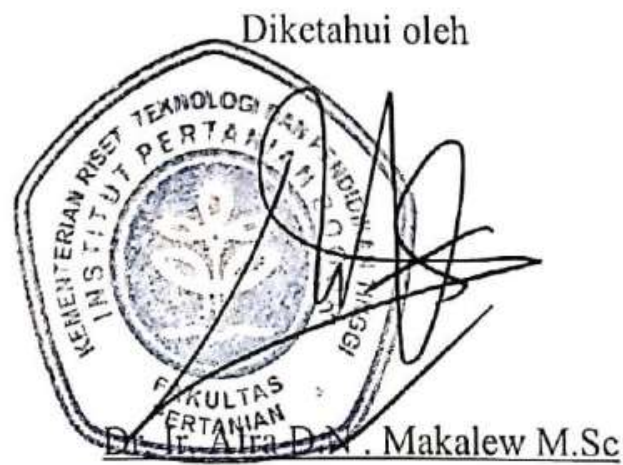

Ketua Departemen Arsitektur Lanskap

Tanggal disetujui : 20 DEC 2018 
을 뭉

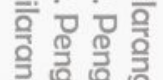

흔들 울

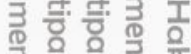



응을 훙

ङ

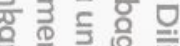

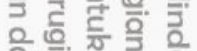

政品

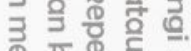

尔产

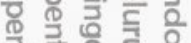

产言产吉

غ이일 일

눙 응 긍

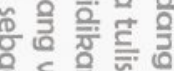

을. है ? ज

을 윽

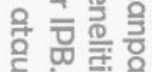

울

들 휼

运 突豆

ग ग 즁

高

ㅋ..를

을 흥코

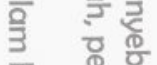

잉

空 总

융 일

응 흥 뭉

5 웅

일

용

촐 


\section{ABSTRAK}

ANDREA MUSTIKA FEBRIANTI. Evaluasi Fungsi Fisik dan Toleransi Pohon Tepi Jalan terhadap Polusi Udara di Lingkar Luar Kebun Raya Bogor. Dibimbing oleh BAMBANG SULISTYANTARA.

Lanskap jalan merupakan fasilitas penunjang untuk para pengendara motor. Aktifitas pada lanskap jalan tidak lepas dari penggunaan kendaraan. Pembakaran bahan bakar pada kendaraan menyebabkan terjadinya pencemaran udara karena menghasilkan zat pencemar udara. Pohon sebagai salah satu bagian lanskap jalan menjadi salah satu elemen ekologi yang penting untuk lingkungan dan măhluk hidup. Pohon yang ditanam ditanam di pinggir jalan atau yang biasa disebut pohon tepi jalan sebaiknya dapat mengakomodasi fungsi ekologi sebagai penyerap polusi. Sayangnya, tidak semua pohon sesuai sebagai pohon tepi jalan, salah șatu hal yang dapat dinilai kesesuaiannya ada fungsi fisik dan toleransi pohon terhadap zat polusi udara. Penelitian ini bertujuan untuk mengevaluasi kesesuăian fisik pohon dalam segi mennyerap polusi gas dan menjerap polusi partike serta toleransinya tehadap polusi udara. Metode yang digunakan adalah analisis deskriptif dengan membandingkan keadaan fungsi fisik pohon di lapangân dengan literatur yang tersedia, untuk pengukuran toleransi menggunakan metode Air Polution Tolerance Index (APTI). Diketahui dari data yang diperoleh, Lingkar Luar Kebun Raya Bogor zat polutan yang sudah diatas baku mutu ialah $\mathrm{Pb}$ dan $\mathrm{H}_{2} \mathrm{~S}$. Dari hasil penelitian ditemukan dari total populasi bahwa sebanyak $78,5 \%$ pohon sangat sesuai dalam sebagai penyerap polusi gas, sebanyak $4,2 \%$ sangat=sesuai sebagai penjerap polusi partikel dan $77,4 \%$ sesuai sebagi penjerap polusi partikel. Untuk tingkat toleransi sebanyak $62,3 \%$ memiliki tingkat toleransi sedangdan sebanyak 35,6\% memiliki tingkat toleransi sensitif.

Kata kunci : APTI, fungsi fisik, pohon tepi jalan, polusi udara 


\section{ABSTRACT}

ANDREA MUSTIKA FEBRIANTI. Evaluation of Physical Function and Tolerance Level of Road Side Tree in Bogor Botanical Garden's Surrounding. Supervised by BAMBANG SULISTYANTARA.

Streetscape is a supporting facility for motorcyclists. Activities on the road landscape are not separated from the use of vehicles. The combustion of fuel in vehicles causes air pollution because it produces air pollutants. Trees as one part of the road landscape become one of the essential ecological elements for the environment and living creatures. Planted trees planted on the roadside or दommonly called roadside trees should be able to accommodate ecological functions as pollution absorbent. Unfortunately, not all trees are suitable as a roadside tree, one of the things that can be assessed as a physical function and a tree tolerance to air pollution. The research aims to evaluate the physical suitability of the trees in terms of gas pollution and the pollution and the tolerance of the air pollution. The method used is a descriptive analysis by comparing the state of the physical functioning of trees in the field with available literature, for measurement of tolerance using the method of Air Polution Tolerance Index (APTI). Known from the data obtained, the outer circumference of Bogor botanical garden substances that have been above the quality is $\mathrm{Pb}$ and $\mathrm{H} 2 \mathrm{~S}$. From the results of the study found from the total population that as much as $78.5 \%$ of the trees are very suitable in the gas pollution absorber, as much as $4.2 \%$ are suitable as a particle polluter and $77.4 \%$ accordingly as the particle pollution. For a tolerance rate as much as $62.3 \%$ has a moderate tolerance level and as much as $35.6 \%$ has a level of sensitive tolerance.

Keywords : APTI, physical function, pollution, roadside tree 


\title{
EVALUASI FUNGSI FISIK DAN TOLERANSI POHON TEPI JALAN TERHADAP POLUSI UDARA DI LINGKAR LUAR KEBUN RAYA BOGOR
}

\author{
ANDREA MUSTIKA FEBRIANTI \\ Skripsi \\ sebagai salah satu syarat untuk memperoleh gelar \\ Sarjana Pertanian \\ pada \\ Departemen Arsitektur Lanskap
}

\author{
DEPARTEMEN ARSITEKTUR LANSKAP \\ FAKULTAS PERTANIAN \\ INSTITUT PERTANIAN BOGOR \\ 2019
}


을 뭉

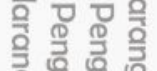

흔흘 을

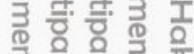

윽

홍흐릉 응

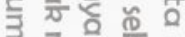

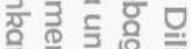

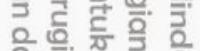

응 는

క

罗敢

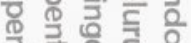

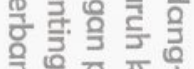



준 흥 홍



을. है ? ज

윽 을

윧 可产焉

울

들 휼

옥 을

ग ग ग्रू

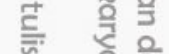

ㅋ.

을 흥 공

刍 夏

잉

壳 总

융 일

응 흥 윰

웅

올

항 울

촐 




Dilarang mengutip sebagian atau seluruh katya tulis ini tanpa mencantumkan atau menyebutkan sumbernya. Pengutipan hanya untuk kepentingan pendidikan, penelitian, penulisan karya ilmiah, penyusunan laporan, penulisan kritik, atau tinjauan suatu masalah; dan pengutipan tersebut tidak merugikan kepentingan

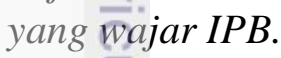

Dilarang mengumumkan dan memperbanyak sebagian atau seluruh karya tulis ini dalambentuk apa pun tanpa izin IPB. 


\section{PRAKATA}

Puji syukur dipanjatkan ke hadirat Allah SWT atas rahmat dan hidayahNya sehingga skripsi yang berjudul "Evaluasi Fisik dan Toleransi Pohon Tepi Jalan terhadap Polusi Udara di Lingkar Luar Kebun Raya Bogor" ini dapat terselesaikan. Skripsi ini merupakan syarat untuk memperoleh gelar sarjana di Departemen Arsitektur Lanskap, Fakultas Pertanian, Institut Pertanian Bogor. Penulis berterimakasih kepada pihak-pihak yang berjasa dalam pembuatan skripsi ini, yaitu kepada

1. Dr. Ir. Bambang Sulistyantara M.Agr selaku dosen pembimbing skripsi yang telah memberikan pengarahan dan saran dalam melakukan penelitian ini. Setiap bimbingan merupakan waktu yang berharga.

2. Pihak Dinas terkait yaitu Dinas Pertamanan, BAPPEDA, dan DLH Kota Bogor yang telah memberikan izin dan mendukung dalam melakukan penelitian ini.

3. Kedua orang tua penulis, yang selalu melimpahkan dalam kasih sayang dan doa.

4. Quenta, Ica, Afi, Kiasa, dan Fitri yang telah menemani penulis saat mengambil data di lapang. Terimakasih sudah memberi kenangan pada setiap jengkal di tapak penelitian.

5. Adit, Praja dan Habibah yang telah membantu dalam proses perizinan lab serta pengolahan data.

6. Oca, Ipeb, Seni, Aya, Vio, Nadine, Cencen, Astrid, Dwi, dan Fiha yang selalu bergantian menguatkan dalam doa dan usaha.

마. Truni dan Iduy yang telah membersamai dari penyusunan proposal hingga sidang dalam suka dan duka.

8. Teman-teman ARL 52 yang selalu ada. Terimakasih atas segala kenangan dan cintanya.

9. Teman-teman ARL 50, ARL 51, ARL 53, dan ARL 54 yang telah membantu dan selalu menyemangati penulis.

Penulis berharap penelitian ini dapat menjadi manfaat untuk berbagai pihak dan kalangan yang memerlukan referensi penelitian yang akan datang.

Bogor, November 2019

Andrea Mustika Febrianti 


\section{DAFTAR ISI}

DAFTAR TABEL $\quad$ xi

DAFTAR GAMBAR $\quad$ xi

PENDAHULUAN 1

Latar Belakang 1

Tujuan 2

Manfaat 2

Kerangka Pikir $\quad 3$

TINJAUAN PUSTAKA 5

Lanskap Jalan $\quad 5$

Pencemaran Udara

Karakteristik Emisi Gas Buang 6

Jalui Hijau Jalan 6

Fungsi Pohon sebagai Penyerap Polusi $\quad 7$

Air Pollution Tolerance Index (APTI)

METODOLOGI

Lokầsi dan Waktu Penelitian

Alat dan Bahan $\quad 8$

Batäsan Penelitian 9

Metōde Penelitian 9

HASIE DAN PEMBAHASAN 20

Kondisi Umum Jalur Hijau 26

Evałuasi Fisik Pohon sebagai Penyerap dan Penjerap Polusi 32

Rekomendasi $\quad 45$

SIMPÖLAN DAN SARAN

Simpulan $\quad 47$

Saran $\quad 48$

DAFTAR PUSTAKA 49

LAMPIRAN

RIWAYAT PENULIS 


\section{DAFTAR TABEL}

$\begin{array}{lll}\text { Tabel } 1 & \text { Rician alat yang digunakan } & 8\end{array}$

$\begin{array}{llr}\text { Tabel } 2 \text { Bahan-bahan yang digunakan } & 9\end{array}$

Tabel 3 Jenis data inventarisasi 11

$\begin{array}{lll}\text { Tabel } 4 & \text { Kriteria fungsi ekologi } & 12\end{array}$

$\begin{array}{lll}\text { Tabel } 5 & \text { Klasifikasi tanaman berdasarkan nilai toleransinya } & 18\end{array}$

Tabel $6 \quad$ Pembobotan nilai evaluasi fisik dengan toleransi 19

Tabel 7 Perbandingan volume dan rata-rata kendaraan sebelum dan

Sesudah penerapan SSA 22

Tabel $8 \quad$ Keadan ambien di TUgu Kujang tahun 2015-2018 24

Tabel 9 Jenis dan jumlah pohon pada Jl. Pajajran 28

Thabel $10 \quad$ Jenis dan jumlah pohon pada Jl. Otto Iskandardinata 29

Tabel 11 Jenis dan jumlah pohon pada Jl. Juanda 30

Tabel 12 Jenis dan jumlah pohon pada Jl. Jalak Harupat 32

Fabel 13 Daftar persentase kesesuaian pohon penjerap polusi gas $\quad 32$

Tabel 14 Daftar persentase kesesuaian pohon penjerap polusi partikel 33

Tabel 15 Kandungan asam askorbat, total klorofil, pH, dan kadar air

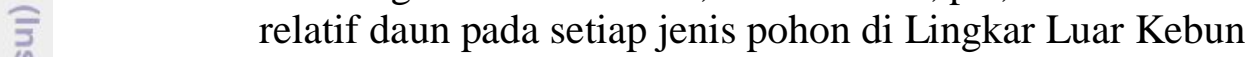

Raya Bogor 35

Fabel 16 Toleransi Tanaman terhadap pencemaran udara berdasarkan

nilai APTI

Tabel 17 Hubungan fungsi fisik pohon sebagai penyerap gas dengan

toleransi terhadap polusi udara 40

Pabel 18 Hubungan fungsi fisik pohon sebagai penjerap partikel dengan

Tabel 19

toleransi terhadap polusi udara

Hubungan aspek evaluasi pohon terhadap polusi udara $\quad 44$

Tabel 20

Rekomendasi tanaman toleran polusi udara

\section{DAFTAR GAMBAR}

Gambar 1 Kerangka pikir penelitian 4

$\begin{array}{ll}\text { Gambar } 2 \text { Lokasi penelitian } & 8\end{array}$

$\begin{array}{ll}\text { Gambar } 3 & \text { Letak jalur hijau } \\ & 10\end{array}$

Gambar 4 Ilustrasi persentase total cahaya yang diblokir oleh pepohonan klasifikasi kerapatan tajuk pohon 13

Gambar 5 Ilustrasi persentase total cahaya yang diblokir oleh pepohonan klasifikasi kerapatan tajuk pohon 14

Gambar $6 \quad$ Klasifikasi tekstur batang 15

Gambar 7 Metode pengambilan sampel daun 16

Gambar $8 \quad$ Persentase jenis kendaraan bermotor di Kota Bogor $2016 \quad 21$

Gambar $9 \quad$ Jumlah STNK yang dikeluarkan Samsat Kota Bogor $2017 \quad 21$

Gambar 10 Arah sirkulasi sebelum dan sesudah penerapan SSA 22

Gambar 11 Diagram emisi kendaraan bermotor berbahan bakar bensin dan solar di Kota Bogor

Gambar 13 Kandungan udara ambien $\mathrm{H}_{2} \mathrm{~S}$ pada tahun 2015-2018

Gambar 14 Pembagian segmen jalan Lingkar Luar Kebun Raya Bogor 27 
$\begin{array}{lll}\text { Gambar } 15 & \text { Bentuk potongan Jl. Pajajran } & 27\end{array}$

Gambar 16 Bentuk potongan J1. Otto Iskandardinata 29

Gambar 17 Bentuk potongan Jl. Juanda 30

Gambar 18 Bentuk potongan Jl. Jalak Harupat 31

$\begin{array}{lll}\text { Gambar } 19 & \text { Spot hitam gejala kerusakan daun angsana } & 39\end{array}$

$\begin{array}{lll}\text { Gambar } 20 & \begin{array}{l}\text { Nekrosis yang terjadi pada percobaan sema } \\ \text { kategori sensitive pada tingkat polusi yang berbeda }\end{array}\end{array}$

\section{DAFTAR LAMPIRAN}

Lampi⿶ãan 1 Jenis, letak dan jumlah pohon pada Lingkar Luar Kebun Raya Bogor 53

Lampizan 2 Skor Key Performance Index pohon terhadap polusi gas 53

Lampiran 3 Skor Key Performance Index pohon terhadap polusi partikel 54

Lampiran 4 Proses pengambilan sampel 55

Lampiřan 5 Dokumentasi di Laboratorium

$\begin{array}{lll}\text { Lampiran } 6 & \text { Foto sampel daun } & 57\end{array}$

$\begin{array}{lll}\text { Lampiran } 7 & \text { Lembar pengujian zat klorofil } & 58\end{array}$ 


\section{PENDAHULUAN}

\section{Latar Belakang}

Secara geografis Kota Bogor terletak di antara 106' 48' BT dan 6' 26' LS, kedudukan geografis Kota Bogor di tengah-tengah wilayah Kabupaten Bogor serta lokasinya sangat dekat dengan Ibukota Negara, merupakan potensi yang strategis bagi perkembangan dan pertumbuhan ekonomi dan jasa, pusat kegiatan nasional untuk industri, perdagangan, transportasi, komunikasi, dan pariwisata. (BPLH, 2015). Kota Bogor menjadi salah satu akses utama menuju ke Kota Takarta, oleh karena itu banyaknya volume kendaraan yang melintasi jalan-jalan di Kota Bogor memberikan dampak baik positif yaitu pertumbuhan perekonomian kota melaju pesat, maupun dampak negatif yaitu ketidakteraturan transportasi yang diakibatkan jumlah kendaraan meningkat tiap tahunnya, pada tahun 2013 kendaraan bermotor di Kota Bogor berjumlah 357.102 unit, dan pada tahun 2014 meningkat menjadi 435.784 unit (DLLAJ, 2015). Penggunaan BBM yang

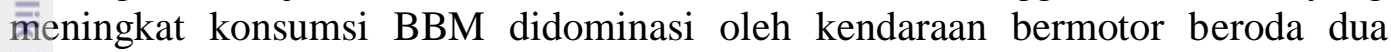
(sepeda motor) yang mencapai lebih dari 75\% (DLLAJ, 2015) memberikan efek meningkatnya emisi polusi udara, peningkatan suhu perkotaan akibat efek rumah kaca. kaca.

Pencemaran udara merupakan peristiwa dimana masuknya bahan-bahan pencemar ke udara yang dampaknya mengakibatkan gangguan dan ketidaknyamanan terhadap mahkluk hidup, dan juga terjadinya kerusakan terhadap lingkungan. Peraturan Pemerintah Republik Indonesia nomor 41 tahun 599 yang berisi tentang Pengendalian Pencemaran Udara menjelaskan mengenai strategi pemerintah dalam upaya perlindungan mutu udara dengan melakukan pengawasan terhadap segala jenis usaha atau kegiatan yang mengeluarkan bahan pencemar ke udara yang menyebabkan udara tidak dapat berfungsi sebagaimana mestinya (Depkes, 2012). Polusi udara yang terus meningkat dan menyebabkan penurunan kualitas udara dapat dijadikan sebagai indikator menurunnya kualitas lingkungan yang berdampak terhadap penurunan derajat kesehatan pengguna jalan, petugas jalan, dan masyarakat yang bermukim di sekitar jalan (PT. Jasa Marga Cabang CTC, 2011a). Polusi udara seperti partikel-partikel halus serta gas nitrogen oksida merupakan masalah lingkungan yang penting untuk dipecahkan, karena memberi dampak negatif terhadap kesehatan, proverty dan ekosistem. Resiko polusi banyak dipublikasikan oleh peneliti termasuk resiko kanker darah, tetapi jarang disadari bahwa banyak warga kota meninggal karena infeksi saluran pernapasan, asma, dan kanker paru-paru yang disebabkan oleh polusi partikel.

Ruang terbuka hijau (RTH) merupakan suatu lahan/kawasan yang mengandung unsur dan struktur alami yang dapat menjalankan proses-proses ekologis, seperti pengendalian pencemaran udara, ameliorasi iklim, pengendali tata air, dan sebagainya. Keberadaan ruang terbuka hijau sebagai kawasan yang dajpat menyokong lingkungan sekitar mutlak diperlukan karena besarnya manfaat yang dapat diberikan kepada masyarakat dalam menyokong kualitas dan kuantitas Fingkungan di dalam perkotaan. Salah satu bentuk RTH yang sering ditemui yaitu jalur hijau jalan. Jalur hijau jalan dapat berperan mengurangi polusi akibat emisi kendaraan yang berbentuk gas pencemar serta partikel padat dengan menanam tanaman sepanjang jalur jalan. 
Pemilihan jenis tanaman yang ditanam pada jalur hijau jalan harus sesuai dengan fungsi yang diinginkan. Selain fungsi tanaman sebagai estetika, tanaman juga harus mempunyai fungsi ekologis untuk meningkatkan kualitas udara salah satunya dengan menyerap polutan dalam bentuk gas atau partikel. Setiap spesies memiliki respon yang berbeda terhadap polusi udara. Beberapa spesies ada yang sensitif ataupun yang toleran. Spesies sensitif dapat digunakan sebagai indikator awal adanya polusi, sedangkan spesies yang toleran dapat membantu mengurangi beban pencemaran (Sing dan Rao, 1983). Penyeleksian spesies yang sensitif dan toleran terhadap polusi udara sangatlah penting untuk dilakukan. Parameter toleransi tanaman dapat dihitung dengan APTI (Air Pollution Tolerance Index) (Sing dan Rao, 1983). Evaluasi nilai APTI pada beberapa spesies tanaman bertujūan untuk menetapkan kepekaan spesies tanaman yang kemudian dapat digunakan untuk memilih tanaman yang memiliki toleransi terhadap polusi udara. Berdasarkan nilai APTI yang diperoleh serta karakter biologis dan sosioekonomi maka nnilai API (Anticipated Performance Index) dari spesies tanaman dapat ditentukan nilainya (Tripathi et al. 2007).

Jalan-Jalan Lingkar Luar Kebun Raya merupakan beberapa dari jalan arteri $\overline{\bar{y}}$ ang berada di Kota Bogor. Jalan Lingkar Luar Kebun Raya terdiri atas Jl. Pajajran, Jl. Otto Iskandardinata, Jl. Juanda, dan Jl. Jalak Harupat. Padatnya kendarăan di jalan-jalan ini mengindikasikan adanya pencemaran udara. Salah satu upaya yang dilakukan pemerintah Kota Bogor untuk mereduksi pencemaran udara adalah membuat jalur hijau jalan disepanjang lingkar luar Kebun Raya Bogorô Oleh karena itu, diperlukan penelitian lebih lanjut untuk mengetahui kesesuaian pemilihan tanaman pada jalur hijau Jalan Lingkar Luar Kebun Raya Bogor॰ untuk menyerap polusi berdasarkan karakter fisik serta tingkat toleransi tanaman pada polusi udara.

\section{Tujuan}

Tujuan Penelitian ini adalah sebagai berikut:

1. Mengetahui kondisi ambien di jalur pedestrian lingkar luar Kebun Raya Bogor

2. Mengevaluasi kesesuaian karakter fisik pohon sebagai penyerap polusi

3. Menilai APTI (Air Pollution Tolerance Index) dan API (Anticipated Performance Index) pada pohon di jalur hijau Lingkar Luar Kebun Raya Bogor

4. Memberikan rekomendasi pohon yang sesuai sebagai penyerap polusi
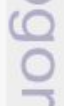

\section{Manfaat}

Hasil Penelitian ini diharapkan dapat bermanfaat sebagai berikut:

1. Memberikan informasi dan gambaran kepada akademisi, pengelola సkawasan, pemerintah ataupun pihak lain yang membutuhkan untuk -memperkaya wawasan tentang polusi yang ada di Kota Bogor

2. Menumbuhkan kesadaran masyarakat dan pengelola kawasan mengenai pentingnya peran pohon sebagai alat memperbaiki keadaan lingkungan 
3. Memberi rekomendasi bagi pengelola atau stakeholder sebagai bahan pertimbangan atau dasar acuan dalam penataan jalur hijau yang mengunakan pohon dalam bioindikator

\section{Kerangka Pikir}

Perencanaan jalur hijau tepi jalan sudah diaplikasikan di Kota Bogor, salah satu contohnya berada di Jalan Lingkas Luar Kebun Raya Bogor. Pemilihan vegetasi sebagai tanaman tepi jalan perlu diperhatikan agar dapat memenuhi fungsi ekologisnya. Salah satu jenis vegetasi yang penting adalah pohon. Pohon memiliki kemampuan ekologis salah satunya sebagai penyerap polusi. Perlu diketahui perubahan sistem transportasi di Kota Bogor mengakibatkan


meningkat. Maka perlu dilakukan kajian mengenai kesesuaian fungsi pohon epi jẩlan sebagai agen penyerap polusi. Salah satu cara yang dilakukan adalah evaluasi fisik pohon dan evaluasi nilai toleransi pohon terhadap polusi. Diharapkan hasil penelitian ini bisa berguna menjadi bahan untuk pemilihan pohon tepi jalan yang dapat menjadi agen penyerap polusi yang baik. Kerangka piker disajikan pada gambar 1 di halaman selanjutnya. 

Jakarta

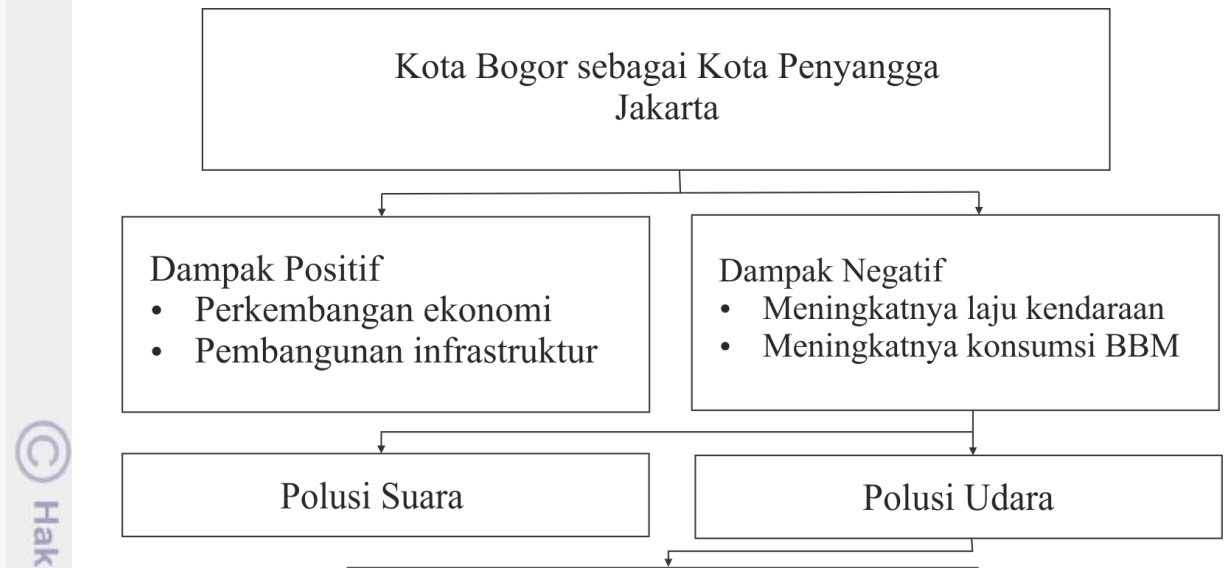
upaya mengurangi polusi udara

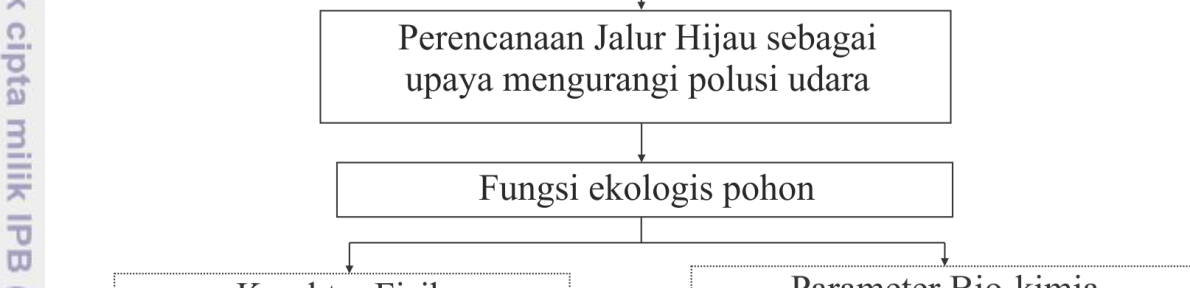

)

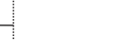

Karakter Fisik

Kritêria :

1. Bêrdaun tipis

2. Bërdaun banyak

3. Këpadatan tajuk

W
$\circ$
$\stackrel{\circ}{\circ}$
Menjerap polusi partikel

Kriteria :

1. Berdaun jarum/ berbulu

2. Berdaun Lebar

3. Tekstur batang kasar/berduri

4. Kepadatan tajuk

5. Kepadatan ranting
Evaluasi Toleransi pohon terhadap polusi

Parameter :

1. Kandungan air relatif

2. $\mathrm{pH}$

3. Kandungan asam askorbat

4. Kandungan klorofil

Evaluasi Indeks antisipasi kinerja pohon berdasarkan manfaat bio-sosio-ekonomi

Rekomendasi pohon tepi jalan sebagai agen penyerap dan penjerap polusi

Gambar 1. Kerangka Pikir Penelitian 


\section{TINJAUAN PUSTAKA}

\section{Lanskap Jalan}

Lanskap kehidupan manusia tersusun atas jalan dan tempat, dimana jalan berfungsi sebagai jalur pergerakan orang dan kenderaan serta tempat sebagai pusat aktivitas dimana orang bekerja, berdagang, belajar, beribadah dan bersantai (Simonds, 1983). Jalan sebagai jalur pergerakan merupakan suatu kesatuan secara keseluruhan, seharusnya bersifat lengkap, aman, efisien serta dapat berfungsi sebagai jalur sirkulasi dan penghubung. Jalan dibagi tiga bagian berdasarkan peruntukkannya yaitu sirkulasi kenderaan bermotor, sirkulasi sepeda, dan sirkulasi pejalan kaki.

Lanskap jalan adalah wajah dari karakter lahan atau tapak yang terbentuk pada lingkungan jalan, baik yang terbentuk dari elemen lanskap alamiah seperti bentuk topografi lahan yang mempunyai panorama yang indah, maupun yang terbentuk dari elemen lanskap buatan manusia yang disesuaikan dengan kondisi ląhannya. Lanskap jalan ini mempunyai ciri-ciri khas karena harus disesuaikan dengan persyaratan geometrik jalan dan diperuntukkan terutama bagi kenyamanan pemakai jalan serta diusahakan untuk menciptakan lingkungan jalan yang indah, teyaman dan memenuhi fungsi keamanan. (PERMEN PU 05/2008)

Klasifikasi jalan menurut Harris dan Dines (1988) adalah sistem jalan tol (freeway system), sistem jalan arteri primer (major arterial system), sistem jalan kolektor (collector street system) serta sistem jalan lokal (local street system). Menurut Simonds (1983), lanskap jalan berperan penting dalam membangun Karakter lingkungan, spasial, dan visual agar dapat memberikan suatu identitas perkotaan. Suatu perencanaan lanskap jalan harus memberi kesan yang menyenangkan dan setiap pergerakan akan berguna bagi pemakai bila terdapat keharmonisan dan kesatuan dengan karakteristik lanskap yang ada dan menghasilkan secara fisik fungsional dan secara visual estetika.

Menurut Booth (1983), lanskap jalan berfungsi untuk mendukung penggunaan secara terus-menerus, membimbing, mengatur irama pergerakan, mengatur waktu istirahat, mendefinisikan penggunaan lahan, memberikan pengaruh, mempersatukan ruang, membentuk lingkungan, membentuk karakter lingkungan, membangun karakter spasial, dan membangun visual. Harris dan Dines (1988) menjelaskan bahwa adanya jalan atau sirkulasi kendaraan di jalan raya mengakomodasikan tiga tujuan utama yaitu menyediakan akses untuk masuk ke suatu lahan dan bangunan, menghubungkan antar tata guna lahan yang ada, dan menyediakan jalur pergerakan untuk orang dan barang. Jalan juga harus dapat mengakomodasi kebutuhan pengguna jalan antara lain, jalur kendaraan bermotor, sirkulasi pengguna (user), serta sarana pendukung jalan.

\section{Pencemaran Udara}

Pencemaran lingkungan merupakan perubahan suatu lingkungan oleh proses alam atau kegiatan manusia yang menyebabkan kualitas lingkungan menurun sehingga tidak sesuai lagi dengan fungsinya. Terjadinya pencemaran lingkungan ini sebagian besar disebabkan oleh kegiatan manusia, perkembangan 
ekonomi, peningkatan populasi penduduk dan tingginya jumlah alat transportasi di kota-kota besar saat ini. (Wagh et al., 2006)

Menurut Keputusan Menteri Negara Kependudukan dan Lingkungan Hidup No. 2 Tahun 1988, pencemaran udara adalah masuk atau dimasukkannya makhluk hidup, zat, energi dan atau komponen lain ke udara dan atau berubahnya tatanan udara oleh kegiatan manusia atau oleh proses alam, sehingga kualitas udara turun sampai ke tingkat tertentu yang menyebabkan udara menjadi kurang atau tidak dapat berfungsi lagi sesuai dengan peruntukkannya. Sementara menurut Wardhana (2001), pencemaran udara dapat diartikan sebagai adanya bahan-bahan atau zat-zat asing di dalam udara yang menyebabkan perubahan susunan (kompösisi) udara dari keadaan normalnya. Menurut PP No. 41 Tahun 1999, pencemaran udara adalah masuknya atau dimasukkannya zat, energi, dari komponen lain ke dalam udara ambien oleh kegiatan manusia, sehingga mutu udara furun sampai ke tingkat tertentu yang menyebabkan udara ambien tidak dapat memenuhi fungsinya. Peraturan Pemerintah Republik Indonesia nomor 41 tahun 7999 yang berisi tentang Pengendalian Pencemaran Udara menjelaskan mengenai strategi pemerintah dalam upaya perlindungan mutu udara dengan melakūkan pengawasan terhadap segala jenis usaha atau kegiatan yang mengefuarkan bahan pencemar ke udara yang menyebabkan udara tidak dapat berfungsi sebagaimana mestinya (Depkes, 2012).

\section{Karakteristik Emisi Gas Buang}

Simonds (1978) mengemukakan bahwa sebagian besar polusi disebabkan oleh manusia, terutama dari pembakaran bahan bakar fosil di rumah, pabrik, dan kendaraan bermotor. Wardhana (2001) menjelaskan sebagian besar zat pencemar udara, Jyaitu sebanyak $75 \%$, berasal dari gas buangan hasil pembakaran bahan bakar fosil. Sementara sumber pencemaran di daerah perkotaan kebanyakan berasal dari kendaraan bermotor yaitu sebesar 80\%-90\% (Biro Bina Lingkungan Hidup DKI Jakarta, 1994)

\section{Jalur Hijau Jalan}

Menurut Peraturan Menteri Pekerjaan Umum No. 5 Tahun 2008, jalur hijau adalah jalur penempatan tanaman serta elemen lanskap lainnya yang terletak di dalam ruang milik jalan (RUMIJA) maupun di dalam ruang pengawasan jalan (RUWASJA). Menurut DPU (1996), penanaman di tepi jalan bertujuan untuk memisahkan pejalan kaki dari jalan raya dengan alasan keselamatan dan kenyamanan, memberikan ruang bagi utilitas dan perlengkapan jalan, baik yang terletak di atas maupun di bawah permukaan tanah, dan untuk kepentingan penanaman pohon tepi jalan.

Arifin N. (1993) mengemukakan bahwa jalur hijau berperan sebagai unsur pengisi sistem ekologi dan elemen yang dapat memperindah tampilan suatu lanskap serta memenuhi kebutuhan jasmani dan rohani manusia. Jalur hijau jalan juga dapat menjadi transportation corridors yang umumnya sama seperti jalur hijau tainnya, seperti di sepanjang jalan bebas hambatan, sepanjang rel kereta api, dan sepanjang aliran sungai. Menurut Fakultas Kehutanan IPB (1987) jalur hijau jalan dibangun untuk tujuan ameliorasi iklim, peredam kebisingan, debu dan bau, 
dengan tingkat intensitas pengelolaan dalam kategori "sedang", jenis tanaman yang dikembangkan dapat dari berbagai habitus (perdu, semak dan pohon).

\section{Fungsi Pohon sebagai Penyerap Polusi}

Menurut Grey dan Deneke (1978), tanaman dapat mengurangi polutan udara dengan proses oksigenisasi. Tanaman menghasilkan oksigen, sehingga polutan udara yang melewati sekitar tanaman akan mengalami proses pencampuran antara oksigen dengan polutan sehingga membuat udara di sekitar tanaman menjadi bersih. Tanaman merupakan penyaring udara yang mampu menyerap gas polutan seperti $\mathrm{SO}_{2}$ dan $\mathrm{HF}$ serta polutan lain di udara dalam Jumlah tertentu tanpa memperlihatkan efek kerusakan. Kaule (2000) ̄̄nengemukakan bahwa faktor-faktor yang berpengaruh terhadap potensi reduksi zat pencemar dan umur tanaman adalah jenis tanaman, kerimbunan dan ketinggian tạnaman, jumlah emisi karbon, suhu, kecepatan angin, kepadatan dan ketinggian bangunan.

Menurut Nurfaida, Dariati, dan Yanti (2011), mekanisme jalur hijau dalam mereduksi polusi udara terdiri dari: 1) adsorbsi, yaitu menjerap polusi hanya Sampai dipermukaan daun (menempel), khususnya polutan padat, partikel debu, dan logam-logam seperti $\mathrm{Pb}, \mathrm{Zn}$, dan $\mathrm{Fe}^{2}, 2$ ) absorbsi, yaitu menyerap polusi dengan cara mengasimilasi melalui jaringan tanaman di dalam daun, khusunya polusi berupa gas NOx, SOx, $\mathrm{CO}_{2}, \mathrm{CO}, \mathrm{HC}, \mathrm{PAN}$ (Peroxy Acetic Nitrat), 3) difusi, yaitu mengencerkan konsentrasi polutan, dan 4) deposisi, yaitu M̈enjatuhkan polutan ke tanah. Mekanisme ini memungkinkan dikuranginya jumlah debu yang melayang di udara.

\section{Air Pollution Tolerance Index (APTI)}

Setiap spesies memiliki respon yang berbeda terhadap polusi udara. Beberapa spesies ada yang sensitif ataupun yang toleran. APTI adalah salah satu metode untuk menentukan index toleransi suatu tanaman terhadap kondisi polusi udara. Kategori tanaman sensitif atau toleran ditentukan oleh beberapa parameter yaitu kandungan asam askorbat, kadar air relatif, kandungan klorofil, pH ekstrak daun, dan aktivitas peroksida asam askorbat (Sing dan Rao, 1983). Kerentanan jenis tanaman tergantung kepada karakteristik partikulat. Pengelompokkan tanaman ke dalam kelompok sensitif dan toleran dapat menjadi indikator polusi udara dan sebagai sink pengurangan polusi udara (Tripathi et al, 2007). Spesies sensitif dapat digunakan sebagai indikator awal adanya polusi, sedangkan spesies yang toleran dapat membantu mengurangi beban pencemaran (Sing dan Rao, 1983). Beberapa komponen pada tanaman seperti asam askorbat, klorofil, kadar air relatif, dan $\mathrm{pH}$ ekstrak daun terhadap toleransi polusi pada tanaman, parameter tersebut dihitung bersama dalam suatu formulasi untuk mendapatkan nilai empiris Cuntuk menandakan nilai APTI (Air Pollution Tolerance Index) (Sing dan Rao, 1983). 


\section{METODOLOGI}

\section{Lokasi dan Waktu Penelitian}

Penelitian dilaksanakan di jalur hijau jalan yang berlokasi di Jalan Pajajaran dan Jalan Jalak Harupat Kota Bogor, Provinsi Jawa Barat. Penelitian dilakukan pada bulan Maret - Juni 2019. Kegiatan yang dilakukan berupa pengumpulan data lapang, maupun pengumpulan data sekunder serta dilakukan pengolahan data. Penulisan dan penyusunan mulai dilakukan pada bulan Maret hingga Oktober 2019.

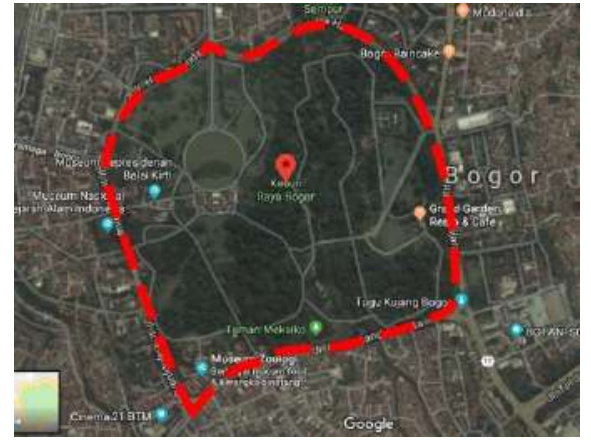

Gambar 2. Lokasi Penelitian Sumber : Google maps

\section{Alat dan Bahan}

-Penelitian ini memerlukan bahan dan alat dalam proses pengerjaanya. Alat yang digunakan dalam penelitian ini disajikan pada table 1, sedangkan bahan yang digunakan disajikan pada tabel 1 .

Tabel 1. Rincian alat yang digunakan

\begin{tabular}{|c|c|c|c|}
\hline No & Kegiatan & Alat & Kegunaan \\
\hline 1. & Uji klorofil & Spektrofometer & $\begin{array}{l}\text { Mengetahui absorbans } \\
\text { klorofil }\end{array}$ \\
\hline 2. & Uji keasaman & $\mathrm{pH}$ meter & $\begin{array}{l}\text { Mengetahui } \\
\text { keasaman }\end{array}$ \\
\hline 3. & Uji asam askorbat & Sentrifuge & Melarutkan larutan \\
\hline 4. & Uji kadar air & Oven & $\begin{array}{l}\text { Memanggang sampe } \\
\text { daun }\end{array}$ \\
\hline 5 . & Inventarisasi & GPS & $\begin{array}{l}\text { Menandai } \\
\text { pohon }\end{array}$ \\
\hline 6. & Eji APTI & Timbangan & Mengetahui berat sampel \\
\hline 7. & Dokumentasi & Kamera & Mengambil gambar \\
\hline 8. & Inventarisasi & Plastik & Menyimpan sampel \\
\hline 10. & Pengolahan data & Laptop & $\begin{array}{l}\text { Mengoprasikan berbaga } \\
\text { software }\end{array}$ \\
\hline 11. & Inventarisasi & Meteran gulung & Mengukur vegetasi \\
\hline 12. & Inventarisasi & Gunting pangkas & Mengambil sampel \\
\hline
\end{tabular}


Bahan yang dibutuhkan dalam penelitian ini merupakan keperluan data yang diperoleh dari survei langsung ke tapak maupun juga yang diperoleh dari instansi terkait, untuk lebih jelasnya disajikan pada Tabel 2.

Tabel 2. Bahan-bahan yang digunakan

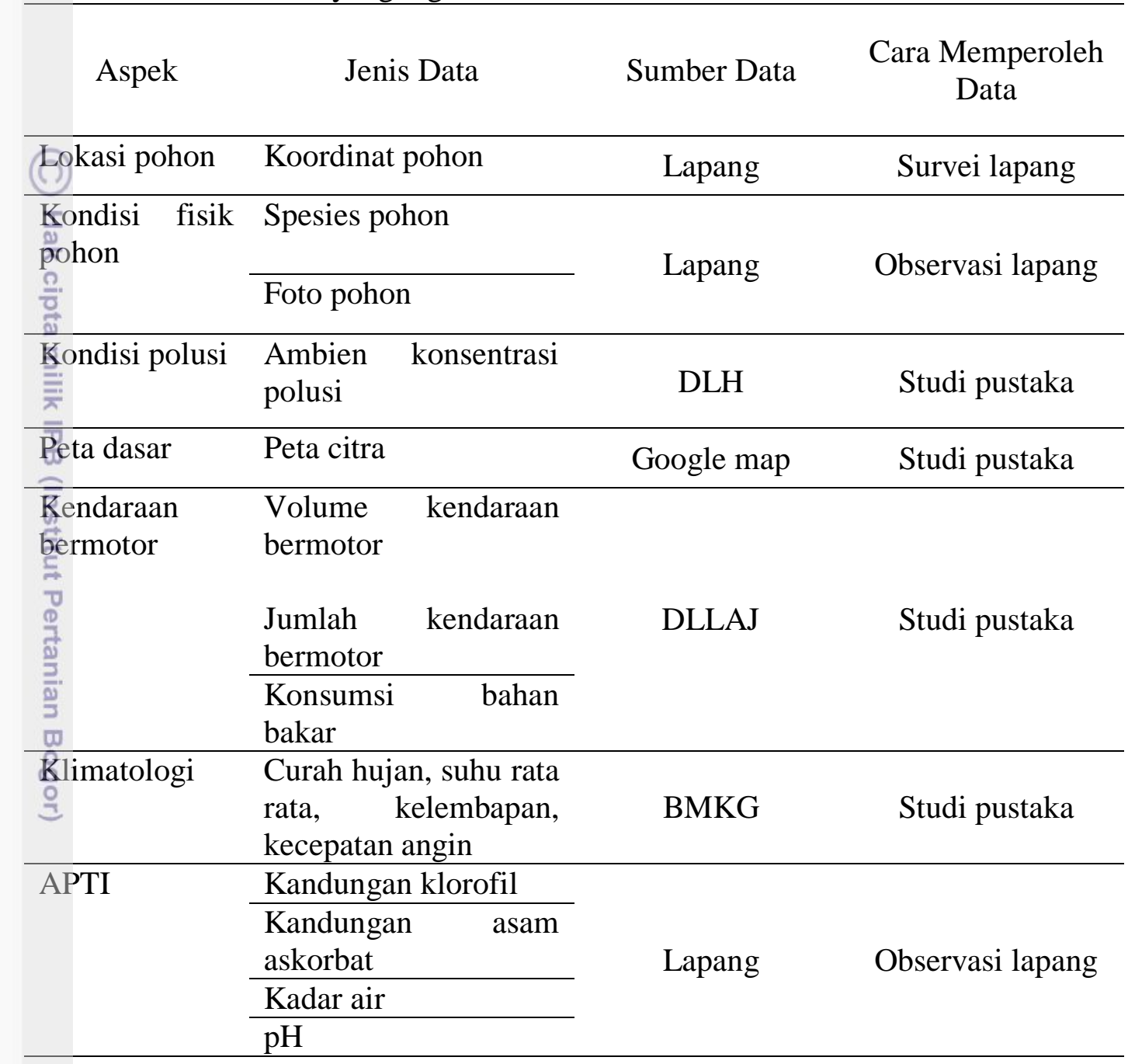

Batasan Penelitian

Batasan dalam penelitian ini adalah mengkaji kesesuaian fisik pohon dalam memberikan jasa lingkungan sebagai penyerap dan penjerap polusi udara di Dingkar Luar Kebun Raya Bogor, mengevaluasi nilai APTI dan API pada pohon di Lingkar Luar Kebun Raya, menentukan spesies pohon toleran polusi, dan membuat rekomendasi komposisi jalur hijau jalan yang dapat dijadikan sebagai masukan bagi pemerintah Kota Bogor.

\section{Metode Penelitian}

Metode yang digunakan dalam penelitian ini adalah metode deskriptif dan analisis spasial. Metode deskriptif digunakan dalam menganalisis dan menilai kondisi serta fungsi ekologis yang diteliti. Analisis spasial digunakan dalam pengolahan data spasial serta menspasialkan hasil penilaian. Penelitian terbagi menjadi tiga tahapan, yaitu inventarisasi, analisis, dan sintesis. Inventarisasi 
adalah pengambilan data secara primer dan sekunder. Datadata tersebut kemudian dianalisis untuk penyusunan sintesis. Sintesis dalam penelitian ini berupa perumusan rekomendasi yang bisa dijadikan bahan acuan untuk jalur hijau jalan.

\section{Tahap Perizinan}

Merupakan tahapan pembuatan surat izin yang terkait dengan keperluan pengambilan data seperti pada Pemerintah Kota Bogor yaitu Dinas Perumahan dan Pemukiman (Disperumkim) Kota Bogor, Badan Perencanaan dan Pembangunan Daerah (BAPPEDA) Kota Bogor, Dinas Lalu Lintas dan Angkutan Jalan (DLLAJ) Kota Bogor, dan Dinas Lingkungan Hidup (DLH) di Kota Bogor.

\section{Tahap Inventarisasi}

Đnventarisasi bertujuan untuk mengetahui kondisi umum pada jalur hijau jalan. Data inventarisasi dapat berupa data primer dan data sekunder. Data sekunđer diperoleh dari instansi terkait dan data primer diperoleh dari pengamatan

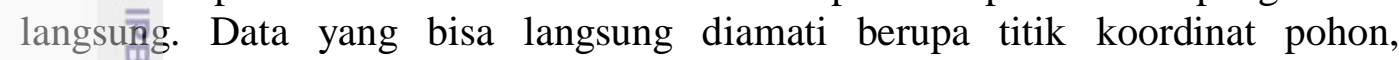
identifikasi spesies pohon, identifikasi kondisi pohon, dan dokumentasi pohon. Tahapẳn identifikasi lokasi pohon merupakan tahapan yang diperoleh dengan cara observàsi langsung ke lokasi tapak. Tahapan ini terdiri dari titik lokasi pohon (x latitude dan y longitude) yang diamati dengan menggunakan GPS (Global Positioning System) dengan cara membuat waypoint pada setiap pohon yang terdapẩt di jalur hijau jalan yang diamati satu-persatu. Jenis data, inventarisasi dapat ब̈ilihat pada tabel 3.

OPengamatan dilakukan di jalur hijau Jl. Pajajaran, Jl. Otto Iskandardinata, J1. Juañda dan Jl. Jalak Harupat. Pada Jl. Pajajaran pengamatan dilakukan mulai dari Lippo Keboen Raya hingga Mall Botani Square. Pada J1. Otto Iskandardinata pengamatan dilakukan dari Hotel Ammarosa- Lawang Selapan hingga Mall BTM. Pada J1. Juanda pengamatan dilakukan mulai dari Mall BTM hingga Sekolah Regina Pacis. Pada Jl. Jalak Harupat pengamatan dimulai dari YONIF hingga Lippo Keboen Raya. Jalur hijau jalan terbagi dua menjadi jalur hijau dalam dan jalur hijau luar. Jalur hijau dalam terletak berbatasan langsung dengan Kebun Raya Bogor dan jalur hijau luar terletak setelah jalan jika dilihat dari atas/ citra satelit. Jalur hijau dalam diberi kode "A" dan jalur hijau luar diberi kode "B". Letak pembagian jalur hijau dapat dilihat di gambar 3.

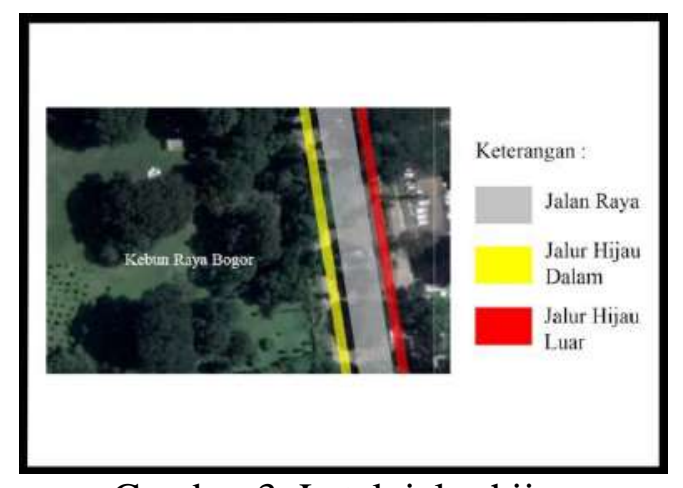

Gambar 3. Letak jalur hijau 
Tabel 3. Jenis data inventarisasi

\begin{tabular}{|c|c|c|c|c|}
\hline No & Jenis Data & Parameter & Bentuk & Sumber \\
\hline 1 & Letak Geografis & $\begin{array}{l}\text { Batas, luas, wilayah, } \\
\text { akses }\end{array}$ & Data sekunder & $\begin{array}{l}\text { BAPPEDA, } \\
\text { literature, } \\
\text { survei lapang } \\
\end{array}$ \\
\hline 2 & Vegetasi & $\begin{array}{l}\text { Jenis pohon, jumlah, } \\
\text { letak, kondisi }\end{array}$ & $\begin{array}{l}\text { Data primer } \\
\text { dan Sekunder }\end{array}$ & $\begin{array}{l}\text { Survei lapang } \\
\text { dan literatur }\end{array}$ \\
\hline $\begin{array}{l}3 \\
(0) \\
\frac{T}{\pi}\end{array}$ & Kualitas udara & $\begin{array}{lr}\text { Jenis zat } & \text { pencemar, } \\
\text { sumber } & \text { pencemar, } \\
\text { jumlah } & \text { zat } \\
\text { pencemar, } & \text { baku } \\
\text { mutu } & \\
\end{array}$ & Data sekunder & Literatur \\
\hline$\frac{4}{3}$ & Sampel daun & $\begin{array}{l}\text { Kadar air, } \mathrm{pH}, \\
\text { kandungan } \\
\text { kandungan } \\
\begin{array}{l}\text { kskofil, } \\
\text { askorbat }\end{array}\end{array}$ & Data primer & $\begin{array}{l}\text { Survei lapang } \\
\text { dan literatur }\end{array}$ \\
\hline
\end{tabular}

\section{İdentifikasi Karakteristik Jalur Hijau Jalan}

Tahap identifikasi karakteristik jalur hijau jalan dilakukan secara deskriptif dengan pengamatan langsung pada jalur tersebut secara visual. Pengamatan dilakukan dengan mengamati pola, struktur, karakter dan kesan visual pada bägianbagian jalan seperti median jalan, bangunan pada tepi jalan, utilitas, dan jalur pedestrian jalan. Identifikasi karakter jalur hijau juga dilakukan dengan pengambilan gambar melalui kamera. Selain itu juga dilakukan identifikasi jenis Pegetasi pada jalur hijau jalan.

Identifikasi jenis vegetasi dilakukan untuk mengetahui jenis-jenis pohon serta komposisi dan persebaran pohon pada Jalur Lingkar Luar Kebun Raya Bogor. Identifikasi jenis vegetasi dilakukan secara spasial berdasarkan hasil inventarisasi yang telah dilakukan sebelumnya dengan menggunakan GPS. Kemudian data tersebut diolah dengan menggunakan aplikasi Google earth untuk mengetahui titik lokasi tiap pohon pada Lingkar Luar Kebun Raya Bogor. Setelah diolah menggunakan Google earth kemudian data tersebut diolah dengan melakukan digitasi tajuk pohon menggunakan aplikasi ArcGIS dan AutoCad. Hasil akhir dari identifikasi jenis vegetasi berupa tabel jenis-jenis pohon serta pemetaan spasial persebaran pohon pada Lingkar Luar Kebun Raya Bogor.

\section{Analisis Deskriptif}

Pada penelitian ini dilakukan analisis deskriptif untuk mengetahui (kesesuaian karakter fisik masing-masing pohon pada jalur hijau Lingkar Luar Kebun Raya Bogor dalam mengurangi polusi. Analisis secara deskriptif dilakukan dengan melakukan skoring pada pohon yang telah diindentifikasi pada Lingkar Euar Kebun Raya Bogor. Skoring tersebut dilakukan pada fungsi ekologis jalur hijau jalan untuk mereduksi polusi dan menjerap partikel yang kemudian dilakukan pemetaan secara spasial kesesuaian fungsi ekologis jalur hijau dalam menyerap polusi dan menjerap partikel. Penilaian dilakukan terhadap elemen 
pohon pada jalur hijau jalan, dengan membandingkan ciri fisik serta kondisi lapang vegetasi pada jalur hijau jalan dengan kriteria-kriteria yang dikumpulkan dari berbagai sumber pustaka, terhadap fungsi jalur hijau jalan dalam menyerap polutan gas dan menjerap partikel. Kriteria pohon untuk penyerap polutan dan penjerap partikel padat disajikan pada tabel 4.

Tabel 4. Kriteria fungsi ekologis

Aspek fungsi pohon Kriteria penilaian

Penyerap polusi gas

1. Kepadatan tajuk ${ }^{1}$

2. Daun tipis ${ }^{2}$

3. Jumlah daun banyak ${ }^{3}$

Penjerap polusi partikel

1. Struktur permukaan, tepi daun kasar, berlekuk, berbulu/ bertrikoma ${ }^{4}$

2. Daun jarum atau daun lebar ${ }^{5}$

3. Kepadatan tajuk ${ }^{6}$

4. Tekstur kulit batang dan ranting kasar, ranting berduri ${ }^{\top}$

5. Kepadatan ranting ${ }^{8}$

Sumber : Dahlan (1989) ${ }^{4,7, \text { dan } 8}$, Fakuara (1986) ${ }^{1,3,5 \text {, dan } 6}$, Patra $(2002)^{2}$, Taihuttu $(2001)^{\frac{5}{2}}$

\Penilaian dilakukan untuk tiap jenis spesies pohon. Untuk masing-masing kriteria penilaian diberikan dengan nilai antara 1 hingga 4 berdasarkan kesesuaian ciri fisik dan kondisi lapang pohon dengan kriteria penilaian dimana nilai 1 berarti tidak sesuai, 2 berarti kurang sesuai, 3 berarti sesuai, dan 4 berarti sangat sesuai dengan kriteria penilaian. Nilai maksimal atau nilai ideal untuk tiap kriteria adalah 4. Nilai yang didapat dari tiap kriteria dijumlahkan kemudian dibandingkan dengan jumlah ideal atau nilai maksimum dari tiap kriteria penilaian. Hasil perbandingan kemudian diubah ke dalam bentuk persen untuk mendapatkan persentase nilai evaluasi. Dari penilaian tersebut didapatkan hasil penilaian dalam bentuk persentase.

$$
\text { Nilai Evaluasi }=\frac{\text { Jumlah total kriteria penilaian }}{\text { Jumlah total nilai ideal kriteria penilaian }} \times 100 \%
$$

Hasil penilaian tersebut kemudian dikelompokkan dalam empat kategori penilaian yaitu sangat sesuai, sesuai, kurang sesuai, tidak sesuai. Pengelompokkan hasil penilaian menggunakan 5 selang dimana nilai bobot sempurna yaitu $100 \%$ dibagi menjadi 5 selang sama besar, sebesar $20 \%$. Nilai 100\%-81\% merupakan kategori sangat sesuai, 81\%-61\% merupakan kategori sesuai, 60\%-41\% merupakan kategori kurang sesuai, dan nilai $40 \%$ atau kurang dari itu termasuk kedalam kategori tidak sesuai. Untuk penelitian ini, selang $40 \%$ terendah dikelompokkan dalam satu kategori tidak sesuai. Pembobotan $40 \%$ terendah untuk kategori tidak sesuai ditujukan untuk meningkatkan standar penilaian (Hidayat, 2008) 


\section{Penilaian Kondisi Lapangan untuk Kategori Penyerap Gas}

\section{Kepadatan Tajuk}

Kepadatan tajuk pohon mempengaruhi keefektifan penyaringan zat pencemar udara. Tajuk yang rapat dapat menyerap polusi lebih baik dibanding tajuk yang terbuka. Kepadatan tajuk diukur persentase dari total cahaya yang diblokir oleh pepohonan, dapat dilihat di Gambar 4.

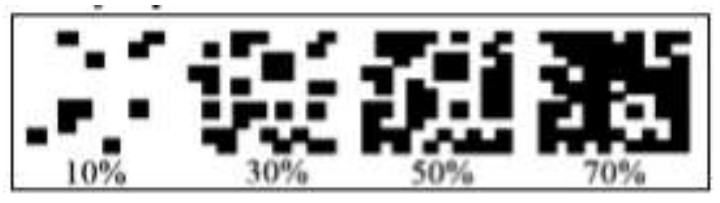

Gambar 4. Ilustrasi persentase total cahaya yang diblokir oleh pepohonan klasifikasi kerapatan tajuk pohon

$\overline{\mathrm{K}}$ lasifikasi kepadatan tajuk:

Nilai 1 : Sangat jarang $0-10 \%$

Hilai 2 : Jarang $11-40 \%$

Nilai 3 : Sedang $41-70 \%$

Nilai 4 : Lebat $71-100 \%$

ग

\section{Daun Tipis}

Ketebalan daun mempengaruhi penyerapan gas. Daun yang tipis akan lebih mudah menyerap gas dan lebih baik untuk mereduksi zat pencemar udara. Tebal dan tipisnya daun dipengaruhi oleh bentuk daging daun. Daging daun merupakan isi dari daun. Daging daun dibedakan menjadi tipis seperti selaput, tipis seperti kertas, tipis lunak, tipis perkamen/kaku, seperti kulit dan berdaging (Rosanti, 2011)

Klasifikasi ketipisan daun:

Nilai 1: Seperti kulit (ex: daun nyamplung) dan Berdaging (ex: daun lidah buaya)

Nilai 2: Tipis perkamen (ex: daun kelapa)

Nilai 3: Tipis lunak (ex: daun selada air)

Nilai 4: Tipis seperti selaput (ex: daun paku selaput) dan Tipis seperti kertas (ex: daun pisang).

\section{Jumlah Daun Banyak}

Daun berperan penting dalam menyerap polutan udara. Jumlah daun pada suatu pohon dapat mempengaruhi penyerapan zat pencemar. Pohon dengan jumlah daun yang banyak lebih baik dalam penyerapan zat pencemar sehingga dapat mereduksi polusi dengan lebih baik. Metode estimasi jumlah daun hampir sama dengan cara metoda kepadatan tajuk, yang berbeda yaitu dilihat dari banyaknya daun per cabang pada pohon tersebut.

Klasifikasi banyaknya daun:

Nilai 1 : Sangat jarang 0-10\%

Nilai 2 : Jarang $11-40 \%$ 
Nilai 3 : Sedang $41-70 \%$

Nilai 4 : Lebat $71-100 \%$.

\section{Penilaian Kondisi Lapangan untuk Kategori Penjerap Partikel}

\section{Struktur permukaan, tepi daun kasar, berlekuk, berbulu/ bertrikoma}

Kondisi permukaan daun yang memiliki trikoma (bulu halus) memiliki kemapuan lebih baik dalam menjerap partikel. Trikoma berperan sebagai tiang tiang yang menjebak partikel yang jatuh padah permukaan pohon. Ada beberapa jenis pohon yang memiliki tipe trikoma glanduler yang menghasilkan sekret. Semakin tinggi kemampuan sekresi suatu trikoma maka semakin baik keman̂puannya dalam menjerap partikel

Klasifikasi struktur permukaan daun:

Nilai E: Daun mengkilap, licin, tidak terdapat trikoma

Nilai 2: Daun tidak memiliki trikoma, tidak terlalu mengkilap

Nilai 3. Daun memiliki trikoma setelah dilihat menggunakan lup

Nilai 4. Daun memiliki trikoma secara kasat mata

\section{Daün jarum atau daun lebar}

đUkuran daun yang lebar mempengaruhi luasan jerapan partikel. Semakin luas mäka semakin banyak partikel yang terjerap. Sementara daun jarum memiliki struktür kasar seperti trikoma sehingga lebih efektif dalam menjerap partkel. Klasifikasi ini mengacu pada klasifikasi luasan daun oleh Raunkiaer 1934.

\&

Klasifikasi luas daun:

Nilai 1 : Nanophyl $\left(0,25-2,25 \mathrm{~cm}^{2}\right)$

Nilai 2 : Microphyl $\left(2,25-20,25 \mathrm{~cm}^{2}\right)$

Nilai 3 : Mesophyl $\left(20,25-182,25 \mathrm{~cm}^{2}\right)$

Nilai 4 : Berdaun jarum, macrophyl $\left(>182,25 \mathrm{~cm}^{2}\right)$

\section{Kepadatan Tajuk}

Kepadatan tajuk pohon mempengaruhi keefektifan penjerapan zat pencemar udara. Tajuk yang rapat dapat menjerap partikel lebih baik dibanding tajuk yang terbuka. Kepadatan tajuk diukur persentase dari total cahaya yang diblokir oleh pepohonan, dapat dilihat di Gambar 5.

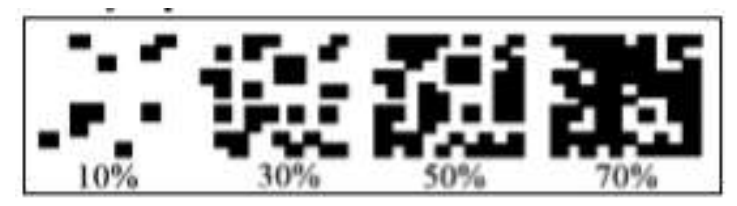

Gambar 5. Ilustrasi persentase total cahaya yang diblokir oleh pepohonan klasifikasi kerapatan tajuk pohon

Klasifikasi kepadatan tajuk:

Nilai 1: Sangat jarang 0-10\%

Nilai 2: Jarang 11-40\% 
Nilai 3 : Sedang $41-70 \%$

Nilai 4 : Lebat $71-100 \%$

\section{Tekstur kulit batang dan ranting kasar, ranting berduri}

Batang pohon memiliki peran dalam menjerap partikel. Kriteria batang pohon yang mampu menjerap partikel adalah batang yang memiliki tekstur kasar. Semakin kasar maka semakin baik kemapuannya. Klasifikasi tekstur batang disajikan pada gambar 6 dibawah ini.

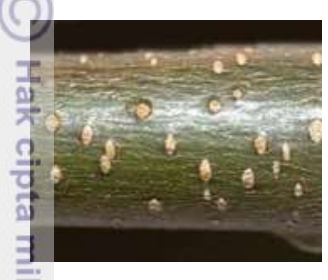

1

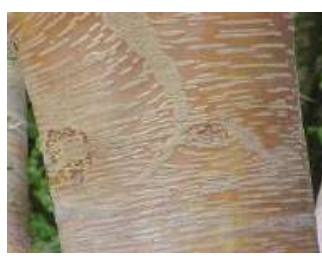

2

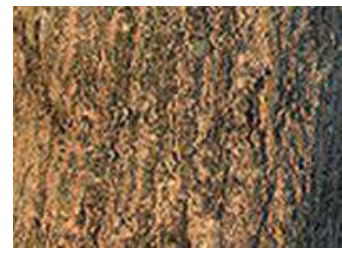

3

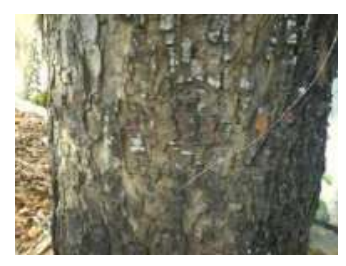

4

Gambar 6 . Klasifikasi tekstur batang

Sumber: Dokumentasi pribadi

Klasifikasi tekstur batang:

Nilai 1 : Tekstur batang licin, mirip batang herba

Nilai 2 : Tekstur batang licin dengan lentisel yang menyebar

甘ilai 4 : Tekstur batang kasar secara visual dan rabaan

Yilai 5 : Tekstur batang sangat kasar secara visual dan rabaan, berduri

\section{Kepadatan ranting}

Ranting memiliki peran sebagai media jerapan bagi partikel. Kepadatan ranting setara dengan kepadatan tajuk. Penilaian yang digunakan sama dengan tajuk. Semakin banyak ranting maka semakin luas dari total serapan partikelnya.

Klasifikasi kepadatan ranting

Nilai 1 : Sangat jarang 0-10\%

Nilai 2 : Jarang $11-40 \%$

Nilai 3 : Sedang $41-70 \%$

Nilai 4 : Lebat $71-100 \%$.

\section{Metode Pengambilan Contoh}

Contoh yang diambil berupa daun segar dari setiap jenis pohon. Daun yang diambil dipilih dari pohon yang sehat bebas penyakit dan gangguan hama. Kriteria daun sampel yang diambil mengacu pada Sukarsono dalam Hermawan et al. (2011), Daun yang diambil berada di sisi yang menghadap jalan dengan ciri daun telah membuka sempurna, berwarna hijau, menempati posisi kedua atau ketiga dari pangkal ranting, tidak mengalami kerusakan dari hama dan penyakit. Daun yang diambil berada ketinggian 1,5-2,5 m dari tanah. Ilustrasi pengambilan contoh bisa dilihat pada gambar 7 . 


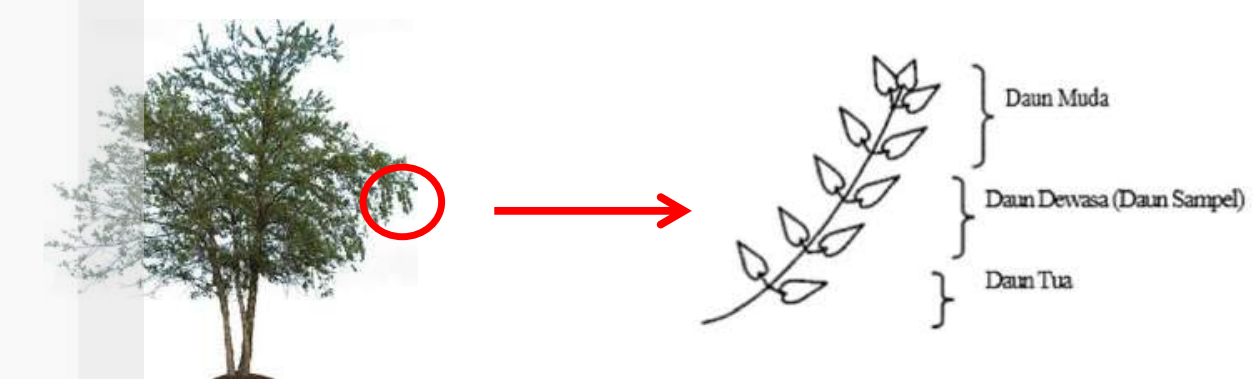

Gambar 7. Metode pengambilan sampel daun

Sumber: Hermawan et al., 2011

Pengambilan dilakukan pada pagi hari pukul 06.00-07.00 guna menghündari kemungkinan evapotransipirasi tanaman yang terjadi. Prosedur pengambilan sampel daun contoh dilakukan dengan memilih ranting daun yang sehat dengan ciri-ciri memiliki warna hijau, tidak ada kerusakan yang diakibatkan hama atau penyakit dan juga tidak terhalangi benda lain dari jalan raya. Setelah sampef daun dipilih, dimasukkan ke dalam kantong klip plastik secara terpisah berdasarkan jenisnya. Selanjutnya daun contoh tersebut dibawa ke laboratorium untuk dianalisis kandungan biokimianya. Daun sampel yang akan dianalisis harus segar đalam artian hari dimana daun itu diambil maka hari itu juga daun harus dianalisis untuk menghindari perubahan kandungan biokimia daun itu sendiri.

\section{Analisis APTI}

Dalam Penelitian ini dilakukan analisis APTI (Air Pollution Tolerance Index) pada daun setiap jenis spesies pohon. Analisis APTI dilakukan untuk mengetahui tingkat kepekaan spesies pohon terhadap zat polusi. Hasil analisis APTI dapat digunakan untuk memilih tanaman yang memiliki toleransi terhadap polusi udara. Nilai APTI pada spesies tanaman yang berbeda dihitung dengan menggabungkan nilai kandungan asam askorbat, $\mathrm{pH}$ daun, kandungan total klorofil dan kandungan air relatif menjadi suatu persamaan matematika sebagai berikut

$$
\mathrm{APTI}=\frac{A(T+P)+R}{10}
$$
A : Kandungan asam askorbat $(\mathrm{mg} / \mathrm{g})$
$\mathrm{T}$ : Kandungan total klorofil $(\mathrm{mg} / \mathrm{g})$
$P$ : Niłai pH ekstrak daun
$\mathrm{R}$ : Kandungan air relatif daun $(\%)$

Kandungan asam askorbat sampel daun dianalis dengan menggunakan metode Oktariya (2017). Pengukuran asam askorbat dilakukan dengan metode iodometri. Hal pertama yang dilakukan yaitu membuat ekstrak dari contoh yang telah diambil. Pembuatan ekstrak ini dilakukan pada keadaan daun yang masih segar@ 
Pembuatan ekstrak daun

1. Menimbang daun sebanyak $50 \mathrm{~g}$

2. Menghancurkan daun dengan mortar atau blender sambai halus, lalu ambil 0,5 g

3. Melarutkan 0,5 gr daun kedalam $50 \mathrm{ml}$ akuades

4. Mengambil filtrate sebanyak $25 \mathrm{ml}$, kemudian mengencerkan lagi pada labu ukur $100 \mathrm{ml}$

Titrasi

E Memasukan filtrate ke dalam labu Erlenmeyer

Menambahkan 3 tetes indikator amilum 1\%

Dititrasi dengan $\mathrm{H}_{2} \mathrm{SO}_{4} 10 \%$ sebanyak $5 \mathrm{ml}$

Dititrasi dengan iodium sampai terbentuk warna biru

$\overline{\bar{K}}$ andungan asam askorbat kemudian dihitung dengan persamaan sebagai berikut

एँ

竞

Asam askorbat $(\mathrm{mg} / \mathrm{g})=\frac{\left[\left(V I_{2} \times(V t / V f)\right] \times A\right.}{W}$

Keterangan :

VI2 : Volume rata-rata Iodium

$\forall \mathrm{t}$ : Volume total filtrate

$\forall f:$ Volume filtrate yang digunakan

A : kesetaraan $\mathrm{I}_{2}$ dengan vitamin $\mathrm{C}$

Kandungan total klorofil a dan $\mathrm{b}$ dihitung dengan metode yang digunakan oleh Maclachlan dan Zalic (1963). Sampel daun yan telah diambi kemudian dianalisis seperti berikut:

1. Timbang sampel daun yang sudah dipotong sebanyak 1 gr

2. Haluskan daun menggunakan mortar, lalu tambahkan $20 \mathrm{ml}$ aseton $80 \%$

3. Saring larutan menggunkan kertas saring

4. Sentrifugasi pada $3000 \mathrm{rpm}$ selama 15 menit

5. Ambil supernatant yang telah terbentuk, tambahkan aseton $80 \%$ hingga volume mencapai $25 \mathrm{ml}$

6. Selanjutnya supernatant diukur dengan spektrofometer dengan panjang gelombang A663 nm dan A645 nm

Total klorofil a dan b kemudian diukur menggunakan persamaan

$$
\begin{gathered}
\text { Klorofil } \mathrm{a}=12,7(A 663)-2,69(A 645) \times \frac{V}{1000 \times W} \\
\text { Klorofil } \mathrm{b}=22.9(A 645)-4.68(A 663) \times \frac{V}{1000 \times W} \\
\text { Total klorofil }(\mathrm{mg} / \mathrm{g})=\text { klorofil } \mathrm{a}+\text { klorofil } \mathrm{b}
\end{gathered}
$$



A : Absorbansi pada gelombang yang ditentukan
$\mathrm{V}$ : Volume klorofil pada $80 \%$ aseton $(\mathrm{ml})$
$\mathrm{W}$ : Berat sampel segar (mg)

Untuk menghitung nilai $\mathrm{pH}$ ekstrak daun dilakukan prosedur pertama sebanyak $5 \mathrm{~g}$ sampel dihancurkan kemudian dihomogenisasi dalam $50 \mathrm{ml}$ akuades. Setelah itu sampel disentrifugasi dan supernatan digunakan untuk mendeteksi $\mathrm{pH}$ dengan menggunakan $\mathrm{pH}$ meter digital yang telah dikalibrasi terlebih dahulu pada $\mathrm{pH} 4$ dan $\mathrm{pH} 10$.

Kandungan air relatif dihitung dengan menggunakan metode Sen dan Bhandâri (1978). Setelah sampel diambil dilakukan analisis seperti berikut

1. Timbang sampel daun segar menggunakan neraca digital, catat beratnya sebagai FW (fresh weight)

2. Reñdam daun yang masih segar kedalam cairan akuades, pastikan daun terendam selama semalaman

3. Setelah direndam semalaman, keringkan daun dengan tisu

4. Tim̄mbang daun yang sudah direndam untuk mengetahui TW (turgid weight)

5. Daun kemudian di oven selama semalam dengan suhu $80 \mathrm{o}$

6. Setelah dioven berat daun ditimbang lagi untuk mengetahui DW (dry weight)

Hasil kadar air daun diperoleh dengan cara perbandingan fresh weight dikurangi dry wêight dengan turgid weight dikurang dry weight dikali $100 \%$ dengan menggunakan rumus

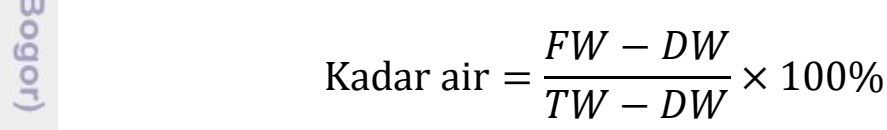

Setelah nilai APTI dihitung dan diketahui, nilai diklasifikasikan berdasarkan tingkat toleransinya. APTI memiliki rentang nilai dari 100 hingga 1. Nilai yang paling tinggi adalah 100 dengan kelas toleran dan nilai paling rendah adalah 1 dengan kelas sangat sensitive. Klasifikasi yang lengkap disajikan di tabel 5 .

Tabel 5. Klasifikasi tanaman berdasarkan nilai toleransinya

\begin{tabular}{ll}
\hline Nilai APTI & Respon Tanaman \\
\hline$>20$ & Toleran \\
$17-20$ & Cukup toleran \\
$12-160$ & Sedang \\
$<120$ & sensitif \\
\hline
\end{tabular}

Sumber : Sing dan Rao, 1991

OSetelah semua penilaian diperoleh, diberi pembobotan nilai untuk mengetahui hubungan antara evaluasi fungsi fisik dan toleransinya terhadap polusi udara. Setiap aspek evaluasi memiliki 4 tingkat kategori, sehingga diberi nilai 1 hingga 4 untuk pembobotan nilainya. Nilai 1 untuk kategori terendah dan nilai 4 untuk kategori tertinggi. Nilai total pembobotan adalah 12. Nilai pembobotan dapatdilihat pada tabel 6 dibawah ini. 
Tabel 6. Pembobotan nilai evaluasi fungsi fisik dengan toleransi

\begin{tabular}{|c|c|c|}
\hline Evaluasi & Kategori & Nilai \\
\hline \multirow{4}{*}{$\begin{array}{l}\text { Fungsi fisik sebagai } \\
\text { penyerap gas }\end{array}$} & Sangat sesuai & 4 \\
\hline & Sesuai & 3 \\
\hline & Kurang sesuai & 2 \\
\hline & Tidak sesuai & 1 \\
\hline \multirow{4}{*}{$\begin{array}{l}\text { Fungsi fisik sebagai } \\
\text { penjerap partikel }\end{array}$} & Sangat sesuai & 4 \\
\hline & Sesuai & 3 \\
\hline & Kurang sesuai & 2 \\
\hline & Tidak sesuai & 1 \\
\hline \multirow{5}{*}{$\begin{array}{l}\text { APTI } \\
\text { APT } \\
\frac{0}{0} \\
\frac{0}{0} \\
3 \\
3 \\
\end{array}$} & Toleran & 4 \\
\hline & Cukup Toleran & 3 \\
\hline & Sedang & 2 \\
\hline & Sensitif & 1 \\
\hline & nilai & 12 \\
\hline
\end{tabular}

$\overline{\bar{v}}$

- Nilai yang diperoleh kemudian dihitung dengan rumus persetase seperti berikut

छ Nilai Evaluasi $=\frac{\text { Total nilai yang diperoleh }}{\text { Total nilai } \text { ideal }} \times 100 \%$

Klasifikasi evaluasi sebagai tanaman yang cocok untuk daerah terpolusi

Sangat sesuai : $>75 \%$

Sesuai : $51 \%-75 \%$

Kurang sesuai : $26 \%-50 \%$

Tidak sesuai $:<25 \%$

\section{Perumusan Rekomendasi}

Hasil dari penelitian ini digunakan untuk mengetahui kesesuaian fisik dan index toleransi spesies pohon terhadap polusi udara. Berdasarkan hasil evaluasi dan literatur kemudian dijadikan rekomendasi komposisi jalur hijau jalan yang diharapkan mampu mengurangi sebaran polusi gas dan polusi partikel. 


\section{HASIL DAN PEMBAHASAN}

\section{Kondisi Umum}

Jalan Lingkar Luar Kebun Raya Bogor terletak di Kecamatan Bogor Tengah, Kota Bogor, Jawa Barat, dengan koordinat 106 48' BT dan 06 36' LS. Jalan ini meliputi empat jalan besar yaitu Jalan Ir. Haji Juanda atau Jalan Juanda, Jalan Jalak Harupat, Jalan Pajajaran, dan Jalan Otto Iskandardinata atau Jalan Otista. Batas tapak dari jalan ini di masing-masing arah adalah sebagai berikut:

- Barat : Kelurahan Paledang

- Utara Kelurahan Babakan, Kelurahan Sempur, dan Kelurahan Pabaton

- Timur : Kelurahan Tegalega, Kelurahan Babakan

- Selatân : Kelurahan Babakan Pasar, dan Gudang

SStatus dan fungsi jalan dari Jalan Juanda, Jalan Jalak Harupat, dan Jalak Otista memliki status sebagai jalan provinsi dan berfungsi sebagai jalan kolektor primes. sedangkan Jalan Pajajaran adalah jalan nasional dengan fungsi arteri sekunđer. Keempat jalan memiliki jenis perkerasan aspal dan memiliki panjang yang berbeda-beda dengan total panjang $4,2 \mathrm{~km}$. Jalan Juanda merupakan jalan terpanjang dengan panjang 1,68 km, Jalan Jalak Harupat memiliki panjang 1.04 $\mathrm{km}$, Ja $0,7 \mathrm{~km}$. Lebar jalan yang terdiri dari jalur lalu lintas dan jalur pedestrian juga memiliki lebar yang berbeda-beda.

1 Kondisi iklim di Kota Bogor suhu rata-rata tiap bulan $27,3^{\circ} \mathrm{C}$ dengan suhu tệrendah $22,2^{\circ} \mathrm{C}$ dengan suhu tertinggi $33,0^{\circ} \mathrm{C}$. Kelembaban udara $82 \%$, denga $\bar{n}$ kecepatan angin rata-rata adalah 6.1 knot. Curah hujan rata-rata setiap bulan sekitar 345 mm (BPS Kota Bogor, 2018)

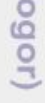

\section{Kondisi Jalan dan Transportasi Kota Bogor}

Kondisi jalan di Lingkar Luar Kebun Raya sudah diaspal dan dapat dilintasi kendaraan bermotor roda dua dan kendaraan roda 4 dengan sistem satu arah. Kondisi jaringan jalan eksisting berdasarkan kelompok fungsinya yang terdapat di Kota Bogor terdiri dari jalan arteri primer, arteri sekunder, kolektor sekunder, Lokal primer, lingkungan primer dan lingkungan sekunder. Jalan-jalan di Lingkar Luar Kebun Raya Bogor termasuk kedalam jalan arteri primer yang berada di pusat Kota Bogor. Seperti yang telah diketahui sebelumnya bahwa frekuensi kendaraan yang melintas tinggi pada suatu jalan akan mengeluarkan emisikendaraan yang besar pula. Oleh karena itu, pentingnya dilakukan rekayasa tata hijau untuk bisa menanggulangi masalah tersebut. 


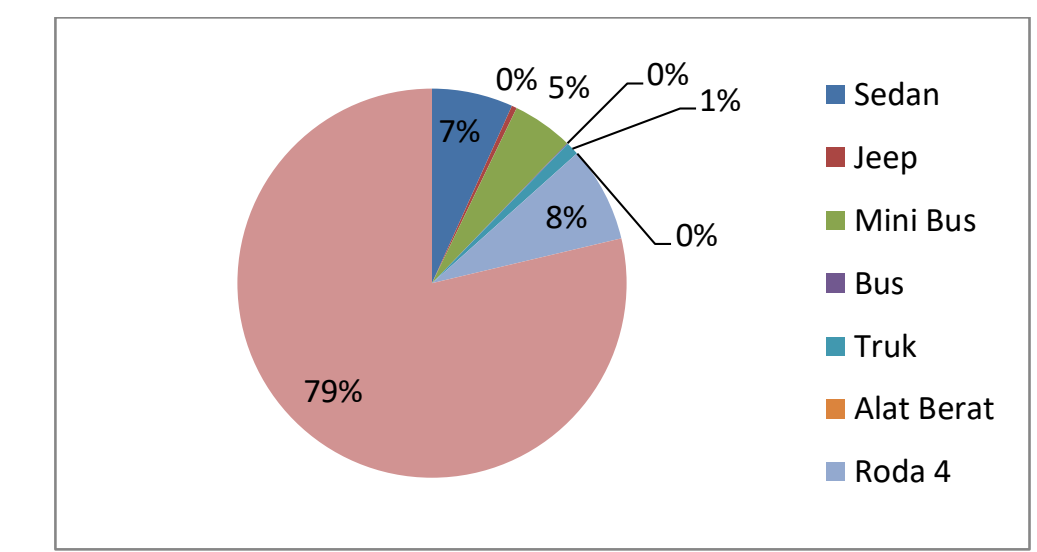

Gambar 8. Persentase jenis kendaraan di Kota Bogor tahun 2016 Sumber: BPS Jawa Barat 2018

Persentase jenis kendaraan di Kota Bogor pada tahun 2016 yang disajikan pada gambar 8 dapat disimpulkan bahwa jenis kendaraan roda dua mendominasi populasi. Jumlah kendaraan bermotor umum dan publik hingga tahun 2016 di Kota Bogor menurut BPS Jawa Barat berjumlah 1.220.974 kendaraan. Jumlah Kendaraan di Kota Bogor dengan jenis kendaraan roda dua dengan jumlah \%60.923 buah, diikuti kendaraan roda empat dengan jumlah 96.741 buah, sedan sejumlah 82.272 buah, minibus sejumlah 61.754 buah, truk sejumlah 13.231 buah, jeep sejumlah 5.274 buah, bus sejumlah 806 buah, dan alat berat sebanyak 2 buah.

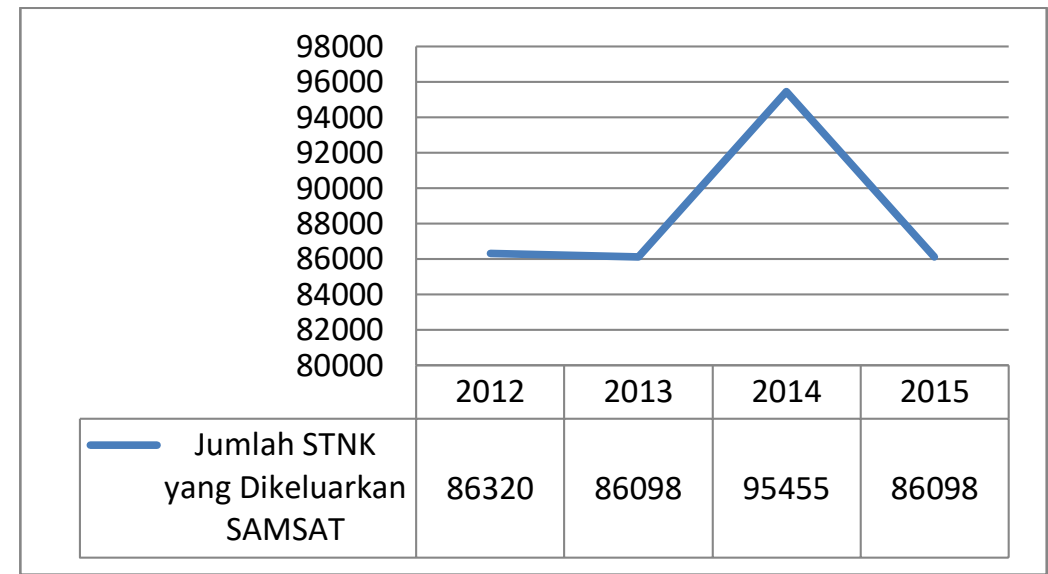

Gambar 9. Jumlah STNK yang dikeluarkan SAMSAT Kota Bogor Sumber : BPS Kota Bogor, 2018

Setiap tahun terjadi peningkatan jumlah kendaraan bermotor meliputi mobil penumpang, mobil barang, mobil bus, dan sepeda motor. Gambar 9 menunjukan kenaikan yang signifikan terjadi pada tahun 2014 dengan jumlah STNK yang dikeluarkan sejumlah 95.455 kendaraan. Rata- rata jumlah STNK yang dikeluarkan dari 2012 hingga 2015 yaitu 88492 STNK per tahun. Kenaikan jumlah kendaraan bermotor tiap tahunnya menyebabkan konsentrasi polutan di \#dara terus meningkat. 


\section{Kondisi Transportasi Sistem Satu Arah di Lingkar Luar Kebun Raya Bogor}

Penerapan jalur Sistem Satu Arah (SSA) pada ruas jalan yang melingkari Kebun Raya Bogor mulai dilaksanakan pada bulan Maret 2016. Penerapan jalur SSA dilakukan sebagai upaya untuk mengurangi tingkat kemacetan yang terjadi pada jalur tersebut. Pada tahun sebelumnya terdapat dua arah pada setiap jalan, perbandingan arah lalu lintas disajikan pada gambar berikut
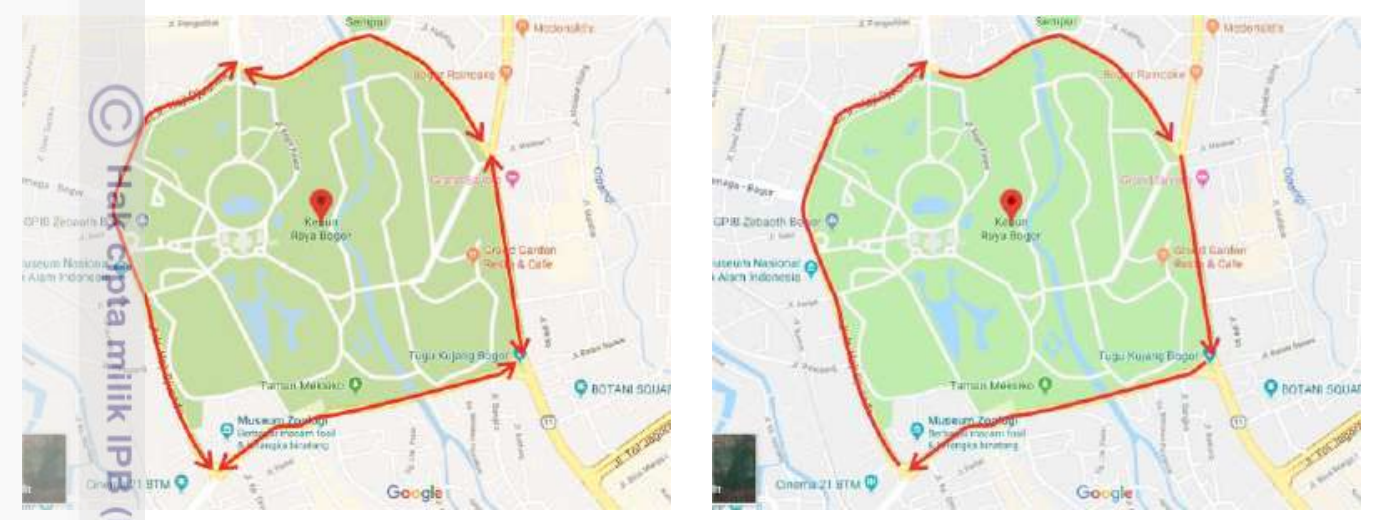

Gambar 10. Arah Sirkulasi Sebelum Penerapan SSA (kiri) dan Sesudah (kanan)

Sumber : Google Maps 2019 dengan modifikasi

Tabel 7. Perbandingan volume rata-rata kendaraan sebelum pada tahun 2015 dan sesudah penerapan SSA pada tahun 2017

\begin{tabular}{cccc}
\hline & Segmen & \multicolumn{2}{c}{$\begin{array}{c}\text { Volume Rata-rata Kendaraan } \\
\text { (kendaraan/jam) }\end{array}$} \\
\cline { 2 - 4 } Namga Jalan & $\begin{array}{c}\text { Sebelum } \\
\text { (Awal - Akhir) }\end{array}$ & $\begin{array}{c}\text { Sesudah } \\
\text { (tahun 2017) }\end{array}$ \\
\hline J1. Pajajaran & $\begin{array}{c}\text { Rumah Dinas - Tugu } \\
\text { Kujang }\end{array}$ & 1.732 & 3.343 \\
\hline $\begin{array}{c}\text { Jl. Otto } \\
\text { Iskandardinata }\end{array}$ & $\begin{array}{c}\text { Tugu Kujang - Ps. } \\
\text { Bogor }\end{array}$ & 3.461 & 4.659 \\
\hline J1. Haji Djuanda & $\begin{array}{c}\text { SMA 1 - BNI } \\
\text { Paledang }\end{array}$ & 2.902 & 3.285 \\
\hline J1. Jalak Harupat & $\begin{array}{c}\text { Sempur - Rumah } \\
\text { Dinas }\end{array}$ & 2.384 & 3.132 \\
\hline
\end{tabular}

Sumber : Suhandi 2017

Setelah penerapan SSA terdapat perubahan pada juamlah kendaraan, kecepatan kendaraan rata-rata, rasio segmen jalan, dan tingkat pelayanan jalan. Setelah penerapan SSA, kecepatan kendaraan rata-rata mengalami kenaikan. Pada J1. Pajajaran volume kendaraan meningkat dari 1.732 kendaraan/jam menjadi 3.343 kẻndaraan/jam; Jl. Otto Iskandardinata dari 3.461 kendaraan/jam meningkat menjadi 4.659 kendaraan/jam; Jl. Haji Djuanda dari 2.902 kendaraan/jam meningkat menjadi 4.285 kendaraan/jam; Jl. Jalak Harupat dari 2.384 kendaraan/jam meningkat menjadi 3.132 kendaraan/jam. Pada ruas jalan Pajajaran kecepatannnya naik dari $22.86 \mathrm{~km} / \mathrm{jam}$ menjadi $42.2 \mathrm{~km} / \mathrm{jam}$; jalan Otto Iskandardinata dari $14.63 \mathrm{~km} / \mathrm{jam}$ menjadi $39.0 \mathrm{~km} / \mathrm{jam}$; jalan Ir. H. Djuanda naik 
dari $14.63 \mathrm{~km} / \mathrm{jam}$ menjadi $41.9 \mathrm{~km} / \mathrm{jam}$, dan jalan Jalak Harupat naik dari 14.78 $\mathrm{km} / \mathrm{jam}$ naik menjadi $41.7 \mathrm{~km}$. Nilai V/C ratio segmen jalan Pajajaran setelah penerapan SSA mengalami penurunan dari 0.61 menjadi 0.59 ; jalan Otto Iskandardinata setelah penerapan SSA mengalami penuruhan dari 0.77 menjadi 0.73; segmen jalan Ir. H Djuanda setelah penerapan SSA mengalami penurunan dari 0.79 menjadi 0.67 dan segmen jalan Jalak Harupat setelah penerapan SSA juga mengalami penurunan dari 0.76 menjadi 0.65 . Tingkat pelayanan jalan juga mengalami peningkatan pada segmen jalan Otto Iskandardinata, Ir. H. Djuanda dan jalan Jalak Harupat yang sebelumnya D menjadi C. Sedangkan untuk segmen jalan Pajajaran masih dalam tingkat layanan yang sama yaitu C. Tingkat pelayanan setelah penerapan Sistem Satu Arah (SSA) kesemua Program Studi Teknik Sipil Universitas Pakuan 10 segmen jalan adalah C, yang berarti Arus stabil, tapi kecepatan operasi mulai dibatasi oleh kondisi lalu lintas, Pengemudi mempunyai kebebasan yang cukup untuk memilih kecepatan. (Suhandi 2017).

\section{Kondisi Emisi dan Ambien di Kota Bogor}

Kondisi emisi di Kota Bogor salah satunya bersumber dari gas buang kendaraan bermotor. Hasil uji emisi yang dilakukan dibedakan dari jenis konsumsi bahan bakarnya yaitu kendaraan bermotor yang menggunakan bensin đan menggunakan solar. Volume emisi kendaraan bensin tertinggi terjadi pada tahun 2015 yaitu 400 kendaraan, dan terjadi penurunan pada 2014 menjadi 283. Kendaraan paling banyak yang tidak lolos uji ada pada tahun 2015 yaitu sebanyak 200 kendaraan. Sama seperti bensin, kendaraan yang menggunakan solarpalingbanyak tidak lolos uji pada tahun 2015 sejumlah 200 kendaraan. Grafik dapat dilihat pada gambar 11 dibawah ini
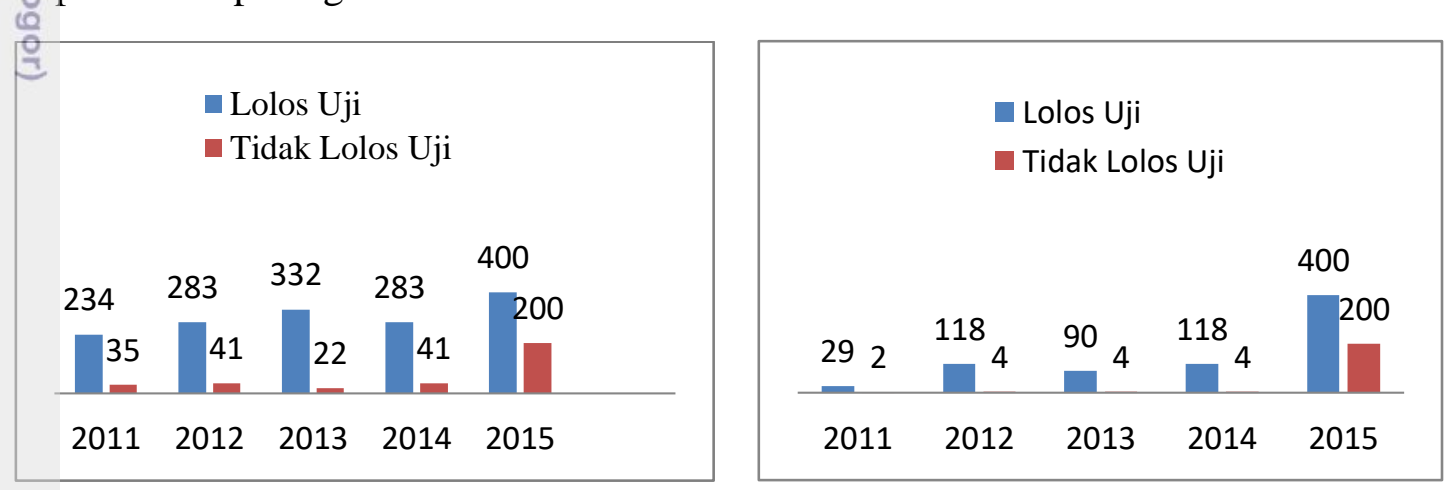

Gambar 11. Diagram emisi kendaraan bermotor berbahan bakar bensin (kiri), dan berbakan bahan solar (kanan) Kota Bogor Sumber: DLH Kota Bogor 2018

Keadaan udara ambien Lingkar Luar Kebun Raya Bogor dari tahun 2015 hingga tahun 2018 pada empat parameter meningkat, satu parameter menurun dan empat sisanya fluktuatif. Parameter yang meningkat antara lain $\mathrm{H}_{2} \mathrm{~S}, \mathrm{O}_{3}, \mathrm{SO}$, dan $\mathrm{Pb}$. Parameter yang menurun hanya $\mathrm{HC}$ sedangkan parameter yang fluktuatif terdiri dari debu, $\mathrm{NO} 2, \mathrm{CO}$, dan $\mathrm{NH}_{3}$. Data udara ambien hanya terdiri dari tahum 2015, 2016, dan 2018 karena pada tahun 2017 Dinas Lingkungan Hidup tidak melakukan pengukuran dengan parameter tersebut di lokasi yang sama. Perbandingan data yang terukur dan baku mutu dapat dilihat di tabel 8. 
Tabel 8. Keadaan ambien di Tugu Kujang dari tahun 2015-2018

\begin{tabular}{lcccc}
\hline Parameter & Baku & Nilai tahun & Nilai tahun & Nilai tahun \\
& Mutu & 2015 & 2016 & 2018 \\
\hline Amonia $\left(\mathrm{NH}_{3}\right)$ & 2 & 0,2 & 1,182 & $<0,1$ \\
Debu, TSP & 150 & 102 & 15,9 & 58 \\
Hidrogen sulfide $\left(\mathrm{H}_{2} \mathrm{~S}\right)$ & 24 & 0,5 & $<0,004$ & $131^{*}$ \\
Hidrocarbon $(\mathrm{HC})$ & 160 & 18 & 0,5 & $<13$ \\
Karbonmonoksida $(\mathrm{CO})$ & 10000 & 1334 & $<185,2$ & 1282 \\
Nitrogen dioksida $\left(\mathrm{NO}_{2}\right)$ & 150 & 55 & $<26,28$ & 61 \\
Ozon $\left(\mathrm{O}_{3}\right)$ & 135 & 19 & $<48,3$ & 124 \\
Sulfur dioksida $\left(\mathrm{SO}_{2}\right)$ & 365 & 19 & 50,5 & 157 \\
Timahhitam $(\mathrm{Pb})$ & 2 & 0,02 & $<0,05$ & $40^{*}$ \\
\hline
\end{tabular}

Keterangan : (*) diatas baku mutu menurut PP No. 41 Tahun 1999

Sumber: DLH Kota Bogor 2018

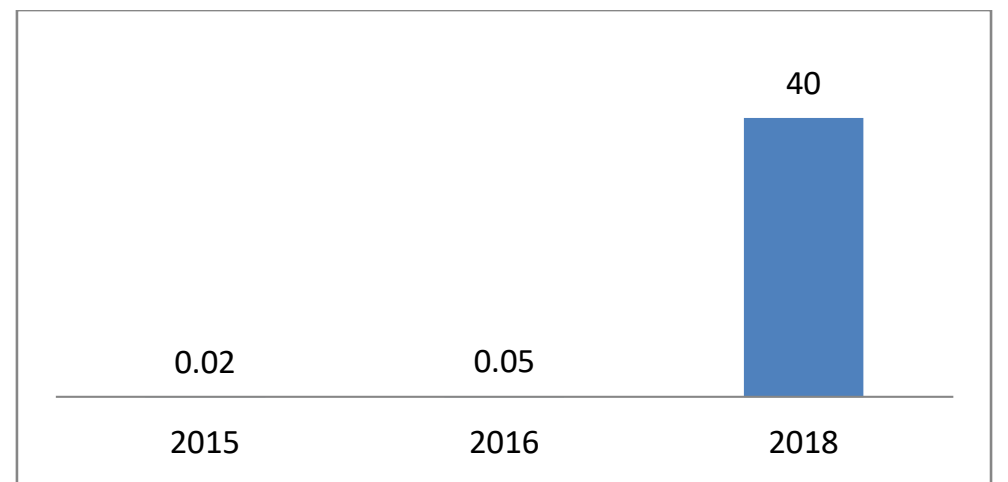

Gambar 12. Kandungan udara ambien $\mathrm{Pb}$ pada tahun 2015-2018 Sumber : DLH Kota Bogor 2018

Menurut PP no. 41 Tahun 1999 tentang pengendalian ambien udara, baku mutu $\mathrm{Pb}$ di udara adalah $1 \mu \mathrm{g} / \mathrm{m}^{3}$ untuk jangka waktu 1 tahun, dan $2 \mu \mathrm{g} / \mathrm{m}^{3}$ untuk jangka waktu 24 jam. Berdasarkan pengujian yang telah dilakukan DLH Kota Bogor, kadar timbal yang terukur pada tahun 2015 sebesar $0,02 \mu \mathrm{g} / \mathrm{m}^{3}$; pada tahun 2016 terukur sebesar $>0,05 \mu \mathrm{g} / \mathrm{m}^{3}$; dan pada tahun 2018 terukur sebesar $40 \mu \mathrm{g} / \mathrm{m}^{3}$. Dari gambar 12 dapat dilihat bahwa terjadi peningkatan cukup signifikan dalam jangka waktu tahun 2016 hingga 2018.

Kontribusi pencemar terbesar berasal dari emisi gas buangan kendaraan bermotor, industri, pembangkit listrik dan kegiatan rumah tangga. Menurut Gusnita (2012) polusi Pb berasal dari hasil samping pembakaran yang kurang sempurna dalam mesin kendaraan bermotor. Semakin kurang sempurna proses pembakaran dalam mesin kendaraan bermotor, maka semakin banyak jumlah $\mathrm{Pb}$ yang akan di emisikan ke udara. Pihak Pertamina Persero masih memperbolehkan penggunaan $\mathrm{Pb}$ sebagai bahan tambahan pada proses pembuatan $\mathrm{BBM}$ jenis pertamax maksimal sebesar 0,013 g/L. Jenis BBM yang sudah tidak menggunakan $\mathrm{Pb}$ sama sekali adalah premium. Timbal bersifat karsinogenik, dapat menyebabkan mutasi, terurai dalam jangka waktu yang lama dan tokisisitasnya yang tidak berubah. 


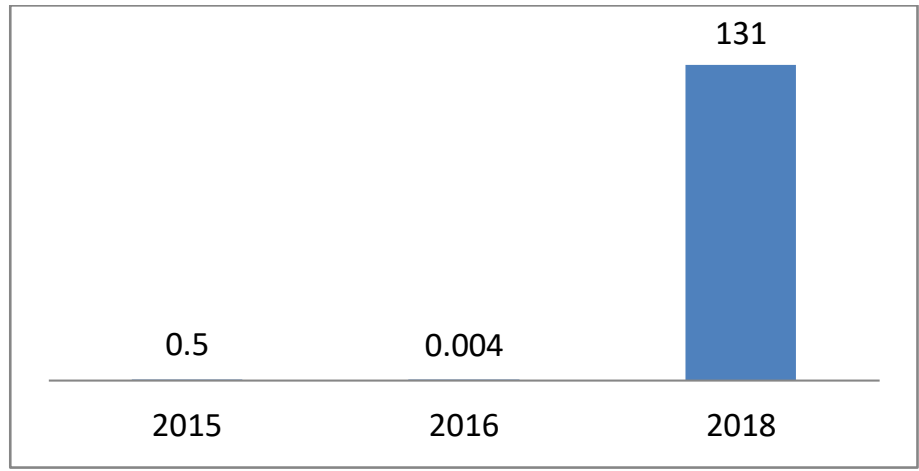

Gambar 13. Kandungan udara ambien $\mathrm{H}_{2} \mathrm{~S}$ pada tahun 2015-2018 Sumber: DLH Kota Bogor 2018

Baku mutu $\mathrm{H}_{2} \mathrm{~S}$ yang ditetapkan oleh DLH adalah sebesar 24 ppm. Pada pengukuran tahun $2015 \mathrm{H}_{2} \mathrm{~S}$ yang terukur sebesar $0,5 \mu \mathrm{g} / \mathrm{m}^{3}$; pada tahun 2016 terukur sebesar >0,004 ppm; dan pada tahun 2018 terukur sebesar $131 \mathrm{ppm}$. Dari gambar 13 dapat dilihat bahwa terjadi penurunan konsentrasi ambien $\mathrm{H}_{2} \mathrm{~S}$ dalam jângka waktu 2015 hingga 2016 namun mengalami peningkatan yang signifikan dalam jangka waktu 2016 hingga 2018. Hidrogen sulfida adalah gas yang tidak berwarna, beracun, mudah terbakar dan berbau busuk. Hidrogen sulfida bisa menjadi fatal jika konsentrasinya 500-1000 ppm, namun konsentrasi yang lebih rendah sebesar 10-500 ppm dapat menyebabkan berbagai macam gejala gangguan pernapasan (Doujaiji 2010). Secara alami gas H2S berasal dari gunung berapi, belerang, ventilasi bawah, rawa-rawa, dan badan air yang tidak mengalir serta minyak mentah dan gas alam. $\mathrm{H}_{2} \mathrm{~S}$ juga berasal dari saluran pembuangan limbah eair/padat perkotaan, pabrik pengolahan limbah, pabrik pupuk, dan pabrik pulp dan kertas. Sumber-sumber industri hidrogen sulfida termasuk kilang minyak, pabrik gas alam, pabrik petrokimia, pabrik pengolahan makanan, dan penyamakan kulit. Dibutuh kan kajian lebih lanjut mengenai sumber $\mathrm{H}_{2} \mathrm{~S}$ di area Lingkar Luar Kebun Raya Bogor ini.

Perubahan sistem arah transportasi di Lingkar Luar Kebun Raya Bogor ini selain menimbulkan peningkatan pada jumlah kendaraan, meningkat pula konsentrasi beberapa zat dan senyawa ambien. Keadaan ambien pada satu titik, yaitu titik Tugu Kujang memiliki konsentrasi $\mathrm{Pb}$ dan $\mathrm{H}_{2} \mathrm{~S}$ yang sudah di atas baku mutu. Sayangnya DLH Kota Bogor pada tahun 2018 hanya melakukan pengukuran di Tugu Kujang. Titik pengukuran lain yang berpotensi di area Gingkar Luar Kebun Raya Bogor yaitu persimpangan mall BTM, Pasar Bogor, persimpangan SMAN 1 Bogor, Balaikota, persimpangan YONIF, dan Lapangan Sempur. Diharapkan kedepannya titik pengukuran bisa diperbanyak agar data dapat diketahui lebih bersifat mewakili.

Dengan meningkatnya konsentrasi polutan di ambien maka perlu dílakukan rekayasa sistem untuk mengurangi polusi. Salah satunya dengan cara rekayasa vegetasi yang mampu mengurangi polusi. Vegetasi yang ditanam merupakan vegetasi yang memilki kondisi fisik yang sesuai sebagai penyerap polusi serta memiliki toleransi terhadap polusi itu sendiri. 


\section{Kondisi Umum Jalur Pedestrian}

Jalur pedestrian sepanjang Jalan Lingkar Luar Kebun Raya Bogor merupakan sebuah fasilitas Kota Bogor dimana masyarakat Kota Bogor dapat melakukan aktivitas di atasnya, atau menjadi sarana dalam melakukan aktivitas mereka sendiri yaitu sebagai akses perpindahan dari satu tempat ke tempat yang lain. Jalur pedestrian ini meliputi jalan untuk pejalan kaki, jalur sepeda, dan jalur hijau. Namun untuk jalur hijau dan jalur sepeda, keberadaannya tidak merata dan hanya ada di sebagian tapak.

Jalur pedestrian ini memiliki fasilitas antara lain lampu, marka jalan, bangk $\overline{\bar{u}}$, tempat sampah, ubin tekstur pemandu, dan bollard dengan kelengkapan berbeda di setiap bagian jalur. Lebar jalur pedestrian memiliki variasi dari yang tersempit yaitu sisi luar Jalan Otista yaitu 0,8 hingga 1 meter, sampai yang terlebar adalah sisi dalam Jalan Pajajaran dengan total lebar 7 meter.

\section{Data Pengguna Jalur Pedestrian}

Menurut penelitian sebelumnya (Irianti 2010), secara garis besar, penggūna pedestrian di sepanjang Jalan Lingkar Luar Kebun Raya Bogor jenis kelamï nya adalah laki-laki sebanyak $47 \%$ dan perempuan sebanyak $52,5 \%$. Kemuđ̃ian $40 \%$ atau kelompok terbesar dari pengguna adalah yang berada pada kelompok usia 10-20 tahun atau anak-anak dan remaja. Asal dari pengguna, sebagian besar dari pengguna adalah masyarakat lokal atau berasal dari Kota Bogor yaitu sebesar 92,5\%. Tingkat pendidikan dari pengguna sebanyak 47,5\% adalah masyarakat dengan tingkat pendidikan terakhir SMA/sederajat, dan penggena yang banyak ditemui di tapak adalah pelajar yaitu sebanyak $30 \%$ dan mahasiswa sebanyak $22,5 \%$.

Dari data tersebut, dapat diketahui bahwa jalur pedestrian ini merupakan fasilitas yang penting bagi masyarakat Kota Bogor itu sendiri, bukan bagi wisatawan yang berasal dari luar Kota Bogor. Kemudian walaupun pengguna terbesar adalah anak-anak dan remaja, namun pada tapak juga terdapat pengguna dari kelompok usia yang mencakup semua kelompok umur hingga dengan jumlah terkecil yaitu pengguna yang berumur diatas 50 tahun sebesar 7,5\%. Sehingga dapat disimpulkan jalur pedestrian ini dapat dinikmati oleh berbagai kalangan masyarakat di Kota Bogor.

\section{Kondisi Umum Jalur Hijau}

OUntuk memudahkan dalam pengambilan data, Jalan Lingkar Luar Kebun Raya dikelompokkan menjadi beberapa segmen. Segmen dibagi berdasarkan namajalan sementara jalur hijau dibagi menjadi segmen luar (B) dan segmen dalam(A). Pembagian diilustrasikan pada gambar 14 . 


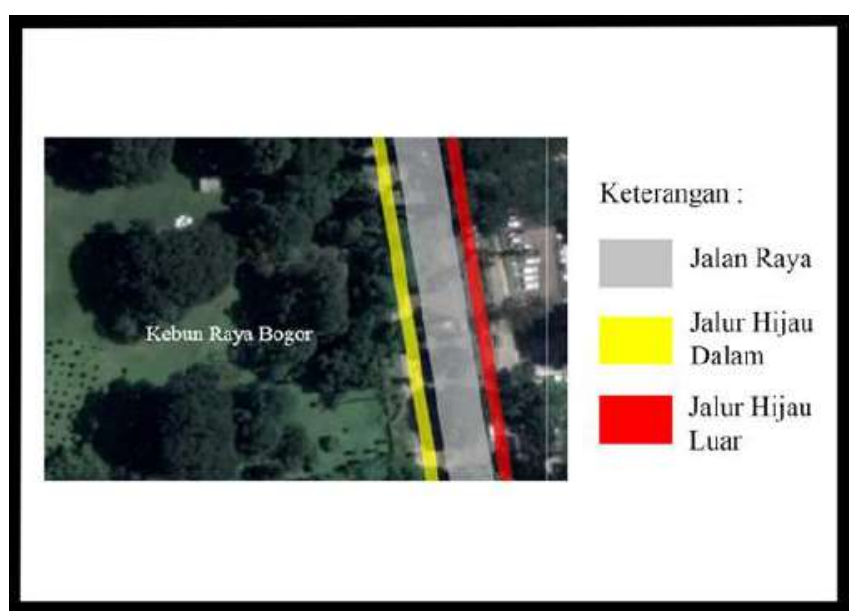

Gambar 14. Pembagian segmen Jalan Lingkar Luar Kebun Raya Bogor Sumber: Google Maps, 2018

\section{Jalan Pajajaran}

Jalan Pajajaran memiliki jalur hijau di kedua segmen yaitu segmen A dan segmen B. Pada segmen A jalur hijau terdapat di dua sisi dengan susunan jalur hijau dalam, pedestrian, jalur sepeda dan jalur hijau luar yang langsung berbatasn dengan jalan. Jenis vegetasi yang terdapat di jalur hijau Jl. Pajajaran ini terdidri đari komposisi pohon, perdu, semak, dan ground cover. Potongan dari Jl. Pajajran ditampilkan dalam Gambar 15.

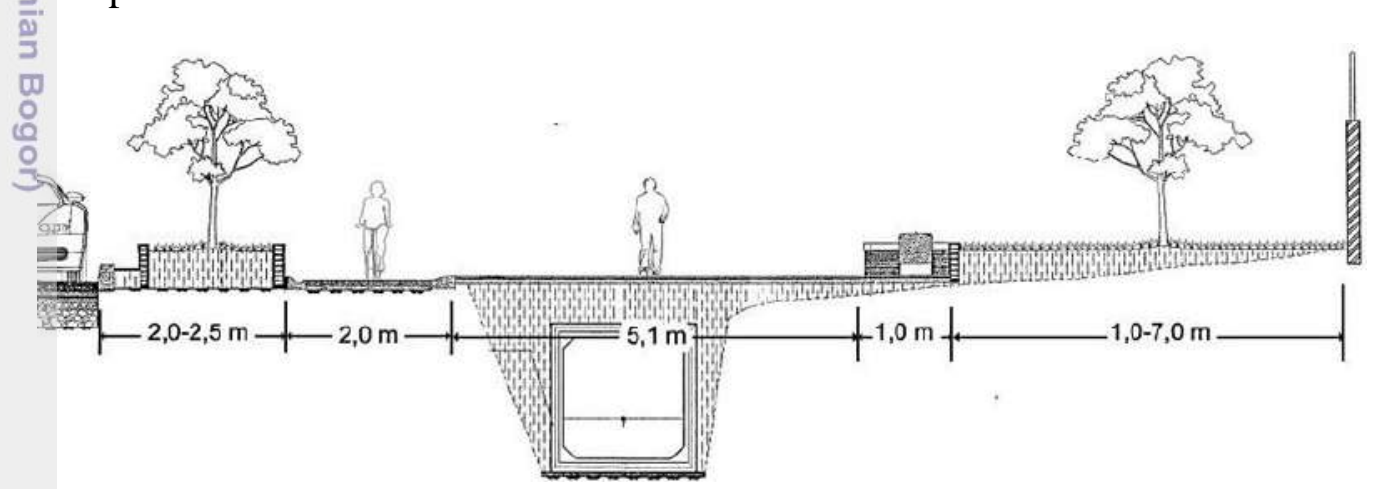

(a)

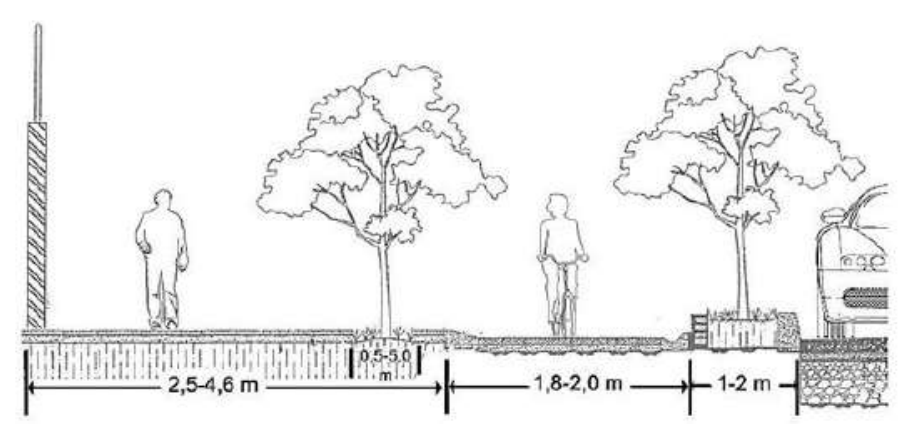

(b)

Gambar 15. Bentuk potongan di Jl. Pajajaran segmen A (a) dan segmen B (b) Sumber : DBSMA 2016 
Pada jalur hijau Jl. Pajajaran segmen B, jalur hijau hanya berupa tegakan pohon dengan kombinasi semak di beberapa titik. Jalur pedestrian di Jl. Pajajran segmen B berbatasan dengan kawasan ekonomi yang terdiri dari pusat perbelanjaan, kampus, nursery, rumah sakit, dan hotel.

Persentase jumlah pohon yang berada di Jl. Pajajaran terdiri dari pohon mahoni (Sweetenia macrophylla) sebanyak 48,1\%; pohon tanjung (Mimusop elengi) sebanyak 22,8\%; pohon damar (Agathis damara) sebanyak 18,4\%; pohon ketapang kencana (Terminalia mantaly) sebanyak 6,0\%; pohon cempaka (Michelia champaca) sebanyak 3,6\%; pohon kapuk (Ceiba petandra) sebanyak 1,8\%; pohon angsana (Pterocarpus indicus) sebanyak 0,6\%; pohon beringin (Ficus benjamina) sebanyak 0,6\%; pohon sempur (Dillenia indica) sebanyak 0,6\%; pohon nangka (Artocarpus indicus) sebanyak 0,6\%; dan pohon flamboyan (Delonix regia) sebanyak 0,6\%. Data lebih lengkapnya ditampilkan pada Tabel 9 beriku五 ini. Karakter lanskap Jl. Pajajaran dibentuk dari dominasi pohon mahoni

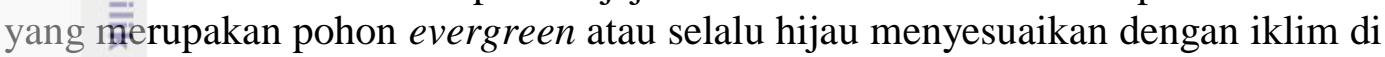
tapak. \#nalisis keragaman vegetasi menurut Shannon-Wiener, jenis pohon yang berda di Jl. Pajajaran memiliki nilai 1,58 yang masuk dalam kategori keragaman sedang

Tabel 9. Jenis dan jumlah pohon pada Jl. Pajajaran

\begin{tabular}{llcc}
\hline Namadatin & Nama Lokal & Jumlah & Persentase \\
\hline Agathis damara & Damar & 14 & $18,4 \%$ \\
Artocarpus heterophillus & Nangka & 1 & $0,6 \%$ \\
Ceiba Betandra & Kapuk & 3 & $1,8 \%$ \\
Cupresus papuana & Cemara gembel & 10 & $6,0 \%$ \\
Delonîx regia & Flamboyan & 1 & $0,6 \%$ \\
Dillenia indica & Sempur & 1 & $0,6 \%$ \\
Ficus benjamina & Beringin & 1 & $0,6 \%$ \\
Michelia champaca & Cempaka & 6 & $3,6 \%$ \\
Mimusop elengi & Tanjung & 38 & $22,8 \%$ \\
Pterocarpus indicus & Angsana & 1 & $0,6 \%$ \\
Switenia macrophylla & Mahoni & 80 & $48,1 \%$ \\
Terminalia mantaly & Ketapang kencana & 10 & $6,0 \%$ \\
\hline \multicolumn{2}{c}{ Total } & 166 & $100,0 \%$ \\
\hline
\end{tabular}

Sumber : survey lapang

\section{Jl. Otto Iskandardinata}

Jl. Otto Iskandardinata memiliki jalur hijau di kedua segmennya. Pada segmen A jalur hijau terletak ditengah jalur pedestrian. Tidak ada dinding pembatas antara tegakan pohon dengan jalur pedestrian. Komposisi jalur hijau hanyá terdiri dari tegakan pohon dengan jarak tidak terlalu dekat. Pada segmen B kondisi jalur hijau serupa dengan segmen A. Jalur hijau berupa terdiri dari tegakan pohon yang berada di tengah jalur pedestrian. 


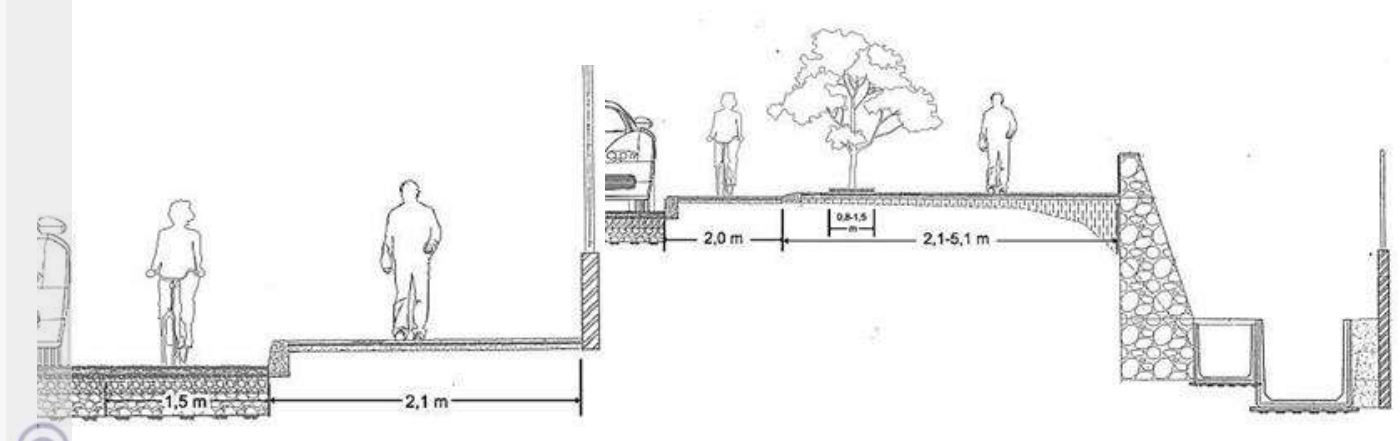

(a)



(c)

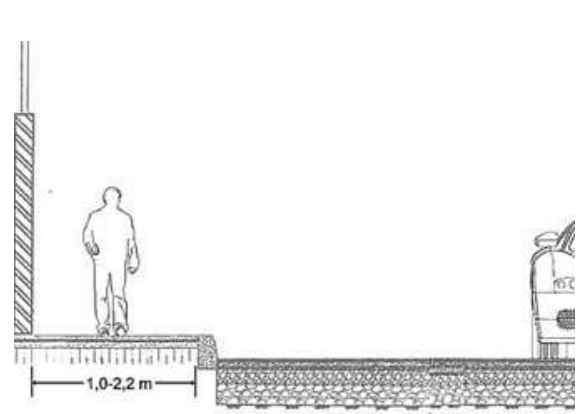

(d)

Gambar 16. Bentuk potongan Jl. Otto Iskandardinata pada segmen A (a dan b) dan segmen B (c dan d)

Sumber : DBSMA 2016

Persentase jumlah pohon pada Jl. Otto Iskandardinata terdiri dari pohon aren (Arenga pinata) sebanyak 23,2\%; pohon angsana (Pterocarpus indicus) sebanyak 18,6\%; pohon damar (Agathis damara) sebanyak 13,9\%; pohon tanjung (Mimusop elengi) sebanyak 9,3\%; pohon ketapang kencana (Terminalia mantaly) sebanyak 9,3\%; pohon bungur (Lagerstomia speciosa) sebanyak 9,3\%; pohon bunga kupu-kupu (Bauhinia purpurea) sebanyak 4,6\%: pohon bisbul (Diospyros blancoi) sebanyak 4,6\%; pohon flamboyan (Delonix regia) sebanyak 2,3\%; pohon kenari (Canarium communne) sebanyak 2,3\%; dan pohon manga (Magnifera indica) sebanyak 2,3\%. Analisis keragaman vegetasi menurut Shannon-Wiener, jenis pohon yang berda di Jl. Otto Iskandardinata memiliki nilai 2.137 yang masuk dalam kategori keragaman sedang. Data lebih lengkapnya disajikan di Tabel 10 dibawah ini

Tabel 10. Jenis dan jumlah pohon pada Jl. Otto Iskandardinata

\begin{tabular}{llcc}
\hline Nama Latin & Nama Lokal & Jumlah & Persentase \\
\hline Agathis damara & Damar & 6 & $13,9 \%$ \\
Arenga pinata & Aren & 10 & $23 \%$ \\
Bauhinia purpurea & Bunga kupu-kupu & 2 & $4,6 \%$ \\
Canarium comunne & Kenari & 1 & $2,3 \%$ \\
Delonix regia & Flamboyan & 1 & $2,3 \%$ \\
Diospyros blancoi & Bisbul & 2 & $4,6 \%$
\end{tabular}


Lanjutan Tabel 10. Jenis dan jumlah pohon pada Jl. Otto Iskandardinata

\begin{tabular}{llcc}
\hline Lagerstomia speciosa & Bungur & 4 & $9,3 \%$ \\
Magnifera indica & Mangga & 1 & $2,3 \%$ \\
Mimusop elengi & Tanjung & 4 & $9,3 \%$ \\
Pterocarpus indicus & Angsana & 8 & $18,6 \%$ \\
Terminalia mantaly & Ketapang kencana & 4 & $9,3 \%$ \\
\hline \multicolumn{2}{l}{ Total } & 43 & $100,0 \%$ \\
\hline
\end{tabular}

Sumber : survey lapang

\section{Jl. Juanda}

Jl. Juanda hanya memiliki jalur hijau di segmen B. Jalur hijau berbentuk linear dengan batas yang jelas dengan komposisi semak dan groundcover di bawahinya. Segmen A hanya berupa jalur pedestrian dengan jalur sepeda.



(a)

(b)

Gambar 17. Bentuk potongan Jl. Juanda segmen A (a) dan segmen B (b) 인 Sumber : DBSMA 2016

Persentase jumlah pohon di Jl. Juanda terdiri dari pohon kenari (Canarium communne) sebanyak 64,4\%; pohon mahoni (Switenia macrophylla) sebanyak $11,1 \%$; pohon palem raja (Roystonea regia) sebanyak $8,8 \%$; pohon tanjung (Mimusop elengi) sebanyak 6,6\%; pohon palem putri (Vietchia merilii)sebanyak 4,4\% ; pohon nangka (Artocarpus heterophillus) sebanyak 3,3\%; dan pohon beringin (Ficus benjamina) sebanyak $1,1 \%$. Analisis keragaman vegetasi menurut Shannon-Wiener jenis pohon yang berda di Jl. Juanda adalah 1,34 yang masuk dalam kategori keragaman sedang. Data disajikan di Tabel 11 dibawah ini.

Tabel11. Jenis dan jumlah pohon pada Jl. Juanda

\begin{tabular}{|c|c|c|c|}
\hline NamaLatin & Nama Lokal & Jumlah & Persentase \\
\hline Artocarpus heterophyllus & Nangka & 3 & $3,2 \%$ \\
\hline Canarium communne & Kenari & 58 & $63 \%$ \\
\hline Ficus benjamina & Beringin & 1 & $1,0 \%$ \\
\hline Magnifera indica & Mangga & 1 & $1,0 \%$ \\
\hline Mimusóp elengi & Tanjung & 6 & $6,4 \%$ \\
\hline Phoenix roebelinii & Palem phoenix & 2 & $2,1 \%$ \\
\hline Roystonea regia & Palem raja & 8 & $8,6 \%$ \\
\hline Switenta macrophylla & Mahoni & 10 & $10,7 \%$ \\
\hline Veitchia merilii & Palem putri & 4 & $4,3 \%$ \\
\hline \multicolumn{2}{|c|}{ Total } & 93 & $100,0 \%$ \\
\hline
\end{tabular}




\section{Jl. Jalak Harupat}

Pada Jl. Jalak Harupat segmen A posisi jalur hijau berada di sisi jalur pedestrian dan membatasi dengan jalur sepeda. Pada segmen Jl. Pajajran B jalur hijau terdapat pada sisi kanan dan kiri jalur pedestrian. Pada sisi kanan, jalur hijau langsung berbatasan dengan jalan sedangkan jalur hijau kiri langsung berbatasan dengan pagar Kebun Raya Bogor. Pada segmen A jalur hijau berbentuk linear dengan batas yang jelas. Jalur hijau segmen A terdiri dari komposisi pohon, perdu, dan semak. Jalur jijau pada segmen B berbentuk linear hanya terdiri dari tegakan pohon disebelah jalur pedestrian.

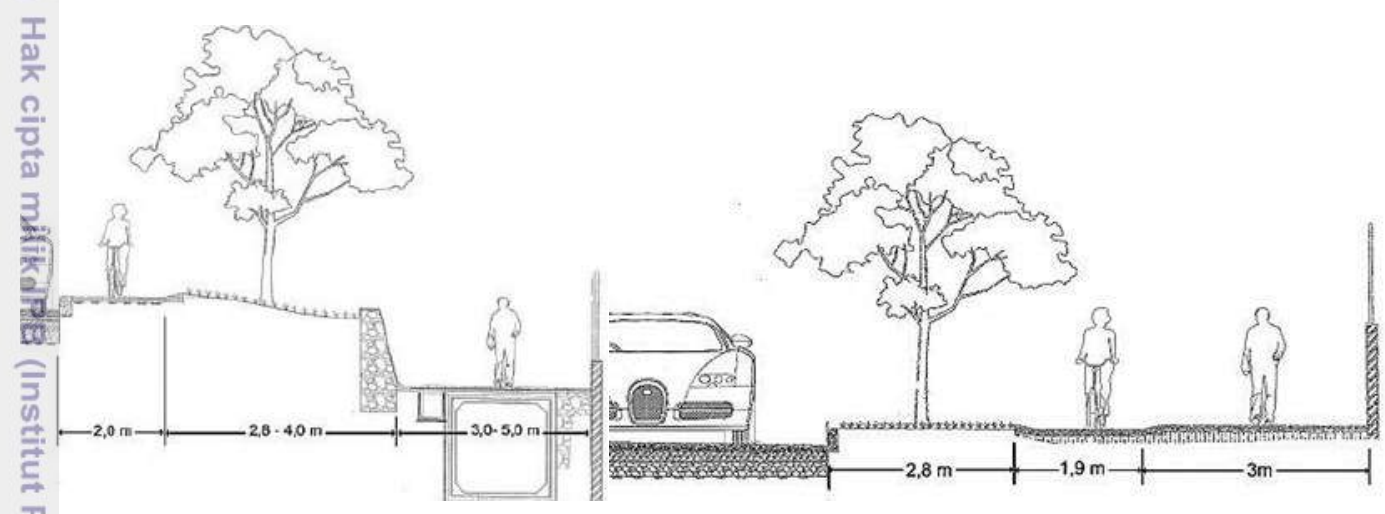

(a)

(b)

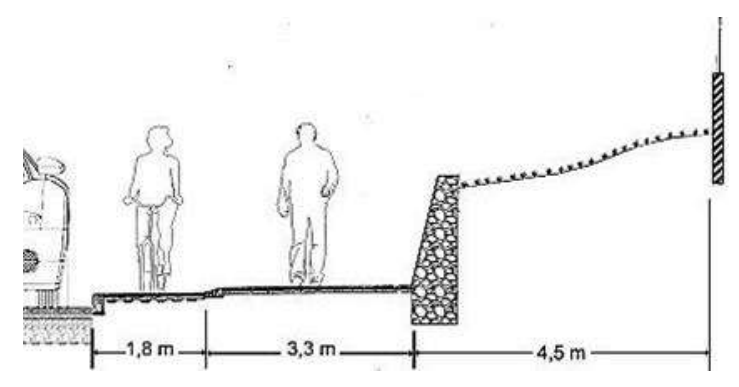

(c)

Gambar 18. Bentuk potongan jalur hijau segmen Jl. Jalak Harupat segmen A (a dan b) dan segmen B (c) sumber: DBSMA 2016

Persentase jumlah pohon di Jl. Jalak Harupat terdiri dari komposisi pohon mahoni (Switenia macrophylla) sebanyak 46,7\%; pohon tanjung (Mimusop elengi) sebanyak 29,8\%; pohon wali songo (Schefflera grandiflora) sebanyak 7.7\%; pohon nangka (Artocarpus heterophylus) sebanyak 5,1\%; pohon flamboyan (Delonix regia) sebanyak 3,8\%; pohon palem putri (Veithchia merilii) sebanyak 2.5\%; pohon damar (Agathis damara) sebanyak 1,2\%; pohon angsana (Pterocarpus indicus) sebanyak 1,2\% dan pohon kenari (Canarium communne) sebanyak $1,2 \%$. Analisis keragaman vegetasi menurut Shannon-Wiener jenis pohon yang berda di Jl. Jalak Harupat adalah 1,45 yang masuk dalam kategori keragaman sedang. Data yang lenkap disajikan di Tabel 12 dibawah ini 
Tabel 12. Jenis dan jumlah pohon pada J1. Jalak Harupat

\begin{tabular}{|c|c|c|c|}
\hline Nama Latin & Nama Lokal & Jumlah & Persentase \\
\hline Agathis damara & Damar & 1 & $1,2 \%$ \\
\hline Artocarpus heterophilus & Nangka & 4 & $5,1 \%$ \\
\hline Canarium communne & Kenari & 1 & $1,2 \%$ \\
\hline Delonix regia & Flamboyan & 3 & $3,8 \%$ \\
\hline Mimusop elengi & Tanjung & 23 & $29,8 \%$ \\
\hline Pterocarpus indicus & Angsana & 1 & $1,2 \%$ \\
\hline Schefflera grandiflora & Walisongo & 6 & $7,7 \%$ \\
\hline Switenia macrophylla & Mahoni & 36 & $46,7 \%$ \\
\hline Vietchïa merilii & Palem putri & 2 & $2,5 \%$ \\
\hline \multicolumn{2}{|c|}{ Total } & 77 & $100,0 \%$ \\
\hline
\end{tabular}

\section{Evaluasi Fisik Pohon sebagai Penyerap dan Penjerap Polusi}

J Hasil analisa menggunakan metode skoring terhadap pohon yang memiliki ciri fisid yang sesuai. Pohon penyerap polusi gas yang baik memiliki kriteria fisik seperti pohon bertajuk padat, berdaun tipis, dan memiliki jumlah daun yang banyak. Pohon yang termasuk dalam kategori sangat sesuai adalah pohon kenari (Canarium comunne), pohon flamboyan (Delonix regia), pohon angsana (Pteroếarpus indicus), pohon ketapang kencana (Terminalia mantaly), pohon tanjung (Mimusop elengi), dan pohon mahoni (Switenia macrophylla). Data yang lebih lengkap disajikan pada Tabel 13 dibawah ini. Penilaian lengkap disajikan pada Lampiran 3.

Tabel 13. Daftar persentase pohon penyerap polusi gas

\begin{tabular}{llcc}
\hline Namadain & Nama Lokal & Persentase & Keterangan \\
\hline Canarium comunne & Kenari & $91,6 \%$ & Sangat sesuai \\
Delonix regia & Flamboyan & $91,6 \%$ & Sangat sesuai \\
Pterocarpus indicus & Angsana & $91,6 \%$ & Sangat sesuai \\
Terminalia mantaly & Ketapang kencana & $91,6 \%$ & Sangat sesuai \\
Mimusop elengi & Tanjung & $91,6 \%$ & Sangat sesuai \\
Switenia macrophylla & Mahoni & $83,3 \%$ & Sangat sesuai \\
Bauhinia purpurea & Bunga kupu-kupu & $83,3 \%$ & Sangat sesuai \\
Cupresus papuana & Cemara gembel & $83,3 \%$ & Sangat sesuia \\
Ficus benjamina & Beringin & $75 \%$ & Sesuai \\
Lagerstomia speciosa & Bungur & $75 \%$ & Sesuai \\
Ceibapentandara & Kapuk & $75 \%$ & Sesuai \\
Diospyros blancoi & Bisbul & $66,7 \%$ & Sesuai \\
Arenga pinata & Aren & $66,7 \%$ & Sesuai \\
Artocarpus heterophylus & Nangka & $58,3 \%$ & Kurang sesuai \\
Dillenia indica & Sempur & $58,3 \%$ & Kurang sesuai \\
Magnifera indica & Mangga & $58,3 \%$ & Kurang sesuai \\
Michétia champaca & Cempaka & $58,3 \%$ & Kurang sesuai \\
Agathis damara & Damar & $50 \%$ & Kurang sesuai \\
Roystonea regia & Palem raja & $41,7 \%$ & Kurang sesuai \\
Schefftera grandiflora & Walisongo & $41,7 \%$ & Kurang sesuai \\
Phoenix robelini & Palem phoenix & $33,4 \%$ & Tidak sesuai \\
Veitchia merilli & Palem putri & $33,4 \%$ & Tidak sesuai \\
\hline
\end{tabular}


Pohon dengan kategori sangat sesuai memiliki ciri fisik beragam, yaitu memiliki daun yang tipis, banyaknya jumlah daun, dan tajuk yang padat. Pohon yang memiliki daun yang tipis juga memiliki kemampuan menyerap polusi yang baik. Daun pada suatu tanaman yang memiliki ketebalan yang tipis lebih mudah menyerap polutan gas daripada daun yang tebal. Daun yang tebal umumnya memiliki jaringan dermis yang tebal sehingga sulit untuk di tembus oleh polutan berbentuk gas. Semakin padat dan banyak jumlah daunnya maka semakin banyak jumlah luas permukaan daunnya. Hal ini berhubungan dengan jumlah stomata yang semakin banyak pada permukaan daun sehingga lebih banyak volume polusi gas yang terserap. Hal ini sesuai dengan penelitian yang dilakukan oleh Astra et al., (2004) yang menyatakan bahwa semakin tinggi kerapatan stomata, semakin tipis ketebalan daun dan semakin kecil berat jenis daun maka semakin tinggi kemampuan dalam menyerap gas $\mathrm{NO}_{2}$. Selain itu, struktur vegetasi yang makin padat jarak tanam antar pohonnya pada suatu RTH maka kemampuan RTH tersebut dapat melakukan proses absorbsi terhadap polusi yang semakin baik. Menurut penelitian Carpenter et al., (1975) tanaman dapat mengurangi polutan $\overline{\bar{y}}$ dara melalui proses oksigenasi, yaitu proses pelepasan oksigen ke atmosfer, dan dilusi, yaitu pencampuran udara tercemar dengan udara bersih. Ketika udara yang tercemar mengalir di dalam dan sekitar tanaman dan melewati udara bersih dan beroksigen, terjadi pencampuran antara udara yang tercemar dengan udara bersih sehingga konsentrasi zat pencemar udara berkurang.

Hasil analisa menggunakan metode skoring terhadap pohon yang sessuai karena meiliki kempuan penjerap polusi partikel yang baik memiliki ciri fisik Ștruktur permukaan daun yang kasar/berbulu/berbentuk jarum, memiliki tajuk padat, memiliki tekstur batang dan ranting yang kasar, dan ranting yang padat. Pohon yang termasuk kategori sangat sesuai adalah pohon bisbul (Diospyros blancoi) dan pohon bungur (Lagerstomia speciosa). Data yang lebih lengkap disajikan pada Tabel 14 dibawah ini. Penilaian lengkap disajikan pada Lampiran 4.

Tabel 14. Daftar persentase kesesuaian pohon penjerap polusi partikel

\begin{tabular}{|c|c|c|c|}
\hline Nama Latin & Nama lokal & Persentase & Keterangan \\
\hline Diospyros blancoi & Bisbul & $90 \%$ & Sangat sesuai \\
\hline Lagerstomia speciosa & Bungur & $85 \%$ & Sangat sesuai \\
\hline Cupresus papuana & Cemara gembel & $81,5 \%$ & Sangat sesuai \\
\hline Switenia macrophylla & Mahoni & $80 \%$ & Sesuai \\
\hline Pterocarpus indicus & Angsana & $80 \%$ & Sesuai \\
\hline Schefflera grandiflora & Walisongo & $80 \%$ & Sesuai \\
\hline Magnifera indica & Mangga & $75 \%$ & Sesuai \\
\hline $\bar{B}$ auhinia purpurea & Bunga kupu-kupu & $75 \%$ & Sesuai \\
\hline Canarium comunne & Kenari & $70 \%$ & Sesuai \\
\hline Dillenia indica & Sempur & $70 \%$ & Sesuai \\
\hline Michelia champaca & Cempaka & $65 \%$ & Sesuai \\
\hline Bhoenix roebelinii & Palem phoenix & $65 \%$ & Sesuai \\
\hline Mimusop elengi & Tanjung & $65 \%$ & Sesuai \\
\hline
\end{tabular}


Lanjutan Tabel 14. Daftar Persentase kesesuaian pohon penjerap polusi partikel

\begin{tabular}{lllc}
\hline Artocarpus heterophylus & Nangka & $65 \%$ & Sesuai \\
Terminalia mantaly & Ketapang kencana & $55 \%$ & Sesuai \\
Ceiba pentadra & Kapuk & $55 \%$ & Sesuai \\
Delonix regia & Flamboyan & $55 \%$ & Sesuai \\
Agathis damara & Damar & $50 \%$ & Kurang sesuai \\
Ficus benjamina & Beringin & $50 \%$ & Kurang sesuai \\
Arenga pinata & Aren & $45 \%$ & Kurang sesuai \\
Roystonea regia & Palem raja & $30 \%$ & Tidak sesuai \\
Veitchia merilii & Palem putri & $30 \%$ & Tidak sesuai \\
\hline
\end{tabular}

$\frac{T}{\partial}$

Kriteria pohon yang dapat menjerap partikel dengan baik diantaranya harus memiliki permukaan daun yang kasar, berlekuk, berbulu dan bertrikoma, daun ב̇ang menjarum dan juga melebar, tajuk tanaman yang padat dan rapat, tekstu kulit batang dan ranting yang kasar serta berduri, dan kepadatan ranting yang rapat. Permukaan daun yang berbulu dan bertrikoma mampu menjerap partikel lebih banyak daripada permukaan daun yang tidak berbulu dan bertrikōma. Partikel polutan yang tersebar di udara dapat menempel pada bulu dan trikoma yang terletak pada permukaan daun. Menurut Tambaru (2012) karakteristik daun yang dapat dijadikan acuan dalam pemilihan jenis pohon untuk penghijauan di perkotaan khususnya lokasi terpolusi yaitu permukaan daun licin, mengkfilap, berbulu kasar dan tepi daun bergelombang karena mampu menyerap partikej-partikel debu. Daun yang menjarum dan melebar lebih efektif dalam menyerap polutan karena memiliki luas permukaan daun yang lebih besar. Pohon yang memiliki masa tajuk yang massif dan rapat dapat menjerap partikel lebih besar dan efektif daripada masa tajuk yang terbuka. Selain itu permukaan yang kasar pada struktur batang dan ranting juga berpengaruh terhadap kemampuan pohon dalam menjerap partikel. Ranting dan batang pada pohon yang memiliki struktur permukaan yang kasar dapat menjerap partikel lebih baik daripada pohon yang memiliki struktur permukaan. Kepadatan ranting yang rapat pada suatu pohon juga lebih efektif dalam menjerap partikel.

\section{Pengukuran Air Pollution Tolerance Index (APTI)}

Toleransi tanaman terhadap bahan pencemar dapat dilihat dari beberapa parameter fisiologi yaitu asam askorbat, kandungan krorofil total, $\mathrm{pH}$ ekstrak daun, dan kadar air relatif (Singh et al. 1991). Terdapat satu spesies yang tidak dapat diambil contoh daunnya yaitu palem raja (Roystonea regia) karena tinggi pohontersebut mencapai belasan meter sehingga menyulitkan ketika pengabilan contoh, Hasil analisis beberapa parameter fisologi tersebut pada pohon yang berada di Lingkar Luar Kebun Raya Bogor ditampilkan pada Tabel 15 dibawah ini. 
Tabel 15. Kandungan asam askorbat, total klorofil, $\mathrm{pH}$, dan kadar air relatif pada daun setiap jenis pohon di Lingkar Luar Kebun Raya Bogor

\begin{tabular}{|c|c|c|c|c|}
\hline Nama Latin & $\begin{array}{c}\text { Asam } \\
\text { Askorbat } \\
(\mathrm{mg} / \mathrm{g})\end{array}$ & $\begin{array}{c}\text { Total } \\
\text { Klorofil } \\
(\mathrm{mg} / \mathrm{g})\end{array}$ & $\mathrm{pH}$ & $\begin{array}{c}\text { Kadar air } \\
(\%)\end{array}$ \\
\hline Agathis damara & 4.00 & 2.12 & 4.26 & 61.90 \\
\hline Arenga piñata & 4.00 & 6.59 & 5.60 & 71.72 \\
\hline Artocarpus heterophillus & 4.00 & 3.98 & 6.44 & 81.11 \\
\hline Bauhinia purpurea & 3.99 & 3.91 & 6.41 & 77.18 \\
\hline Ganarium comunne & 3.99 & 2.80 & 5.60 & 80.56 \\
\hline Eeiba petandra & 4.00 & 6.60 & 6.54 & 87.33 \\
\hline Cupressus papuana & 4.00 & 1.80 & 5.16 & 69.84 \\
\hline Delonix regia & 4.00 & 5.04 & 5.89 & 80.39 \\
\hline Dillenia indica & 4.00 & 1.67 & 5.44 & 92.90 \\
\hline Diospyros blancoi & 4.00 & 2.10 & 6.20 & 87.38 \\
\hline Ficus benjamina & 3.99 & 2.02 & 7.40 & 64.32 \\
\hline Lagerstomia speciousa & 4.00 & 3.19 & 6.12 & 91.74 \\
\hline$\overline{\bar{M}}$ agnifera indica & 3.99 & 2.50 & 5.86 & 65.20 \\
\hline Michelia champaca & 4.00 & 3.69 & 6.12 & 76.82 \\
\hline Mimusoph elengi & 3.99 & 5.14 & 5.73 & 84.62 \\
\hline Phoenix robelinii & 3.99 & 2.02 & 5.86 & 86.20 \\
\hline Pُterocarpus indicus & 4.00 & 5.14 & 6.01 & 73.80 \\
\hline Roystonea regia* & - & - & - & - \\
\hline Schefflera grandiflora & 4.00 & 3.89 & 6.26 & 66.29 \\
\hline Switenia macrophylla & 4.00 & 3.70 & 5.89 & 86.05 \\
\hline Ferminalia mantaly & 4.00 & 4.22 & 5.00 & 67.88 \\
\hline Veitchia merilii & 4.00 & 2.69 & 6.02 & 97.02 \\
\hline
\end{tabular}

*Tidak dilakukan pengukuran karena kesulitan secara teknis dalam pengambilan sampel daun

\section{Asam Askorbat}

Berdasarkan hasil penelitian, pengaruh polusi udara terhadap kandungan asam askorbat pada tanaman cenderung sama pada semua jenis. Semakin tinggi kandungan asam askorbat maka tanaman semakin toleran terhadap polusi udara. Hal ini diungkapkan Rai. et al. 2013, bahwa tanaman yang toleran terhadap polusi udara memiliki kandungan asam askorbat yang tinggi karena asam askorbat memiliki fungs sebagai anti oksidan atau reduktor kuat yang dapat mencegah terjadinya reaksi oksidasi. Jika reaksi oksidasi sampai berlangsung makan akan terbentuk senyawa yang dapat meracuni tanaman. Berkurangnya mineral, salah satunya asam askorbat merupakan salah satu faktor yang bertanggung jawab dalam pembentukan ROS (Reactive Oxygen Species). ROS merupakan molekul reaktif yang sangat kecil yang dapat memnyebabkan kerusakan struktur sel tumbuhan. Oleh karena asam askorbat menurunkan konsentrasi ROS pada daun maka peningkatan kandungan asam askorbat pada daun akan meningkatkan pula toleransi tanaman terhadap polusi udara (Tripathi et al. 2007). 
Hasil penelitian yang tidak berbeda nyata antar jenis tanaman dikarenakan lokasi tumbuh dan lokasi pencemaran. Menurut Klumpp et al. 2000, kontaminasi tanah dan polusi udara telah diketahui dapat menyebabkan penurunan kandungan asam askorbat pada tanaman Tibouchina pulchra.

\section{Klorofil}

Kandungan klorofil total yang paling tinggi terdapat pada kapuk (Ceiba petandra) yaitu sebebsar 6.60, sedangkan yang paling kecil terdapat pada sempur (Dillenia indica) yaitu sebesar 1.67. Semakin tinggi kandungan klorofil pada suatu tanaman maka semakin toleran tanaman tersebut terhadap polusi udara. Kandūngan klorofil yang lebih tinggi diduga mendukung toleransi tumbuhan terhadâp polutan. Hal yang serupa dikemukakan oleh Carter dan Knapp (2001) yang menyebutkan bahwa bahan pencemar dapat menginduksi pengurangan klorofï. Pencemaran udara dapat menimbulkan nekrosis dan klorosis yang melibatkan mekanisme kerusakan klorofil. Menurut Thripathi et al. (2007), kandungan klorofil akan menurun selama produksi ROS pada kloroplas di bawah kondisi yang tidak mendukung. Kandungan klorofil yang menurun akan berpengaruh pada berkurangnya laju fotosintesis (Hidayati, 2009).

pH

Derajat keasaman atau $\mathrm{pH}$ yang paling tinggi terdapat pada beringin (Ficus benjanina) sebesar 7.40yang berarti basa lemah, sementara $\mathrm{pH}$ yang paling rendahterdapat pada damar (Agathis damara) sebesar 4.26. Kandungan nilai $\mathrm{pH}$ yang ditinggi diketahui dapat meningkatkan toleransi terhadap polusi. Derajat keasaman daun dapat menjadi indikator toleransi tanaman karena $\mathrm{pH}$ berperan penting dalam berbagai reaksi fisiologi tanaman (Dwiputri, 2015).

\section{Kadar Air}

Kandungan kadar air yang paling besar terdapat pada palem putri (Veitchia merilii) yaitu sebesar $97,02 \%$, sementara yang paling rendah terdapat pada damar (Agathis damara) yaitu sebesar 61,90\%. Polutan udara dapat meningkatkan permeabilitas sel yang disebabkan oleh kehilangan air dan terlarutnya bahan nutrisi, akibatnya daun cepat mengalami senescene (Masuch et al. 1988 dalam Singh et al. 1991) sehingga tanaman yang memiliki kandungan air relative tinggi dalam kondisi terpapar polusi akan lebih toleran terhadap polutan.

\section{Toleransi Tanaman terhadap Pencemar Udara}

OMenurut Sing et al. (1991) kandungan asam askorbat total, klorofil total, $\mathrm{pH}$, dan kadar air daun yang diformulasikan ke dalam nilai APTI, merupakan parameter fisiologi tanaman yang dapat digunakan untuk menentukan tingkat toleranși tanaman terhadap pencemar udara. Perubahan nilai APTI dapat terjadi jika ađa perubahan pada komponen APTIyaiyu asam askorbat, klorofil, $\mathrm{pH}$ dan kadar-air. Nilai toleransi tanaman berdasarkan nilai APTI disajikan pada tabel 16 dibawah ini 
Tabel 16. Toleransi tanaman terhadap pencemaran udara berdasarkan nilai APTI

\begin{tabular}{|c|c|c|}
\hline Nama Latin & Nilai APTI & Tingkat Toleransi \\
\hline Ceiba petandra & 13.99 & Sedang \\
\hline Vietchia merilii & 12.89 & Sedang \\
\hline Mimusoph elengi & 12.80 & Sedang \\
\hline Lagerstomia speciousa & 12.66 & Sedang \\
\hline Switenia macrophylla & 12.44 & Sedang \\
\hline Delonix regia & 12.41 & Sedang \\
\hline Artocarpus heterophillus & 12.28 & Sedang \\
\hline Dillenia indica & 12.13 & Sedang \\
\hline Diospyros blancoi & 12.06 & Sedang \\
\hline Arenga piñata & 12.05 & Sedang \\
\hline Bterocarpus indicus & 11.84 & Sensitif \\
\hline$\widehat{B}$ auhinia purpurea & 11.83 & Sensitif \\
\hline Phoenix roebelini & 11.76 & Sensitif \\
\hline Michelia champaca & 11.61 & Sensitif \\
\hline$\overline{\bar{C}}$ anarium commune & 11.41 & Sensitif \\
\hline Schefflera grandiflora & 10.68 & Sensitif \\
\hline Ferminalia mantaly & 10.48 & Sensitif \\
\hline Eicus benjamina & 10.19 & Sensitif \\
\hline Eupressus papuana & 9.76 & Sensitif \\
\hline Magnifera indica & 9.70 & Sensitif \\
\hline Agathis damara & 8.74 & Sensitif \\
\hline Roystonea regia* & - & - \\
\hline
\end{tabular}

Keterangan: Sensitif $\leq 12$, Sedang 12-16, Cukup toleran 17-20, Toleran $\geq 20$ (Singh et al. 1991)

Penentuan toleransi tanaman terhadap polusi udara berdasarkan kriteria Singh et al. (1991) untuk jenis pohon evergreen. Terdapat perbedaan pada nilai APTI yang diperoleh karena kandungan parameter indikator yang berbeda-beda pada setiap tanaman. Hal ini menunjukan kemampuan toleransi yang berbedabeda namun ketika nilai APTI dikategorikan hampir semua tanaman masuk kedalam tingkat toleransi sensitif. Hasil penelitian menunjukan bahwa satu spesies dengan tingkat toleransi sedang dan 20 dengan tingkat toleransi sensitif. Nilai APTI tertinggi terdapat pada pohon randu (Ceiba petandra) dengan jumlah 13.99 Sedangkan nilai terendah terdapat pada pohon damar (Agathis damara) dengan jumlah 8.74. Terdapat dua kelompok tingkat toleransi yaitu sedang dan sensitive. Jenis pohon tingkat toleransi sedang terdiri dari kapuk (Ceiba petandra), palem putri (Vietchia merilii), tanjung (Mimusoph elengi), bungur (Lagerstomia speciousa), mahoni (Switenia macrophylla), flamboyan (Delonix regia), nangka (Artocarpus heterophyllus), sempur (Dillenia indica), bisbul (Diospyros blancoi), dan aren (Arenga piñata). Sementara jenis pohon dengan tingkat toleransi sensitif adalah angsana (Pterocarpus indicus), kupu-kupu (Bauhinia purpurea), palem phoenix (Phoenix roebelinii), cempaka (Michelia champaca), kenari (Canarium commune), walisongo (Schefflera grandiflora), ketapang kencana (Terminalia 
mantaly), beringin (Ficus benjamina), cemara gembel (Cupressus papuana), mangga (Magnifera indica), dan damar (Agathis damara).

Berdasarkan pada hasil penelitian tidak ditemukan adanya spesies yang toleran, namun pada kenyataanya tanaman dapat tumbuh di area ini. Hal ini menandakan bahwa spesies dengan tingkat toleransi sedang dan sensitif masih bisa tumbuh di daerah yang berpolusi. Berdasarkan penelitian yang dilakukan oleh Dwiputri (2015), tanaman dengan tingkat toleransi sensitif masih bisa tumbuh di daerah industri yang berpolusi namun memiliki rasio pertumbuhan relatif yang rendah. Parameter yang diukur untuk menentukan rasio pertumbuhan relatif terdiri dari rata-rata pertambahan luas daun dalam jangka waktu tertentu. Hal ini menunjukan bahwa tanaman yang tidak toleran masih dapat tumbuh di daerah berpolusi tetapi laju pertumbuhannya tidak secepat tanaman yang toleran.

Pada penelitian ini, pengukuran nilai APTI hanya dilakukan pada satu lokasi yang terpolusi tanpa ada pembanding untuk spesies tanaman yang sama pada lôkasi yang berbeda. Menurut Garsed dan Rutter (1982) bahwa nilai APTI pada spesies tanaman yang sama dapat berbeda jika lokasi yang berbeda. Hal ini disebaЂkan oleh perbedaan konsentrasi polutan dan durasi tanaman terpapar polutan sehingga hasil penelitian ini hanya berlaku untuk mengetahui tingkat toleransi tanaman terhadap polusi udara di area terpolusi. Perlu adanya penelitian lanjutan untuk membandingkan nilai APTI pada spesies tanaman yang sama dengan variasi kondisi lingkungan yang berbeda sehingga dapat mengetahui perubăhan nilai APTI itu sendiri. Berdasarkan penelitian yang dilakukan oleh Agbaire dan Esiefarienrhe (2009) menunjukkan bahwa nilai APTI tanaman yang tumbuh di lokasi yang terkena polusi lebih tinggi dibandingkan dengan nilai APTI tanamân yang berada di lokasi terkontrol atau jauh dari aktifitas transportasi.

Tanaman dengan tingkat toleransi toleran dapat digunakan sebagai tanaman reduktor polutan sedangkan tanaman dengan tingkat toleransi sensitif dapat digunakan sebagai bioindikator lingkungan (Sigh dan Rao 1983). Dalam penelitian ini, semua spesies tanaman dapat digunakan sebagai bioindikator lingkungan karena termasuk kedalam tingkat toleransi toleran dan sensitif.. Tanaman sebagai bioindikator menunjukan bentuk reaksi tumbuhan terhadap bahan pencemar udara yang dapat teramati, meningkat selaras dengan tingkat pencemaran yang terjadi. Penurunan APTI bisa terjadi karena peningkatan kadar polusi udara. Hal ini sesuai dengan pernyataan Nugrahani dan Prasetyawati (2010) bahwa tanaman fitoindikator menunjukkan penurunan APTI dengan semakin meningkatnya kadar polutan udara sedangkan tanaman yang toleran terhadap polusioudara, menunjukkan peningkatan APTI pada lokasi terpolusi. Menurut penelitian yang dilakukan oleh Singsaas et al. (2003) tanaman memiliki respon terhadap polusi udara yang akan berdampak pada morfologi dan kandungan biokimia pada tanaman. Menurut Kozlowski dan Mudds (1975), adanya pencemaran udara dapat menimbulkan nekrosis dan klorosis yang melibatkan mekanisme kerusakan klorofil. Tanaman yang terkena polutan dengan konsentrasi rendah dapat menyebabkan terjadinya klorosis daun yang bersifat progesif dan senescense sedangkan tanaman yang terkena polutan dengan konsentrasi tinggi umumnya menyebabkan perlukaan yang tampak pada kematian, menjadi kering dan jaringan daun lokal memutih (Waryanti et al. 2015). Pada beberapa kasus, 
daun dapat diidentifikasi dengan gejalakerusakan yang ditumbulkan seperti $\mathrm{SO}_{2}$ yang menyebabkan klorosis di dalam urat daun, $\mathrm{NO}_{\mathrm{x}}$ menimbulkan spot hitam/ coklat tak teratur pada urat/tepi daun, sedangkan $\mathrm{O}_{3}$ menimbulkan bintik putih, kuning cokelat paa permukaan daun atas dan berkaitan dengan stomata (Udayana, 2004). Perlu adanya kajian lanjutan untuk mengetahui gejala kerusakan yang terjadi pada tanaman pada area Lingkar Luar Kebun Raya Bogor.

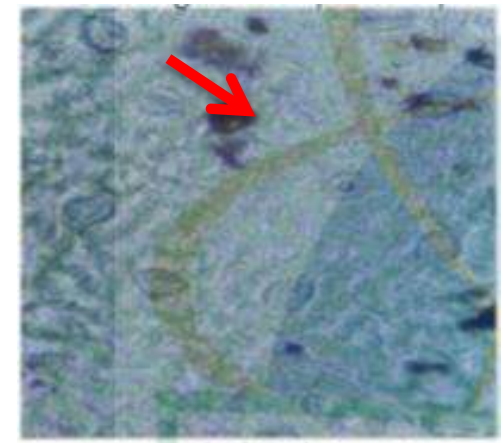

Gambar 19. Spot hitam gejala kerusakan daun angsana Sumber : Waryanti et al. 2015



Gambar 20. Nekrosis yang terjadi pada percobaan semak kategori sensitif pada tingkat pencemar yang berbeda

Sumber: Nugrahani dan Prasetyawati 2010

Waryanti et al. (2015) mengamati kerusakan mikroskopis yang terjadi pada daun pepohonan yang berapada pada kawasan terpolusi namun pada penelitian tersebut tida dilakukan pengukuran udara. Pada penelitian Nugrahani dan Prasetya (2010) tanaman yang digunakan diberikan perlakuan berbeda. Pelakuan itu meliputi pemberian tingkat pencemar yang beragam. Zat pencemar yang digunakan berupa $\mathrm{NO}_{\mathrm{x}}$ pada konsentrasi yang berbeda-beda. Hasil penelitian tersebut menyatakan bahwa kerusakan yang terjadi pada tanaman berbanding turus dengan tingkat konsentrasi $\mathrm{NO}_{\mathrm{x}}$. Semakin tinggi konsentrasi $\mathrm{NO}_{\mathrm{x}}$ yang diberikan makan tingkat persentase kerusakan daun semakin meningkat.

\section{Hubungan Fungsi Fisik dengan Toleransi Pohon Terhadap Polusi Udara}

Berdasarkan pada hasil penilaian keseuaian fisik sebagai penyerap polusi gas serta tingkat toleransi terhadap polusi udara, maka jenis pohon terbagi ke dalam lima kategori. Kategori tersebut terdiri dari sangat sesuai-sedang, sangat sesuai-sensitif, sesuai-sedang, sesuai-sensitif, kurang sesuai-sedang, kurang sèsuai-sensitif, tidak sesuai-sedang dan tidak sensuai sensitif. Data disajikan pada tabel 17. 
Tabel 17. Hubungan fungsi fisik Pohon sebagai penyerap gas dengan toleransi terhadap polusi udara

\begin{tabular}{|c|c|c|}
\hline Nama Latin & Pohon sebagai Penyerap Gas & APTI \\
\hline Canarium comunne & Sangat sesuai & Sensitif \\
\hline Delonix regia & Sangat sesuai & Sedang \\
\hline Pterocarpus indicus & Sangat sesuai & Sensitif \\
\hline Terminalia mantaly & Sangat sesuai & Sensitif \\
\hline Mimusop elengi & Sangat sesuai & Sedang \\
\hline Switenia macrophylla & Sangat sesuai & Sedang \\
\hline Bauhinia purpurea & Sangat sesuai & Sensitif \\
\hline Cupres̄us papuana & Sangat sesuai & Sensitif \\
\hline Ficus benjamina & Sesuai & Sensitif \\
\hline Lagerstomia speciosa & Sesuai & Sedang \\
\hline Ceibapentandra & Sesuai & Sedang \\
\hline Diospyros blancoi & Sesuai & Sedang \\
\hline Areng六pinata & Sesuai & Sedang \\
\hline Artocarpus heterophylus & Kurang sesuai & Sedang \\
\hline Dillenia indica & Kurang sesuai & Sedang \\
\hline Magnifera indica & Kurang sesuai & Sensitif \\
\hline Michetia champaca & Kurang sesuai & Sensitif \\
\hline Agathis damara & Kurang sesuai & Sensitif \\
\hline Roystonea regia & Kurang sesuai & - \\
\hline Schefftera grandiflora & Kurang sesuai & Sensitif \\
\hline Phoenix robelini & Tidak sesuai & Sensitif \\
\hline Veitchia merilli & Tidak sesuai & Sedang \\
\hline
\end{tabular}

\section{Kategori Sangat Sesuai-Sedang}

Pohon yang termasuk kedalam kategori sangat sesuai dengan tingkat toleransi sedang terdiri dari flamboyan (Delonix regia), tanjung (Mimusop elengi), dan mahoni (Switenia macrophylla). Jenis tanaman pada kategori ini berjumlah $53,29 \%$ dari total populasi yang ada. Jenis tanaman ini diharapkan dipertahankan karena memiliki potensi yang baik dalam menyerap polutan gas serta tingkat toleransi yang sedang.

\section{Kategori Sangat sesuai-sensitif}

Pohon yang termasuk kedalam kategori sangat sesuai dengan tingkat toleransi sensitif terdiri dari kenari (Canarium commune), angsana (Pterocarpus indicus), ketapang kencana (Terminalia mantaly), bunga kupu-kupu (Bauhinia purpurea), dan cemara gembel (Cupressus papuana). Jenis tanaman pada kategori ini berjumlah $25,32 \%$ dari total populasi yang ada. Jenis tanaman ini dapat dipertahankan karena memiliki potensi yang baik namun dalam penanamanya perlu dilakukan modifikasi layering demi pertumbuhan pohon yang optimal.

\section{Kategori Sesuai-Sedang}

Pohon yang termasuk kedalam kategori sesuai dengan tingkat toleransi sedang terdiri dari bungur (Lagerstomia speciousa), kapuk (Ceiba pentandra), 
bisbul (Dyospyros blancoi), dan aren (Arenga piñata). Jenis tanaman pada kategori ini berjumlah $5,01 \%$ dari total populasi yang ada. Jenis tanaman ini diharapkan dipertahankan karena berpotensi dalam menyerap polutan gas.

\section{Kategori Sesuai-Sensitif}

Pohon yang sesuai untuk menyerap polutan berbentuk gas dengan tingkat toleransi sensitif terdiri dari beringin (Ficus benjamina). Jenis tanaman pada kategori ini berjumlah $0,52 \%$ dari total populasi yang ada. Jenis tanaman ini diharapkan dipertahankan karena memiliki potensi namun diperlukan modifikasi layering demi pertumbuhan yang optimal.

\section{Ǩategori Kurang Sesuai-Sedang}

Pohon yang kurang sesuai untuk menyerap polutan berbentuk gas dengan [ైngkat toleransi sedang terdiri dari angsana (Artocarpus heterophyllus) dan sempur (Dillenia indica). Jenis tanaman pada kategori ini berjumlah 2,9\% dari têtal populasi yang ada. Fungsi jalur hijau jalan untuk menyerap polutan gas dapat disoptimalkan dengan penanaman jarak tanam pohon yang rapat. Selain itu, dapat jüga menambahkan penanaman tanaman semak atau perdu.

\section{Kategori Kurang Sesuai-Sensitif}

Pohon yang kurang sesuai untuk menyerap polytan berbentuk gas dengan tingkat toleransi sensitif terdiri dari cempaka (Michelia champaca) dan damar (Agathis damara), magga (Magnifera indica) dan walisongo (Schefflera grandiflora). Jenis tanaman ini berjumlah $8,7 \%$ dari total populasi yang ada. Eungsi jalur hijau jalan untuk menyerap polutan gas dapat dioptimalkan dengan penanaman jarak tanam pohon yang rapat. Selain itu, dapat juga menambahkan penanaman tanaman semak atau perdu serta dengan komposisi multilayer.

\section{Kategori Tidak Sesuai-Sedang}

Pohon yang tidak sesuai untuk menyerap polytan berbentuk gas dengan tingkat toleransi sensitif terdiri dari palem putri (Veitchia merilii). Jenis tanaman ini berjumlah $1,58 \%$ dari total populasi yang ada. Kategori ini tidak memenuhi sebagian besar kriteria untuk menyerap polutan gas. Namun pemanfaatan jenis pohon kategori ini untuk fungsi menyerap polutan gas dapat dilakukan dengan penambahan pohon, perdu, atau semak. Jenis yang dipilih yaitu jenis yang memiliki ketahanan tinggi terhadap polusi udara dan juga bermassa daun padat. Penanaman dilakukan pada jarak tanam yang rapat.

\section{Kategori Tidak Sesuai-Sensitif}

Pohon yang tidak sesuai untuk menyerap polutan berbentuk gas dengan tingkat toleransi sensitif terdiri dari palem phoenix (Phoenix robelinii). Jenis tanaman ini berjumlah $0,52 \%$ dari total populasi yang ada. Kategori ini tidak memenuhi sebagian besar kriteria untuk menyerap polutan gas. Namun pemanfaatan jenis pohon kategori ini untuk fungsi menyerap polutan gas dapat dilakukan dengan penambahan pohon, perdu, atau semak. Jenis yang dipilih yaitu 
jenis yang memiliki ketahanan tinggi terhadap polusi udara dan juga bermassa daun padat. Penanaman dilakukan pada jarak tanam yang rapat.

Berdasarkan pada hasil penilaian keseuaian fisik sebagai penjerap polusi partikel serta tingkat toleransi terhadap polusi udara, maka jenis pohon terbagi ke dalam lima kategori. Kategori tersebut terdiri dari sangat sesuai-sedang, sangat sesuai-sensitif, sesuai-sedang, sesuai-sensitif, kurang sesuai-sedang, kurang sesuai-sensitif, dan tidak sensuai sedang. Data disajikan pada Tabel 18.

Tabel18. Hubungan fungsi fisik Pohon sebagai penjerap partikel dengan toleransi terhadap polusi udara

$\begin{array}{ccc}\text { Nama tatin } & \begin{array}{c}\text { Pohon sebagai Penjerap } \\ \text { Partikel }\end{array} & \text { APTI }\end{array}$

\section{Diosp Yros blancoi}

Lagerstomia speciosa

Cupresus papuana

Switenia macrophylla

Pterocarpus indicus

Schefftera grandiflora

Magnifera indica

Bauhiñia purpurea

Canarium comunne

Dillenia indica

Miche Tia champaca

Phoenix roebelinii

Mimusop elengi

Artocarpus heterophylus

Terminalia mantaly

Ceiba pentadra

Delonix regia

Agathis damara

Ficus benjamina

Arenga pinata

Veitchia merilii

Roystonea regia

Sangat sesuai
Sangat sesuai
Sangat sesuai
Sesuai
Sesuai
Sesuai
Sesuai
Sesuai
Sesuai
Sesuai
Sesuai
Sesuai
Sesuai
Sesuai
Sesuai
Sesuai
Sesuai
Kurang sesuai
Kurang sesuai
Kurang sesuai
Tidak sesuai
Tidak sesuai

Sedang

Sedang

Sensitif

Sedang

Sensitif

Sensitif

Sensitif

Sensitif

Sensitif

Sedang

Sensitif

Sensitif

Sedang

Sedang

Sensitif

Sedang

Sedang

Sensitif

Sensitif

Sedang

Sedang

\section{Kategori Sangat Sesuai- Sedang}

Pohon yang termasuk kedalam kategori sangat sesuai dengan tingkat toleransi sedang terdiri dari bisbul (Dyospyros blancoi), dan bungur (Lagerstomia speciousa). Jenis tanaman pada kategori ini berjumlah 1,58\% dari total populasi yang(ada. Jenis tanaman ini diharapkan dipertahankan dan ditingkatkan jumlahnya karenamemiliki potensi yang baik dalam menjerap polutan partikel serta tingkat toleransi yang sedang.

\section{Kategori Sangat Sesuai-Sensitif}

Pohon yang sangat sesuai untuk menjerap polutan dengan tingkat toleransi sensitif-terdiri dari cemara gembel (Cupressus papuana). Jenis tanaman pada 
kategori ini berjumlah 2,63\% dari total populasi yang ada. Jenis tanaman tanaman ini diharapkan dipertahankan dan ditingkatkan jumlahnya arena memiliki potensi yang baik dalam menjerap polutan partikel namun diperlukan modifikasi layering demi pertumbuhan yang optimal.

\section{Kategori Sesuai-Sedang}

Pohon yang sesuai untuk menjerap polutan dengan tingkat toleransi sedang hanya terdiri dari sempur (Dillenia indica), mahoni (Switenia macrophylla), kapuk (Ceiba petandra), tanjung (Mimusop elengi), nangka (Artocarpus heterophyllus), mangga (Magnifera indica) dan flamboyan (Delonix regia). Jenis tanaman ini berjumlah $56,46 \%$ dari total populasi yang ada. Jenis tanaman ini diharapkan dipertahankan karena berpotensi dalam menjerap polusi partikel serta memiliki tolernasi yang sedang.

\section{Kategori Sesuai-Sensitif}

Pohon yang sesuai untuk menjerap polutan dengan tingkat toleransi sensitif terdiri dari angsana (Pterocarpus indicus), bunga kupu-kupu (Bauhinia purpurea), kenari (Canarium commune), cempaka (Michelia champaca), palem phoenix (Phoenix roebelinii), ketapang kencana (Terminalia mantaly), dan wैalisongo (Schefflera grandiflora). Jenis tanaman ini berjumlah $26,91 \%$ dari total populasi yang ada. Jenis tanaman ini diharapkan dipertahankan karena berpotensi dalam menjerap polusi partikel namun dalam penaanamanya perlu dilakukan multilayering untuk mengoptimalkan pertumbuhan tanaman tersebut.

\section{Kategori Kurang Sesuai-Sedang}

Pohon yang kurang sesuai untuk menjerap polutan dengan tingkat toleransi sedang terdiri dari aren (Arenga piñata). Jenis tanaman ini berjumlah 2,63\% dari total populasi yang ada. Fungsi jalur hijau jalan untuk menjerap polutan partikel dapat dioptimalkan dengan penanaman jarak tanam pohon yang rapat. Selain itu, dapat juga menambahkan penanaman tanaman semak atau perdu.

\section{Kategori Kurang Sesuai-Sensitif}

Pohon yang kurang sesuai untuk menjerap polutan dengan tingkat toleransi sensitif terdiri dari damar (Agathis damara) dan beringin (Ficus benjamina). Jenis tanaman ini berjumlah $6,06 \%$ dari total populasi yang ada. Eungsi jalur hijau jalan untuk menjerap polutan partikel dapat dioptimalkan Cengan penanaman jarak tanam pohon yang rapat. Selain itu, dapat juga menambahkan penanaman tanaman semak atau perdu serta dengan komposisi multilayer.

\section{Kategori Tidak Sesuai-Sedang}

Pohon yang tidak sesuai untuk menjerap polutan dengan tingkat toleransi sedang terdiri dari putri (Veitchia merilii). Kategori ini tidak memenuhi sebagian besar kriteria untuk menjerap polutan partikel. Jenis tanaman ini berjumlah 1,58\% dari total populasi yang ada. Namun pemanfaatan jenis pohon kategori ini untuk fungsi menjerap polutan partikel dapat dilakukan dengan penambahan pohon, 
perdu, atau semak. Jenis yang dipilih yaitu jenis yang memiliki ketahanan tinggi terhadap polusi udara dan juga bermassa daun padat. Penanaman dilakukan pada jarak tanam yang rapat.

\section{Hubungan Evaluasi Fungsi Fisik dengan Toleransi terhadap Polusi Udara}

Untuk mengetahui kesimpulan pada setiap aspek evaluasi maka dilaukan pembobotan pada setiap aspek. Pada setiap aspek evaluasi terdapat empat kategori yaitu sangat sesuai, sesuai, kurang sesuai dan tidak sesuai. Pembobotan nilai ini berfungsi untuk membandingkan total nilai yang diperoleh dengan total nilai ideal lalu menghitungknya menjadi persentase untuk dikategorikan lagi menjadi 4 kategofi final untuk mengetahui kesesuaian pohon terhadap polusi udara. Hubungan evaluasi ditampilkan pada tabel 19 dibawah ini

Tabel 19 . Hubungan setiap aspek evaluasi pohon terhadap polusi udara

\begin{tabular}{|c|c|c|c|c|c|c|}
\hline Namâspesies & $\mathrm{K} 1$ & $\mathrm{~K} 2$ & $\mathrm{~T}$ & $\begin{array}{l}\text { Total } \\
\text { Nilai }\end{array}$ & $\begin{array}{c}\text { Persentase } \\
(\%)\end{array}$ & Keterangan \\
\hline Delonix regia & 4 & 3 & 2 & 9 & 75 & Sesuai \\
\hline Mimusoph elengi & 4 & 3 & 2 & 9 & 75 & Sesuai \\
\hline Switeñia mahogany & 4 & 3 & 2 & 9 & 75 & Sesuai \\
\hline cupressis papuana & 4 & 4 & 1 & 9 & 75 & Sesuai \\
\hline Lagenstomia speciousa & 3 & 4 & 2 & 9 & 75 & Sesuai \\
\hline Diyospiriros blancoi & 3 & 4 & 2 & 9 & 75 & Sesuai \\
\hline Canarium comune & 4 & 3 & 1 & 8 & 66.67 & Sesuai \\
\hline Pteroearpus indicus & 4 & 3 & 1 & 8 & 66.67 & Sesuai \\
\hline Terminalia mantaly & 4 & 3 & 1 & 8 & 66.67 & Sesuai \\
\hline Bauhinia purpurea & 3 & 4 & 1 & 8 & 66.67 & Sesuai \\
\hline Ceiba petandra & 3 & 3 & 2 & 8 & 66.67 & Sesuai \\
\hline $\begin{array}{l}\text { Artocarpus } \\
\text { heterophillus }\end{array}$ & 2 & 3 & 2 & 7 & 58.33 & Sesuai \\
\hline Dillenia indica & 2 & 3 & 2 & 7 & 58.33 & Sesuai \\
\hline Ficus benjamina & 3 & 2 & 1 & 6 & 50 & Kurang sesuai \\
\hline Arenga pinata & 2 & 2 & 2 & 6 & 50 & Kurang sesuai \\
\hline Magnifera indica & 2 & 3 & 1 & 6 & 50 & Kurang sesuai \\
\hline Michelia champaca & 2 & 3 & 1 & 6 & 50 & Kurang sesuai \\
\hline Schefflera grandiflora & 2 & 3 & 1 & 6 & 50 & Kurang sesuai \\
\hline Agathis damara & 2 & 2 & 1 & 5 & 41.67 & Kurang sesuai \\
\hline Phoenix roebelinii & 1 & 3 & 1 & 5 & 41.67 & Kurang sesuai \\
\hline Veitchia merilii & 1 & 1 & 2 & 4 & 33.33 & Kurang sesuai \\
\hline Roystonea regia & 2 & 1 & & 3 & 25 & Tidak sesuai \\
\hline
\end{tabular}

Keterangan : $\mathrm{K} 1=$ Evaluasi fungsi fisik pohon terhadap polusi gas, $\mathrm{K} 2=$ Evaluasi fisik pohon terhadap polusi partikel, $\mathrm{T}=\mathrm{APTI}$

Pohon yang terdapat pada jalur hijau Lingkar Luar Kebun Raya terdiri dari 3 kategori kesesuaian yaitu sesuai, kurang sesuai dan tidak sesuai. Tidak ada kategori sangat sesuai karena pada aspek APTI tidak terdapat jenis pohon yang mendapatkan nilai 4 atau 3 karena hanya terdapat dua kategori terbawah yaitu 
sedang dan cukup. Jenis pohon didominasi oleh kategori seusai sebanyak $83,38 \%$ dari total populasi, kategori kurang sesuai sebanyak $14,51 \%$ dari total populasi, dan kategori tidak sesuai sebanyak $2,11 \%$ dari total populasi. Hal ini membuktikan bahwa pohon di jalur luar Lingkar Kebun Raya masih didominasi oleh jenis pohon yang sesuai. Diharapkan keadaan pohon yang ada dapat dipertahankan karena masih memenuhi evaluasi.

\section{Rekomendasi}

Berdasarkan hasil penelitian, tidak ada spesies pohon yang toleran dengan polusi udara sehingga rekomendasi ini terdiri dari penelitian sebelumnya dengan 丽etode yang sama namun dengan objek penelitian yang berbeda. Penelitian Sébelumnya dilakukan Udayana (2004) dan Dwiputri (2014). Kedua penelitian tersebut membahas tentang toleransi tanaman di daerah berpolusi dengan menggunakan metode APTI. Udayana (2004) melakukan penelitian dengan objek pohon di tepi jalan tol sementara Dwiputri (2015) dengan objek berupa pohon di ârea industri.

Udayana (2004) memiliki hasil sampling udara yang menunjukan konsentari $\mathrm{SO} 2, \mathrm{CO}, \mathrm{Pb}, \mathrm{H}_{2} \mathrm{~S}$, dan $\mathrm{NO}_{2}$ di ruas jalan tol lebih rendah dari nilai baku mutu yang diperkenankan oleh ambien. Namun konsentrasi $\mathrm{NO}_{2}, \mathrm{HC}$, dan Debu TSP di lokasi penelitian telah melebihi baku mutu. Hasil penelitian menunjukan ada dua spesies pohon toleran terdiri dari kihujan (Samanea saman), dan dadap merah (Erythryna crystagaly) dengan nilai APTI yang tertera pada täbel 16. Pada Penelitian Dwiputri (2015), metode yang digunakan untuk mengukur toleransi suatu tanaman terdiri dari dua metode yang berbeda yaitu APTi dan relative growth index. Dalam penelitian ini hasil yang digunakan untuk rekomendasi adalah hanya yang menggunakan metode APTI. Dalam penelitian Dwiputri (2015), terdapat lima spesies toleran yaitu waru (Hibiscus tilaceus), lamtoro (Leucana leucophyla), angsnaa (Pterocarpus indicus), akasia daun kecil (Acacia auriculiformis) dan mahony (Switenia mahogany). Terdapat perbedaan nilai APTI dengan penelitian ini pada spesies pohon mahony dan angsana. Nilai APTI pada penelitian Dwiputri terukur lebih besar disbanding pada penelitian ini. Hal ini bisa diakibatkan karena kondisi ambien udara yang berbeda. Penelitian ini area yang diamati adalah area industri dengan zat yang terukur masih dibawah baku mutu. Konsentrasi zat yang masih dalam kategori aman dapat menjadi penyebab perbedaan hasil pengukuran APTI yang berbeda. Rekomendasi jenis pohon yang toleran pada pencemaran udara untuk meningkatkan efektifitas penyerapan polusi udara berjumlah 6 spesies pohon. Jenis pohon dengan deskripsi yang direkomendasikan tersaji dalam Tabel 20 berikut ini.

Tabel 20. Rekomendasi tanaman toleran polusi udara

\begin{tabular}{|c|c|c|}
\hline No & Nama Latin & Identifikasi \\
\hline 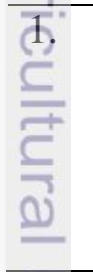 & $\begin{array}{l}\text { Erythrina crista-gally } \\
\text { Nama lokal: dadap } \\
\text { merah }\end{array}$ & $\begin{array}{l}\text { Dadap merah adalah pohon anggota suku Fabaceae. } \\
\text { Pohon yang berukuran sedang, mencapai tinggi } 15-20 \mathrm{~m} \text {. } \\
\text { Bagian kulit batang yang masih muda dan halus bergaris- } \\
\text { garis vertikal hijau, abu-abu, coklat muda atau keputihan; } \\
\text { batang biasanya dengan duri-duri tempel kecil (1-2mm) } \\
\text { yang berwarna hitam. Tajuknya serupa payung atau }\end{array}$ \\
\hline
\end{tabular}




\begin{tabular}{|c|c|c|}
\hline & & $\begin{array}{l}\text { membulat renggang, menggugurkan daun di musim } \\
\text { kemarau. Daun majemuk beranak daun tiga, hijau hingga } \\
\text { hijau muda, poros daun dengan tangkai panjang } 10-40 \mathrm{~cm} \text {. } \\
\text { Menurut penelitian yang dilakukan oleh Udayana }(2004) \text {, } \\
\text { pohon ini termasuk tingkat toleransi toleran dengan nial } \\
\text { APTI 21. Selain toleransi terhadap polusi udara yang } \\
\text { tinggi, pohon ini memiliki bunga yang semarak sehingga } \\
\text { dapat menguatkan karakter suatu jalan. }\end{array}$ \\
\hline 2. & 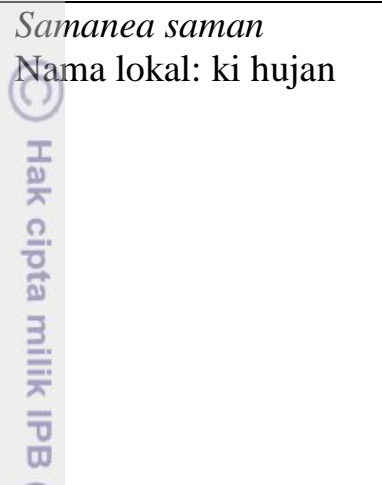 & $\begin{array}{l}\text { Pohon ki hujan dapat mencapai ketinggian rata-rata } 30- \\
40 \mathrm{~m} \text {, lingkar pohon sekitar } 4,5 \mathrm{~m} \text { dan kanopi mencapai } \\
40-60 \mathrm{~m} \text {. Bentuk batangnya tidak beraturan kadang } \\
\text { bengkok, menggelembung besar. Daunnya majemuk } \\
\text { mempunyai panjang tangkai sekitar } 7-15 \mathrm{~cm} \text {. Sedangkan } \\
\text { pada pohon yang sudah tua berwarna kecokelatan dan } \\
\text { permukaan kulit sangat kasar dan sukar terkelupas. } \\
\text { Menurut penelitian yang dilakukan oleh Udayana (2004), } \\
\text { pohon ini termasuk keladalam tingkat toleransi toleran } \\
\text { dengan nilai APTI } 21 \text {. Pohon ini kerap digunakan sebagai } \\
\text { pohon peneduh karena tajuknya yang luas. }\end{array}$ \\
\hline 3. & 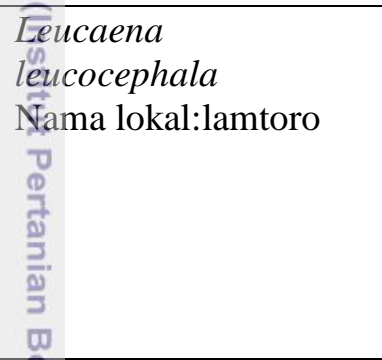 & $\begin{array}{l}\text { Pohon lamtoro memiliki tinggi hingga } 20 \mathrm{~m} \text { walau rata- } \\
\text { rata hanya sekitar } 2-10 \mathrm{~m} \text {. Percabangannya rendah dan } \\
\text { banyak, dengan batang berwarna kecoklatan atau keabu- } \\
\text { abuan, berbintil-bintil dan berlentisel. Menurut penelitian } \\
\text { yang dilakukan Dwiputri (2015), pohon ini termasuk } \\
\text { kedalam tingkat toleransi toleran dengan nilai APTI } \\
\text { 24.63. Pohon ini biasa digunakan sebagai pohon peneduh } \\
\text { dan buahnya dapat dimanfatkan sebagai bahan makanan. }\end{array}$ \\
\hline 4. & $\begin{array}{l}\text { Acacia auriculiformis } \\
\text { Nama lokal: akasia } \\
\text { daun kecil }\end{array}$ & $\begin{array}{l}\text { Pohon akasia adalah pohon evergreen dengan tinggi 15- } \\
20 \mathrm{~m} \text {. Pohon ini memiliki perakaran yang dangkal dan } \\
\text { menyebar sehingga kurang cocok untuk pohon tepi jalan } \\
\text { karena dapat tumbang sewaktu-waktu serta merusak } \\
\text { perkerasan. Pohon ini cocok untuk greenbelt suatu } \\
\text { kawasan industri atau kawasan urban. Pohon jenis ini } \\
\text { memiliki tingkat toleransi cukup toleran menurut Udayana } \\
\text { (2004) dan Dwiputri (2015) }\end{array}$ \\
\hline 5. & $\begin{array}{l}\text { Cerbera maghas } \\
\text { Nama lokal: bintaro }\end{array}$ & $\begin{array}{l}\text { Pohon bintaro memeiliki habitus yang luas dari daerah } \\
\text { pantai hingga pegunungan rendah dengn iklim tropis. } \\
\text { Pohon ini dapat tumbuh sampai ketinggian } 12 \mathrm{~m} \text {. Daunnya } \\
\text { berbentuk bulat telur, berwarna hijau tua, yang tersusun } \\
\text { berselingan. Bunganya harum dengan mahkota } \\
\text { berdiameter } 3-5 \mathrm{~cm} \text { berbentuk terompet dengan pangkal } \\
\text { merah muda. Menurut penilitian yang dilakukan Udayana } \\
\text { (2004) pohon ini termasuk tingakt toleransi cukup toleran } \\
\text { dengan nilai APTI 18. Pohon ini kerap digunakan sebagai } \\
\text { pohon tepi jalan karena tampilan daun yang semarak. }\end{array}$ \\
\hline 6. & $\begin{array}{l}\text { Hibiscus tilaceus } \\
\text { Nama lokal: waru } \\
\frac{E}{E} \\
\text { ఏ) }\end{array}$ & $\begin{array}{l}\text { Pohon waru merupakan pohon yang tumbuh di daerah } \\
\text { pantai. Pohon ini memiliki tinggi } 5-15 \mathrm{~m} \text {. Pohon ini } \\
\text { memiliki tajuk yang kecil dengan daun yang berbulu serta } \\
\text { tajuk yang renggang. Menurut Dwiputri (2015), pohon ini } \\
\text { termasuk kedalam tingkat toleransi cukup toleran dengan } \\
\text { nilai APTI } 19.16 \text {. Pohon ini memiliki bunga berwarna } \\
\text { kuning, cocok sebagai penyemarak dalam jalur hijau. }\end{array}$ \\
\hline
\end{tabular}




\section{SIMPULAN DAN SARAN}

\section{Simpulan}

berikut :

Berdasarkan hasil studi maka didapatkan beberapa simpulan seperti

1. Kondisi ambien di sekitar Lingkar Luar Kota Bogor bersifat fluktuatif yang terukur selama tiga tahun. Peningkatan terjadi pada debu, $\mathrm{NO}_{2}, \mathrm{H}_{2} \mathrm{~S}, \mathrm{O}_{3}, \mathrm{SO}_{2}$, $\mathrm{Pb}, \mathrm{NH}_{3}$ sedanggkan penurunan terjadi pada $\mathrm{HC}$. Zat yang jumlahnya sudah diatas baku mutu adalah $\mathrm{Pb}$ dan $\mathrm{H}_{2} \mathrm{~S}$ untuk tahun 2018 .

Hasil evaluasi fungsi fisik pohon yang sangat sesuai sebagai penyerap polusi gas berjumlah delapan spesies yang terdiri dari kenari (Canarium commune), flamboyan (Delonix regia), angsana (Pterocarpus indicus), ketapang kencana (Terminalia mantaly), Tanjung (Mimusop elengi), bunga kupu-kupu (Bauhinia purpurea), dan cemara gembel (Cupressus papuana). Pohon yang sangat sesuai sebagai penyerap polusi gas berjumlah $75,46 \%$ dari total populasi. Hasil evaluasi fungsi fisik pohon yang sangat sesuai sebagai penjerap polusi partikel berjumlah tiga spesies yaitu bisbul (Dyaspyros blancoi), bungur (Lagerstomia speciousa), dan cemara gembel (Cupressus papuana). Pohon yang sangat sesuai sebagai penjerap polusi partikel berjumlah $4,22 \%$ dari total populasi.

Tingkat toleransi tanaman terdiri dari tingkat sedang dan sensitif. Pohon dengan tingkat toleransi sedang hanya terdiri dari kapuk (Ceiba petandra) dengan persentase $0,8 \%$ dari total populasi. Pohon dengan tingkat toleransi sensitif terdiri dari damar (Agathis damara), aren (Arenga piñata), nangka (Artocarpus heterophilus), bunga kupu-kupu (Bauhinia purpurea), kenari (Canarium commune), cemara gembel (Cupressus papuana), flamboyan (Delonix regia), sempur (Dillenia indica), bisbul (Dyospyros blancoi), beringin (Ficus benjamina), bungur (Lagerstomia speciousa), manga (Magnifera indica), cempaka (Michelia champaca), tanjung (Mimusoph elengi), palem phoenix (Phoenix roebelini), angsana (Pterocarpus indicus), palem raja (Roystonea regia), walisongo (Schefflera grandiflora), mahoni (Switenia macrophylla), ketapang kencana (Terminalia mantaly), dan palem putri (Veitchia merilii) dengan persentase $99,02 \%$ dari total populasi

4. Rekomendasi tanaman dengan fungsi penyerap polusi gas antara lain adalah kenari (Canarium commune), flamboyan (Delonix regia), angsana (Pterocarpus indicus), ketapang kencana (Terminalia mantaly), Tanjung (Mimusop elengi), bunga kupu-kupu (Bauhinia purpurea), dan cemara gembel (Cupressus papuana). Rekomendasi tanaman dengan fungsi penjerap partikel antara lain adalah bisbul (Dyaspyros blancoi), bungur (Lagerstomia speciousa), dan cemara gembel (Cupressus papuana). Rekomendasi tanaman dengan tingkat toleransi sedang antara lain kapuk (Ceiba petandra), palem putri (Vietchia merilii), tanjung (Mimusoph elengi), bungur (Lagerstomia speciousa), mahoni (Switenia macrophylla), flamboyan (Delonix regia), nangka (Artocarpus heterophyllus), sempur (Dillenia indica), bisbul (Diospyros blancoi), dan aren (Arenga piñata). Rekomendasi tanaman toleran polusi yang bersumber dari penelitian sebelumnya antara lain dadap merah (Erythrina crista-galli), ki hujan (Samanea saman), bintaro (Cerbera 
manghas), waru (Hibiscus tillaceus), akasia (Acacia auriculiformis), dan lamtoro (Leucaena leucocephala)

\section{Saran}

Penelitian selanjutnya disarankan membandingkan nilai APTI antara tanaman yang tumbuh di daerah berpolusi dengan tanaman yang tumbuh di area kontrol guna mendapatkan nilai APTI yang lebih valid. Pengukuran sampling udara disarankan diambil pada setiap kali pengamatan terhadap tanaman sehingga kualitas udara saat pengamatan dapat diketahui sebagai perbandingan dan faktor utama yang mempengaruhi kondisi tanaman.

$$
\text { IT }
$$

Disarankan untuk mengkaji kembali kerusakan yang terjadi pada tanaman di areâ penelitian untuk mengetahui renspons morfologi tanaman terhadap polusi udara. 고 


\section{DAFTAR PUSTAKA}

[BPLH] Badan Pengelola Lingkungan Hidup. 2015. Pengertian Pencemaran Udara. Jakarta (ID): Pemerintah Kota Jakarta

[BPS] Badan Pusat Statistik Kota Bogor. 2018. Kota Bogor Dalam Angka. Bogor (ID): Pemerintah Kota Bogor.

[DBMSA] Dinas Bina Marga dan Sumberdaya Air. 2016. As Built Drawing: Pembangunan Fasilitas Pedestrian dan Jalur Sepeda Seputar Kebun Raya Bogor. Bogor (ID): Pemerintah Kota Bogor.

昂LH] Dinas Lingkungan Hidup. 2018. Hasil Pengujian Ambien Kota Bogor. Kota Bogor (ID): Pemerintah Kota Bogor

[DLLAJ] Dinas Lalu Lintas dan Angkatan Jalan Kota Bogor. 2015. Rekapitulasi Data Lalu Lintas Kota Bogor. Bogor (ID): Pemerintah Kota Bogor.

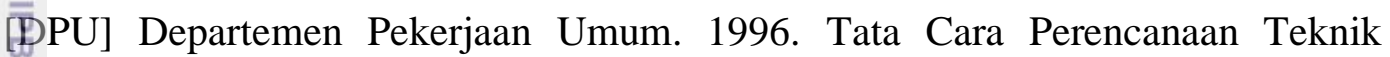
Lansekap Jalan. Jakarta (ID): Direktorat Jenderal Bina Marga.

Agbaire P.O., E. Esiefarienrhe, 2009. Air Pollution Tolerance Index (APTI) of some plants around Otorogun Gas Plant in Delta State, Nigeria. J. Appl. Sci. Environ. Manage. Vol. 13(1) $11-14$.

Ärifin N. 1993. Kontribusi Gerakan Sejuta Pohon terhadap Distribusi Ruang Terbuka Hijau Kota di DKI Jakarta. Forum Komunikasi Lingkungan DKI Jakarta. Jakarta: Biro BLH DKI Jakarta.

Booth, N.K. 1983. Basic Elements of Landscape Architectural Design. Waveland Illinois (US): Waveland Press.

Carpenter, PL, TD Walker, FO Lanphear. 1975. Plants in the Landscape. San Fransisco : W.H.Freeman and Company.

Dahlan, E N. 1992. Hutan Kota untuk Pengelolaan dan Peningkatan Kualitas Lingkungan. Jakarta (ID) : APHI.

Dahlan, EN. 1989. Studi kemampuan tanaman dalam menjerap dan menyerap timbal emisi dari kendaraan bermotor [Tesis]. Fakultas Pascasarjana Institut Pertanian Bogor. IPB. Bogor (ID)

Depkes RI. 2012. Profil Kesehatan Republik Indonesia Tahun 2012.(Online). Diakses di: http://www.depkes.go.id.

Đoujaiji, Bassam dan Jaffar A. Al -Tawfiq. 2010. Hydrogen sulfide exposure in an adult male. Ann Saudi Med. Jan-Feb; 30 (1): 76 - 80.

Dwiputri D. A. 2015. Toleransi spesies pohon terhadap pencemaran udara di kawasan industry Krakatau Kota Cirebon. [Tesis]. Sekolah Pascasarjana: IPB. Bogor (ID).

E. L. Singsaas, D. Thomas, C. J. Sharkey, D. Bernacchi. 2003. Fitting Photosynthetic carbon dioxide response curves for C3 leaves. Plant, Cell and Environment 30: 1035-1040 
Fakuara, Y. 1986. Hutan Kota: Peranan dan Permasalahannya. Departeman Manajemen Hutan. Fakultas Kehutanan, IPB. Bogor.

Fakultas Kehutan IPB . 1987. Fungsi dan Peranan Jalur Hijau Jalan. Fakultas Kehutanan, IPB Bogor. Bogor.

Garsed R. G. dan Rutter A. J. 1982. Relative performance of conifer populations in various tests for senstivity to $\mathrm{SO}_{2}$, and the implications for selecting trees for planting in polluted areas. New Phytol 92: 349-367.

Garsed, S.G. and Rutter, A.J. (1982). Relative performance of conifer populations in yarious tests for sensitivity to SOs, and the implications for selecting trees for planting in polluted areas. New Phytologist 92, 349-367. Hill

Grey G̈W and Deneke FJ. 1978. Urban Forestry. New York: John Wiley \& Sons, Inc.

Gusnita D . 2012 . Pencemaran logam berat timbal $(\mathrm{Pb})$ di udara dan upaya pēnghapusan bensin bertimbal. Jurnal Berita Dirgantara, 13(3): 95-101.

Harris $\overline{\overline{\bar{y}}} \mathrm{CW}$ dan Dines, NT. 1988. Time-Saver Standards for Landscape Architecture : Design and Construction Data. USA : McGraw Hill Inc.

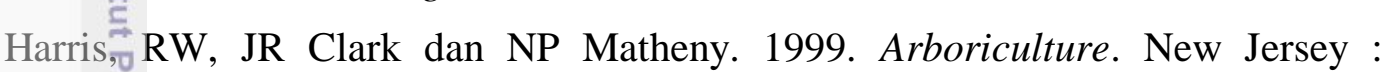
Prentice Hall, Inc.

Hermañwan R, Kusmana C, Nasrullah N, dan Prasetyo LB. 2011. Jerapan Debu đan Partikel Timbal $(\mathrm{Pb})$ oleh Daun Berdasarkan Letak Pohon dan Posisi Eajuk: Studikasus Jalur Hijau Acasia mangium, Jalan TOL Jagorawi. Media Konservasi Vol. 16, No. 3: 101-107.

Hidayat, IW. 2008. Evaluasi jalur hijau jalan sebagai penyangga lingkungan sekitarnya dan keselamatan pengguna jalan bebas hambatan jagorawi [Tesis]. Program Pascasarjana Institut Pertanian Bogor. Tidak dipublikasikan.

Hidayati N. 2009.Mercury and cyanide contaminations in gold mine environment and possible solution of cleaning up by using phytoextraction. Jurnal Biodeversitas 6(1), 31-33

Irianti IC. 2010. Kajian Lanskap Pertigaan Jalan Lingkar Luar Kebun Raya Bogor [Skripsi]. Bogor (ID): Institut Pertanian Bogor Fakultas Pertanian Departemen Arsitektur Lanskap.

Irwan,ZZD. 1997. Tantangan Lingkungan dan Lansekap Hutan Kota. Jakarta; PT Pustaka CIDESINDO.

Kaule, G. 2000. Ecologically Orientated Planning. Frankfurt: Peter Lang.

Klumpp G., Furlan C.M., Domingos M., Klumppa A. 2000. Response of stress indicators and growth parameters of Tibouchina pulchra Cogn. exposed to air and soil pollution near the industrial complex of Cubata ${ }^{\sim}$ o, Brazil. Sci Total Environ 246: 79-91. 
Lestari G., Kencana I.P. 2008. Galeri Tanaman Hias Lanskap. Jakarta (ID): Penebar Swadaya.

Maclachlan S, Zalik S. 1963. Plastid structure, chlorophyll concentration and free amino acid composition of chlorophyll mutant barley. Can J Bot. 1053-1062.

Masuch, G.., Kicinski, H. G., Kettrup A. and Boss, K. S. 1988. Single and combined effects of continuous and discontinuous 03 and $\mathrm{SO}_{2}$ emission on Norway spruce needles. I. Histological and cytological changes. International Journal of Environmental Analytical Chemistry 32, 213-241.

Mudd S. B. and Kozlowski T. T. 1975. Responses of Plants to Air Pollution New York (US): Academic Press.

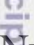

Hugrahani, P. dan Prasetyawati E.T. 2010. Semak Hias Elemen Lanskap Perkotaan sebagai Fitoindikator Pencemaran Udara Sulfur Dioksida dalam Kajian Hormesis. LPPM -UPN "Veteran" Jawa Timur. 1-8.

Nurfaida, Dariati T, Yanti CWB. 2011. Bahan Ajar Ilmu Tanaman Lanskap. Program hibah penulisan buku ajar. Makassar (ID): Universitas Hasanuddin.

Patra, Astra Dwi. 2002. Faktor tanaman dan faktor lingkungan yang mempengaruhi kemampuan tanaman dalam menyerap polutan gas NO2 [Tesis]. Program Pascasarjana Institut Pertanian Bogor.

Pemerintah Republik Indonesia. 2005. Peraturan Pemerintah Republik Indonesia Nomor 15 Tahun 2005 tentang Jalan Tol. Jakarta (ID).

Pemerintah Republik Indonesia. 2008. Peraturan Menteri Pekerjaan Umum Nomor 05 tahun 2008 tentang Pedoman Penyediaan dan Pemanfaaatan Ruang Terbuka Hijau di Kawasan Perkotaan. Jakarta (ID). 34 hal

Peraturan Kementrian Pekerjaan Umum No 5 Tahun 2008 tentang Pedoman Penyediaan Dan Pemanfaatan Ruang Terbuka Hijau Di Kawasan Perkotaan.

PT. Jasa Marga Cabang CTC. 2011. Laporan akhir evaluasi implementasi RKL dan RPL jalan tol Cawang Tomang Cengkareng semester I tahun 2011. Jakarta (ID): PT. Jasa Marga.

Raunkiaer C. 1934. The Life Forms of Plants and Statistical Plant Geography. London (EN): Oxford University Press.

Rai R, et al. 2013. Gln3 mutations dissociate responses to nitrogen limitation (nitrogen catabolite repression) and rapamycin inhibition of TorC1. J Biol Chem 288(4):2789-804

Rosanti D. 2011. Morfologi Tumbuhan. Jakarta (ID): Erlangga

Sastrawijaya, T. 1991. Pencemaran Lingkungan. Jakarta: Bineka Cipta.

Simonds, JO. 1978. Earthscape : A Manual of Environmental Planning. USA :

McGraw Hill Inc. 
Simonds, JO. 1983. Landscape Architecture. New York (US): McGraw-Hill Book Company

Singh S. K. dan Rao D. N.. 1983. Air Polution Tolerance Index of Plants. Journal of Enviromental management 32:45-55

Singh, S.K., D.N. Rao, M.Agrawal, J. Pande, and D.Narayan. 1991. Air pollution toleranceindex ofplants. J. Environ. Manage.32: 45-55.

Soemarno SH. 1999. Catatan Kuliah Meteorologi Pencemaran Udara. Bandung: Penerbit ITB.

Suhanđi R., Arief B., Rahmah A. 2017. Evaluasi Kinerja Jalan pada Penerapan Siștem Satu Arah di Kota Bogor. Program Studi Teknik Sipil Universitas Păkuan: Universitas Pakuan. Bogor (ID)

Taihututu, Hermina Neltje. 2001. Studi kemampuan tanaman jalur hijau jalan sēagai penjerap partikulat hasil emisi kendaraan bermotor [Tesis]. Program Pascasarjana Institut Pertanian Bogor. Tidak dipublikasikan.

Tambầu, E., 2012. Potensi Absorpsi Karbon Dioksida Pada Beberapa Jenis Pohon Hutan Kota di Kota Makassar. Pasca Sarjana Universitas Hasanuddin, Makkassar

Tripathi RD, Srivastava S, Mishra S, Singh N, Tuli R, Gupta DK, Maathuis FHM . 2007 Arsenic hazards: strategies for toleranceand remediation by plänts. Trends Biotechnol 25:158-165

Udayaña C. 2004. Toleransi Spesies Pohon Tepi Jalan terhadap Pencemaran Udara di Simpang Susun Jakarta Interchange. [Tesis]. Sekolah Pascasarjana IPB: IPB. Bogor (ID)

Udayana, C. 2004. Toleransi spesies pohon tepi jalan terhadap pencemaran udara di simpang susun Cawang, Jakarta Timur [Tesis]. Program Pascasarjana Instirut Pertanian Bogor.

Wardhana WA. 2001. Dampak Pencemaran Lingkungan. Edisi revisi. Yogyakarta: Andi

Waryanti, S. Irawan, Dasumiati. 2015. Angsana sebagai Bioindikator untuk Polusi di Sekitar Lebak Bulus. Al Kauniyah Jurnal Biologi Volume 8 No 1. 46-50 


\section{LAMPIRAN}

Lampiran 1. Jenis, letak dan jumlah pohon pada Lingkar Luar Kebun Raya Bogor

\begin{tabular}{|c|c|c|c|c|c|c|}
\hline Nama Latin & $\begin{array}{c}\text { Jl. } \\
\text { Pajajaran }\end{array}$ & J1. Otista & $\begin{array}{c}\text { Jl. } \\
\text { Juanda }\end{array}$ & $\begin{array}{l}\text { Jl. Jalak } \\
\text { Harupat }\end{array}$ & Total & $\begin{array}{c}\text { Persentase } \\
(\%)\end{array}$ \\
\hline Agathis damara & 14 & 6 & - & 1 & 21 & 5.54 \\
\hline Arenga pinata & - & 10 & - & - & 10 & 2.63 \\
\hline Artocarpus heterophillus & 1 & - & 3 & 4 & 8 & 2.11 \\
\hline Bauhinia purpurea & - & 2 & - & - & 2 & 0.52 \\
\hline Canarium comunee & - & 1 & 58 & 1 & 60 & 15.83 \\
\hline Ceiba petandra & 3 & - & - & - & 3 & 0.79 \\
\hline${ }_{\bar{C}}^{\bar{C}}$ upressus papuana & 10 & - & - & - & 10 & 2.63 \\
\hline Delonix regia & 1 & 1 & - & 3 & 5 & 1.31 \\
\hline Dillenia indica & 1 & - & - & - & 1 & 0.26 \\
\hline Dyospyros blancoi & - & 2 & - & - & 2 & 0.52 \\
\hline Ficus benjamina & 1 & - & 1 & - & 2 & 0.52 \\
\hline Lagerstomia speciousa & - & 4 & - & - & 4 & 1.05 \\
\hline Mangifera indica & - & 1 & 1 & - & 2 & 0.52 \\
\hline Michelia champaca & 6 & - & & - & 6 & 1.58 \\
\hline Mimusoph elengi & 38 & 4 & 6 & 23 & 71 & 18.73 \\
\hline Phoenix roebelinii & - & - & 2 & - & 2 & 0.52 \\
\hline Pterocarpus indicus & 1 & 8 & - & 1 & 10 & 2.63 \\
\hline Roystonea regia & - & - & 8 & - & 8 & 2.11 \\
\hline Schefflera grandiflora & - & - & - & 6 & 6 & 1.58 \\
\hline Switenia macrophylla & 80 & - & 10 & 36 & 126 & 33.24 \\
\hline Terminalia mantaly & 10 & 4 & - & - & 14 & 3.69 \\
\hline Vietchia merilii & - & - & 4 & 2 & 6 & 1.58 \\
\hline Total & 166 & 43 & 93 & 77 & 379 & 100 \\
\hline
\end{tabular}

Lampiran 2. Skor Key Performance Index pohon terhadap polusi gas

\begin{tabular}{lcccccl}
\hline Nama Latin & A1 & A2 & A3 & Total & Persentase & Keterangan \\
\hline C. comune & 3 & 4 & 4 & 11 & 91.66 & SS \\
D. regia & 4 & 4 & 3 & 11 & 91.66 & SS \\
D. indicus & 4 & 4 & 3 & 11 & 91.66 & SS \\
C. mantaly & 3 & 4 & 4 & 11 & 91.66 & SS \\
M. elengi & 2 & 4 & 4 & 10 & 83.33 & SS \\
S. macrophylla & 3 & 4 & 3 & 10 & 83.33 & SS \\
C. papuana & 4 & 3 & 3 & 10 & 83.33 & SS \\
B. purpurea & 4 & 3 & 2 & 9 & 75 & $\mathrm{~S}$ \\
F. benjamina & 2 & 4 & 3 & 9 & 75 & $\mathrm{~S}$ \\
D. speciousa & 3 & 3 & 3 & 9 & 75 & $\mathrm{~S}$ \\
C. petandra & 3 & 2 & 3 & 8 & 66.66 & $\mathrm{~S}$ \\
D. blancoi & 1 & 3 & 4 & 8 & 66.66 & $\mathrm{~S}$ \\
A. pinata & 3 & 2 & 2 & 7 & 58.33 & $\mathrm{KS}$
\end{tabular}


Lanjutan Lampiran 2. Skor Key Performance Index pohon terhadap polusi gas

\begin{tabular}{lllllcl}
\hline A. heterophillus & 2 & 2 & 3 & 7 & 58.33 & KS \\
D. indica & 1 & 2 & 4 & 7 & 58.33 & KS \\
M. indica & 2 & 2 & 3 & 7 & 58.33 & KS \\
M. champaca & 2 & 2 & 2 & 6 & 50 & KS \\
A. damara & 1 & 2 & 2 & 5 & 41.66 & KS \\
R. regia & 3 & 1 & 1 & 5 & 41.66 & KS \\
$P$. roebelinii & 2 & 1 & 1 & 4 & 33.33 & TS \\
$V$. merilii & 2 & 1 & 1 & 4 & 33.33 & TS \\
\hline
\end{tabular}

Kriteria : A1= kepadatan tajuk, $\mathrm{A} 2=$ daun tipis, $\mathrm{A} 3=$ jumlah daun banyak Keterangan $: \mathrm{SS}=$ sangat sesuai, $\mathrm{S}=$ sesuai, $\mathrm{KS}=$ kurang sesuai, dan $\mathrm{TS}=$ tidak sesuai․․․

Lampi 3 3. Skor Key Performance Index pohon terhadap polusi partikel

\begin{tabular}{lcccccccl}
\hline Nama latin & B1 & B2 & B3 & B4 & B5 & Total & Persentase & Keterangan \\
\hline D. blañcoi & 4 & 4 & 3 & 3 & 4 & 18 & 90 & SS \\
L. speciousa & 3 & 4 & 4 & 3 & 3 & 17 & 85 & $\mathrm{SS}$ \\
S. mahogany & 2 & 3 & 4 & 4 & 4 & 17 & 85 & $\mathrm{~S}$ \\
C. paptuana & 4 & 3 & 3 & 3 & 3 & 16 & 81.25 & $\mathrm{~S}$ \\
P. indicus & 3 & 3 & 3 & 3 & 4 & 16 & 80 & $\mathrm{~S}$ \\
S. grandiflora & 4 & 4 & 2 & 2 & 3 & 15 & 75 & $\mathrm{~S}$ \\
B. purpurea & 4 & 4 & 2 & 2 & 3 & 15 & 75 & $\mathrm{~S}$ \\
M. indica & 2 & 3 & 3 & 3 & 2 & 13 & 65 & $\mathrm{~S}$ \\
D. indica & 1 & 4 & 3 & 3 & 3 & 14 & 70 & $\mathrm{~S}$ \\
M. elengi & 2 & 2 & 3 & 4 & 3 & 14 & 70 & $\mathrm{~S}$ \\
C. comune & 2 & 3 & 2 & 4 & 3 & 14 & 70 & $\mathrm{~S}$ \\
M. champaca & 2 & 4 & 2 & 2 & 4 & 14 & 70 & $\mathrm{~S}$ \\
P. roebelinii & 3 & 1 & 4 & 1 & 4 & 13 & 65 & $\mathrm{~S}$ \\
A. heterophillus & 1 & 3 & 2 & 3 & 2 & 11 & 55 & $\mathrm{KS}$ \\
T. mantaly & 2 & 1 & 2 & 4 & 3 & 12 & 60 & $\mathrm{KS}$ \\
C. petandra & 2 & 2 & 2 & 2 & 4 & 12 & 60 & $\mathrm{KS}$ \\
D. regia & 3 & 1 & 2 & 2 & 2 & 10 & 50 & $\mathrm{KS}$ \\
A. damara & 1 & 2 & 3 & 2 & 2 & 10 & 50 & $\mathrm{KS}$ \\
A. pinata & 2 & 1 & 4 & 1 & 1 & 9 & 45 & $\mathrm{KS}$ \\
F. benjamina & 1 & 2 & 2 & 3 & 2 & 10 & 50 & $\mathrm{KS}$ \\
V. merilii & 1 & 1 & 2 & 1 & 1 & 6 & 30 & $\mathrm{TS}$ \\
R. regia & 1 & 1 & 2 & 1 & 1 & 6 & 30 & $\mathrm{TS}$
\end{tabular}

Kriteria : B1= struktur permukaan, tepi daun kasar, berlekuk, berbulu/ bertrikoma, B2 = berdaun jarum atau lebar, B3= keadatan tajuk, B4= tekstur kulit batang dan ranting kasar , ranting berduri, $\mathrm{B} 5=$ kepadatan ranting

Keterangan : $\mathrm{SS}=$ sangat sesuai, $\mathrm{S}=$ sesuai, $\mathrm{KS}=$ kurang sesuai, dan $\mathrm{TS}=$ tidak sesuai 
Lampiran 3. Foto kondisi lapangan

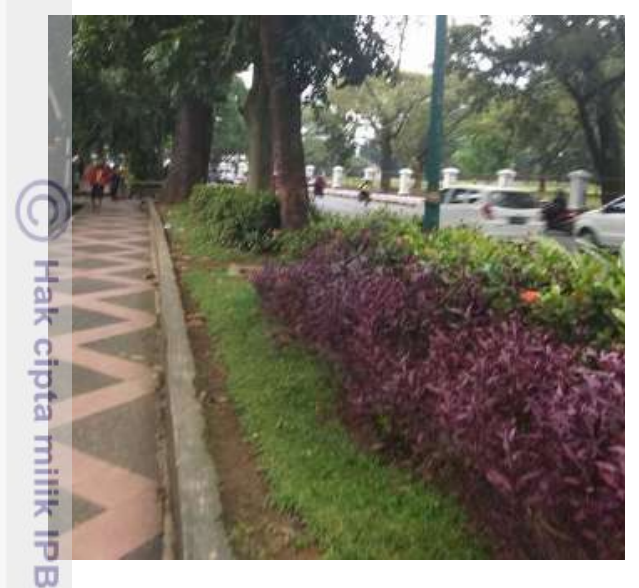

Jalur Hijau di Jl. Juanda

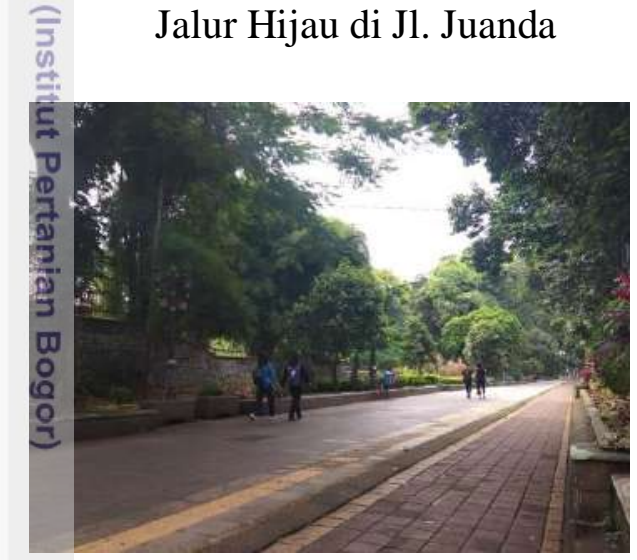

Jalur Hijau di Jl. Pajajaran

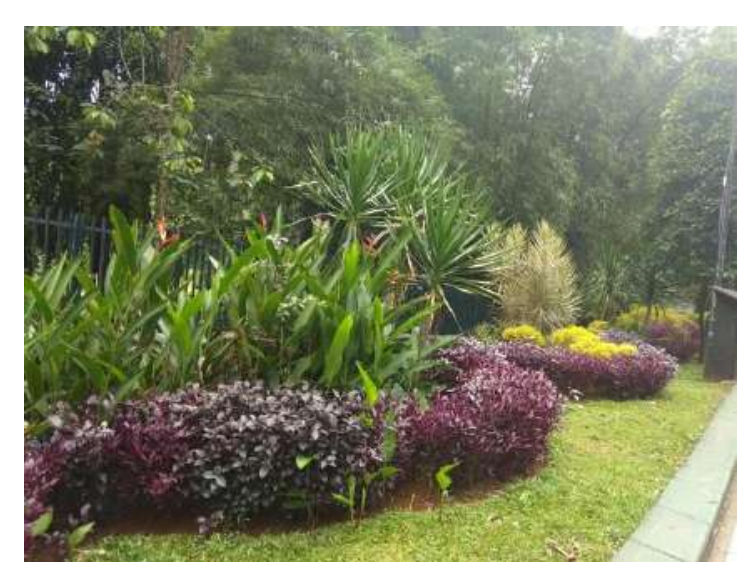

Jalur Hijau di Jl. Jalak Harupat

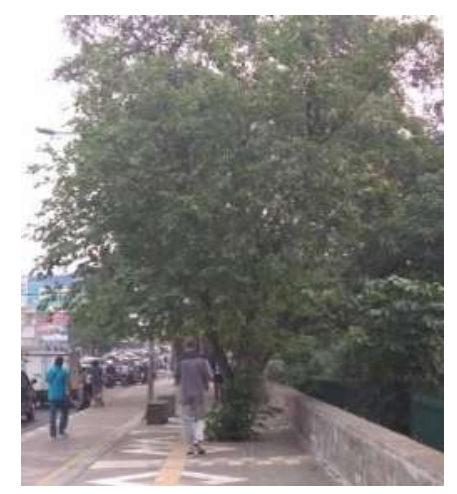

Jalur Hijau di Jl. Otista

Lampiran 4. Proses pengambilan sampel

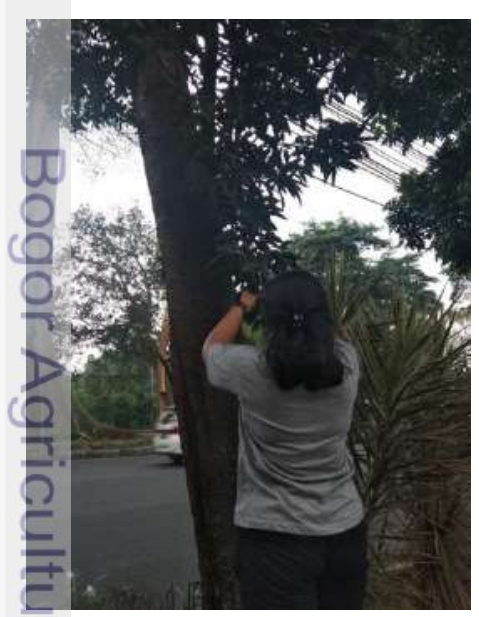

Proses pengambilan sampel

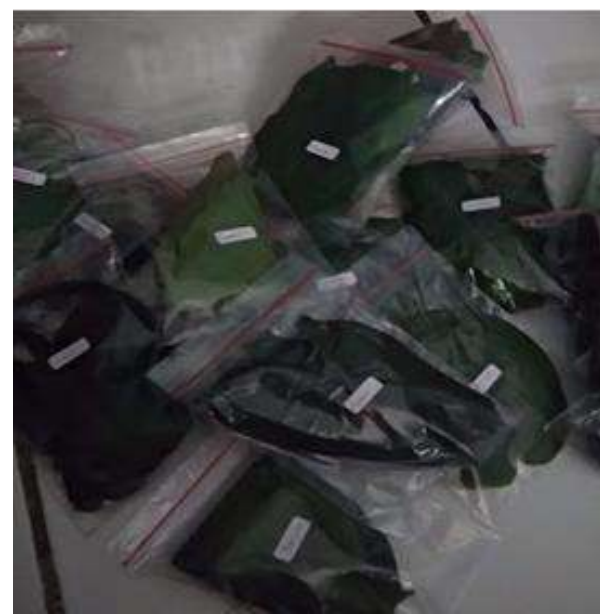

Sampel dibungkus plastik klip 
Lampiran 5. Dokumentasi di Laboratorium

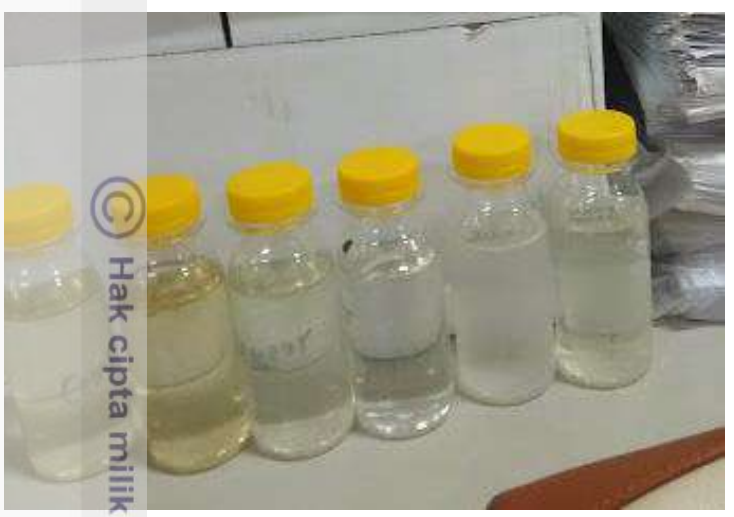

Wasil ekstraksi daun sampel

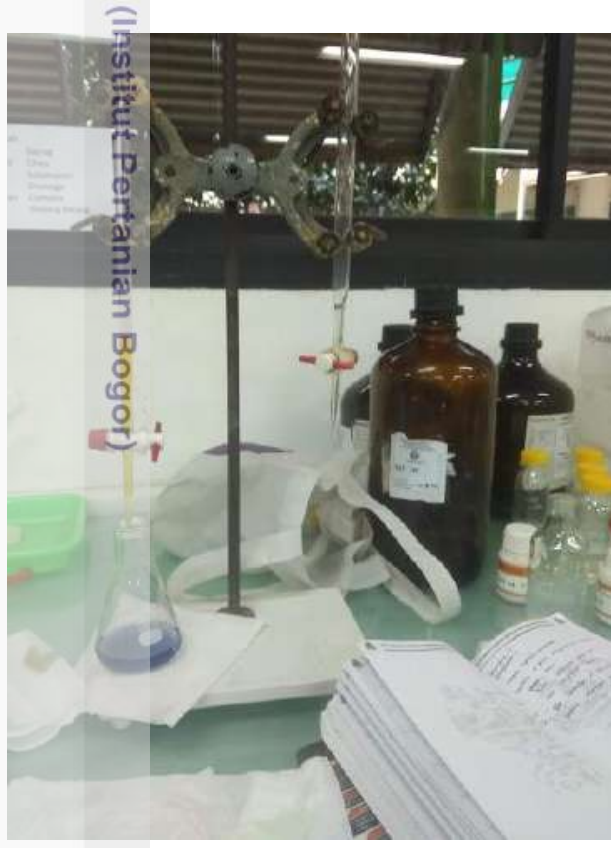

Proses titrasi ekstrak sampel

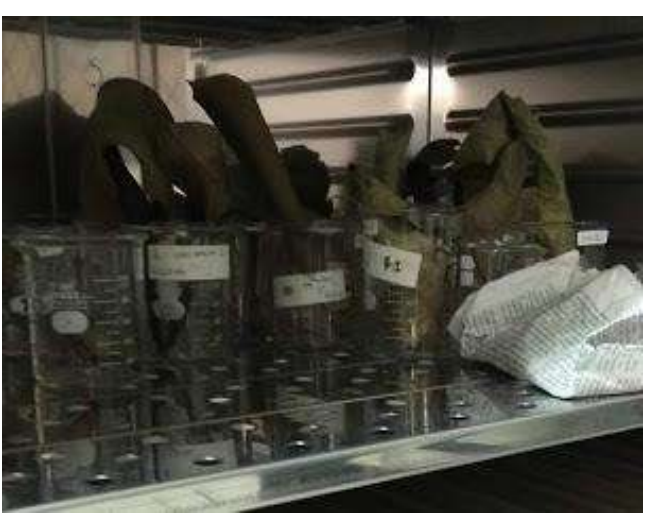

Proses pemanggangan sampel

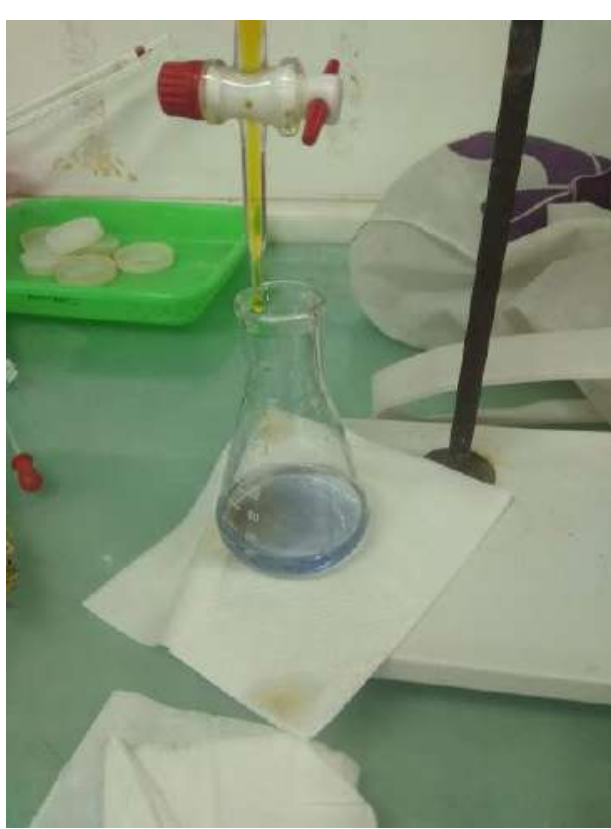

Hasil titrasi ekstrak sampel

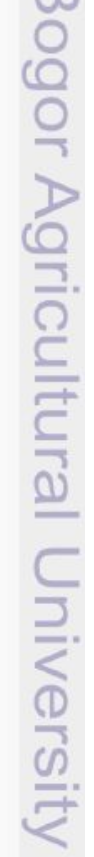


Lampiran 6. Foto sampel daun

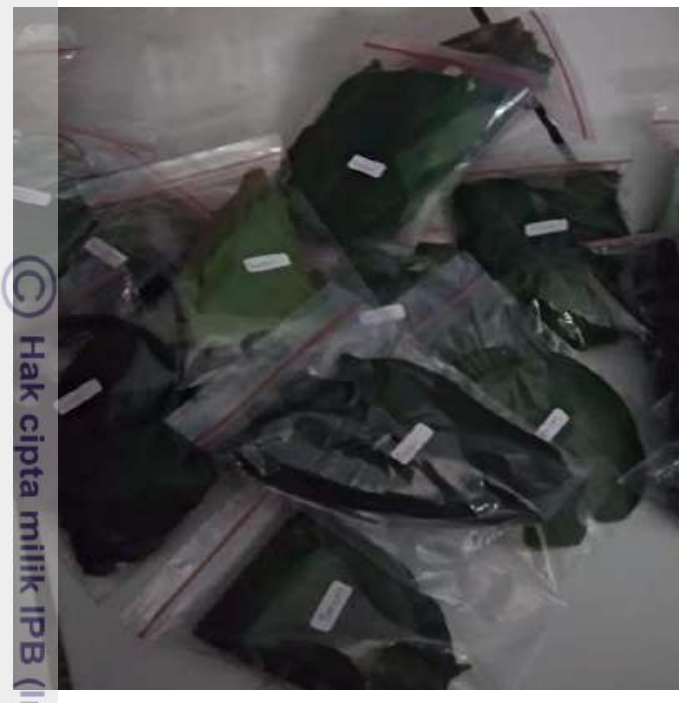

Sampel yang dibungkus klip plastik

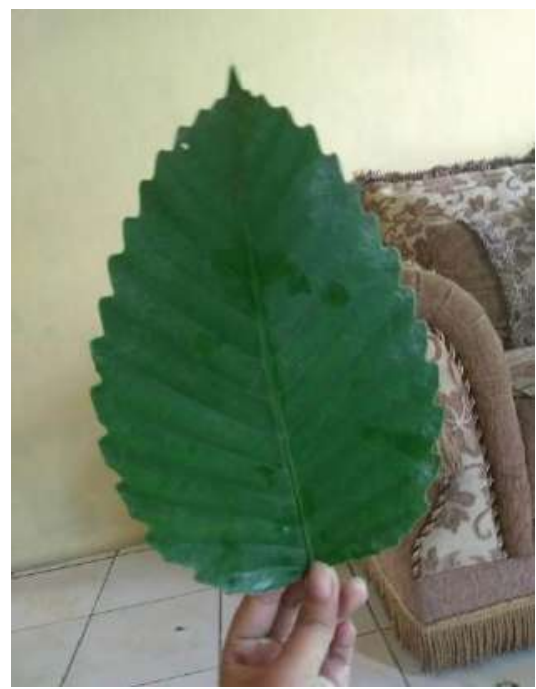

Sampel daun sempur 
LABORATORIUM PENGUJIAN / Analyses Laboratory DEPARTEMEN AGRONOMI DAN HORTIKUITURA, FAKULTAS PERTANIAN DEPARTEMEN INSTITUT PERIANIAN BOGOR / Bogor Agricultural University Kampus IPB Darmaga Jl. Meranti. Wing 9/Level 4, Bogor 16680 .

FRM $5.10-21-77$ SHP No.187/07/L/19

\title{
HASIL PENGUJIAN/RESULTS OF ANALYSIS
}

\begin{abstract}
Nomor Sertifikat/Certificate Number $\quad$ : 187/07/LL/19
Nama Sampel/Sample Name : : Tanaman

Jumlah Sampel/Sample amount $\quad$ : 22 sampel
\end{abstract}

\begin{tabular}{|c|c|c|c|c|}
\hline \multirow[t]{3}{*}{ Kode Laboratorium } & \multirow[t]{3}{*}{ Kode Konsumen } & Klorofil a (mg/g) & klorofil b (mg/g) & $\begin{array}{l}\text { total klorofil } \mathrm{a}+\mathrm{b} \\
\qquad(\mathrm{mg} / \mathrm{g})\end{array}$ \\
\hline & & \multicolumn{3}{|c|}{ Ekstrak: Accetone+ Tris Ha $1 \%$} \\
\hline & & \multicolumn{3}{|c|}{ Pengukuran : Spektrofometer U8-VIS } \\
\hline $1907149-1$ & Angsana & 3.33 & 1.81 & 5.14 \\
\hline $1907149-2$ & Aren & 4.19 & 2.4 & 6.59 \\
\hline $1907149 \cdot 3$ & Beringin & 1.33 & 0.69 & 2.02 \\
\hline $1907149-4$ & Bisbul & 1.36 & 0.74 & 2.1 \\
\hline $1907149-5$ & Bungur & 2.08 & 1.11 & 3.19 \\
\hline $1907149-6$ & cemara gembel & 1.21 & 0.59 & 1.8 \\
\hline $1907149-7$ & Cempaka & 2.3 & 1.38 & 3.68 \\
\hline $1907149-8$ & Damar & 1.3 & 0.82 & 2.12 \\
\hline $1907149-9$ & Flamboyan & 3.27 & 1.77 & 5.04 \\
\hline $1907149-10$ & Kapuk & 4.29 & 2.31 & 6.6 \\
\hline $1907149-11$ & Ketapang K & 2.76 & 1.46 & 4.22 \\
\hline $1907149-12$ & Kupu-kupu & 2.59 & 1.32 & 3.91 \\
\hline $1907149-13$ & Mahoni & 2.21 & 1.5 & 3.71 \\
\hline $1907149-14$ & Nangka & 2.52 & 1.46 & 3.98 \\
\hline $1907149-15$ & Palem Putri & 1.69 & 1 & 2.69 \\
\hline $1907149-16$ & Sempur & 0.31 & 1.36 & 1.67 \\
\hline $1907149-17$ & Tanjung & 3.25 & 1.89 & 5.14 \\
\hline $1907149-18$ & Walisongo & 2.52 & 1.37 & 3.89 \\
\hline $1907149-19$ & Palem phoenix & 1.81 & 0.21 & 2.02 \\
\hline $1907149-20$ & Mangga & 0.86 & 1.64 & 2.5 \\
\hline $1907149-21$ & Kenari & 1.23 & 1.57 & 2.8 \\
\hline
\end{tabular}

Manajer-Teknis/Technical Manager

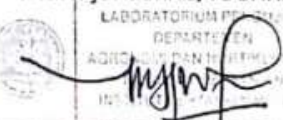

Dr. Dwi Guntoro, ISP, MSi

NIP. 197008291997031001

Hasil Pengujian hanya beriaku bagi contoh yang diuji /Results of analysis are valid only for the anatyzed samples. ered by the customer.

Sertifikat Hasil PenguTan tidok boleh disalin sebagian atou seluruhnya tanpa seगjin LP DAGH-IPB/No part of the certificate of anatysis is allowed to be reproduced without permission trom the anatysis loborator.

Lembar Hasil Penguilan merupakan bagion tok terpisahkan dari Sertifikat Hasli Pengujian ini/Results of analysis are included in this certificate of analysis. 


\section{RIWAYAT PENULIS}

Penulis dilahirkan di Bogor pada tanggal 25 Februari 1997. Penulis merupakan anak tunggal dari Dhoni Suhendra dan Sadiah. Penulis menyelesaikan pendidikan Taman Kanak-kanak hingga Sekolah Dasar di Sekolah Islam Terpadu Birrul Waliidain Kabupaten Bogor, kemudian menyelesaikan pendidikan Sekolah Menengah Pertama hingga Sekolah Menengah Atas di Kota Bogor pada tahun 2015 di SMP Negeri 6 Bogor, dan SMA Negeri 6 Kota Bogor. Pada tahun yang sama penulis diterima di Institut Pertanian Bogor (IPB) melalui jalur SNMPTN (Seleksi Nasional Masuk Perguruan Tinggi Negeri) di Departemen Arsitektur Lanskap, Fakultas Pertanian, Institut Pertanian Bogor.

$\frac{T}{d}$

Penulis menjadi pengurus BEM Faperta Kabinet Asa Karya selama periode 2016-2017 menjabat sebagai staff Departemen Seni dan Budaya. Selain itu, penulis juga aktif menjadi panitia dalam beberapa kegiatan BEM dan Himpunan Mahasiswa. Selain kegiatan akademis, penulis pernah mengikuti be berapa lomba diantaranya Sayembara Desain Lapangan Parkir Welcome Area Mekarsari dan Sayembara Desain Arsitektur Street Corridor.

Penulis mengabdikan dirinya sebagi Asisten mata kuliah Teknik Studio (ARL 210) pada tahun 2016-2017 dengan Koordinator Mata kuliahnya adalah Dr. If. Bambang Sulistyantara, M.Agr, Desain Lanskap (ARL 312) dengan Roordinator Mata kuliahnya Dr. Akhmad Arifin Hadi SP, M.ALa, serta mata kuliah Perawatan Tanaman Lanskap (ARL 324) dengan Koordinator Mata Kuliahnya Dr. Ir. Tati Budiarti M.Si. Penulis berhasil menyelesaikan penelitian yang berjudul "Evaluasi Fungsi Fisik dan Toleransi Poohon Tepi Jalan terhadap Polusi Udara di Lingkar Luar Kebun Raya Bogor" sebagai syarat menjadi sarjana pertanian dibawah bimbingan Dr. Ir. Bambang Sulistyantara, M.Agr. 